\title{
Mosselkweek en effecten op natuur
}

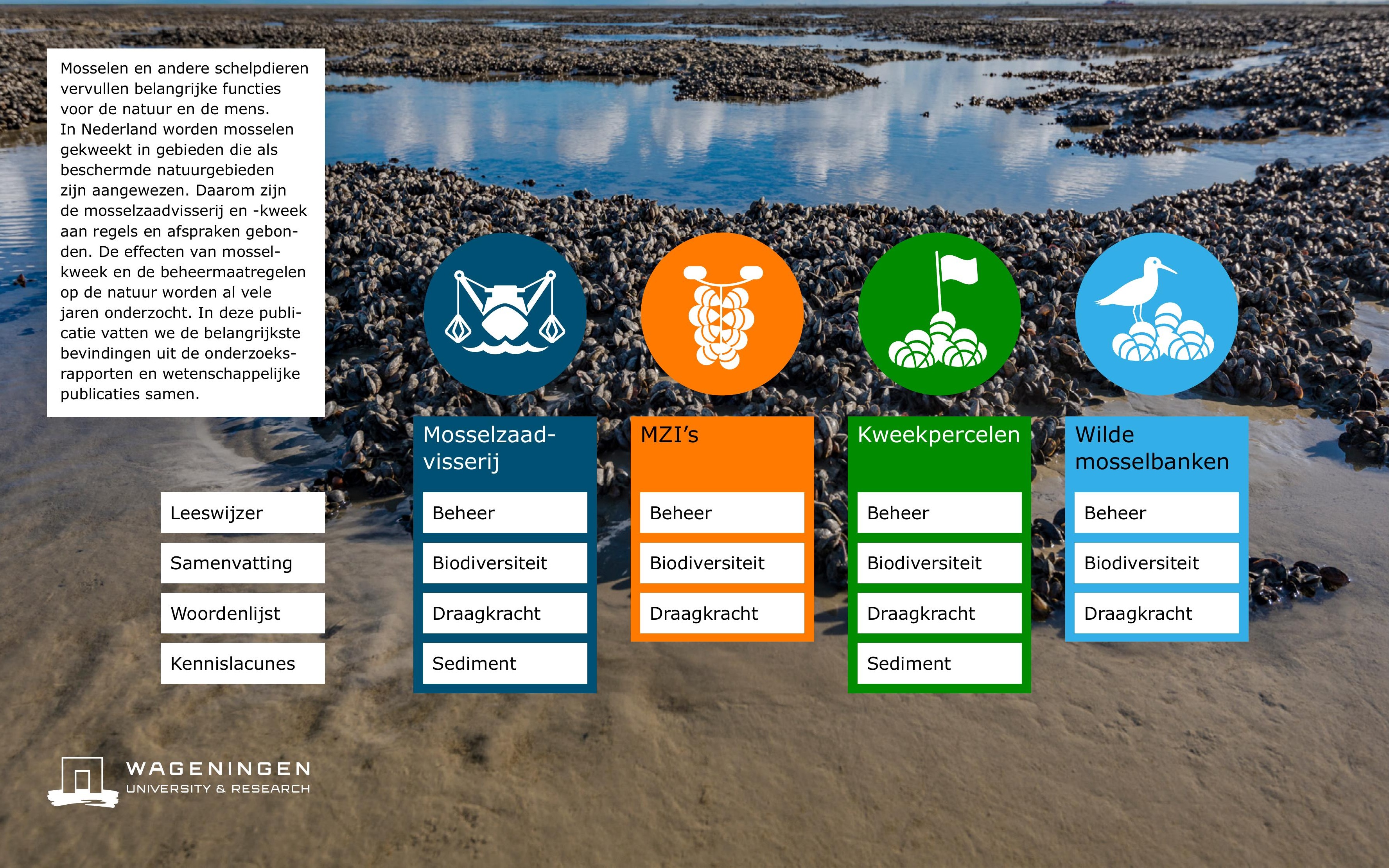




\section{Leeswijzer}

Deze interactieve PDF vat het onderzoek naar de relatie tussen natuur en mosselkweek in Waddenzee, Oosterschelde en Voordelta samen. Sinds 1990 worden de effecten van mosselvisserij en -kweek op natuur en ecologie intensief onderzocht. In de Inleiding vindt u meer informatie over de achtergronden van dit onderzoek.

\section{Navigatie interactieve pdf}

In deze interactieve pdf worden 4 thema's onderscheiden. De eerste drie gaan over het kweekproces zelf: mosselzaadvisserij, mosselzaadinvanginstallaties en kweekpercelen. Het vierde thema gaat over wilde mosselbanken. Ieder thema is vervolgens ingedeeld in een aantal hoofdonderwerpen. Hierbinnen kunt $u$ dan navigeren naar specifieke deelonderwerpen. De navigatie werkt alleen als u Acrobat Reader gebruikt. Cursief gedrukte woorden zijn opgenomen in de woordenlijst.

\section{Uitvergroten plaatjes}

Een aantal plaatjes in de interactieve pdf kunt $u$ uitvergroten door er op te klikken. $U$ kunt zien of dit mogelijk is als er een plus-teken verschijnt als u met uw muis op het plaatje klikt. Deze plaatjes zijn ook steeds op een aparte pagina weergegeven en te benaderen via de navigatiepijlen.

\section{Uitprinten interactieve pdf}

Deze publicatie is ontwikkeld om te lezen vanaf een beeldscherm en makkelijk te kunnen navigeren tussen thema's en (deel)onderwerpen die uw interesse hebben. Het is ook mogelijk de interactieve pdf uit te printen of om er op het beeldscherm op de traditionele manier doorheen te scrollen. In dat geval moet $u$ er rekening mee houden dat sommige teksten meerdere keren te zien zijn, omdat zij onder meerdere thema's in de navigatie terugkomen.

\section{Algemeen}

\section{Leeswijzer}

\section{Samenvatting}

\section{Woordenlijst}

\section{Inleiding}

\section{Kennislacunes}

\section{Literatuurlijst}

\section{Colofon}

Hoe wordt de mosselzaadvisserij gereguleerd?
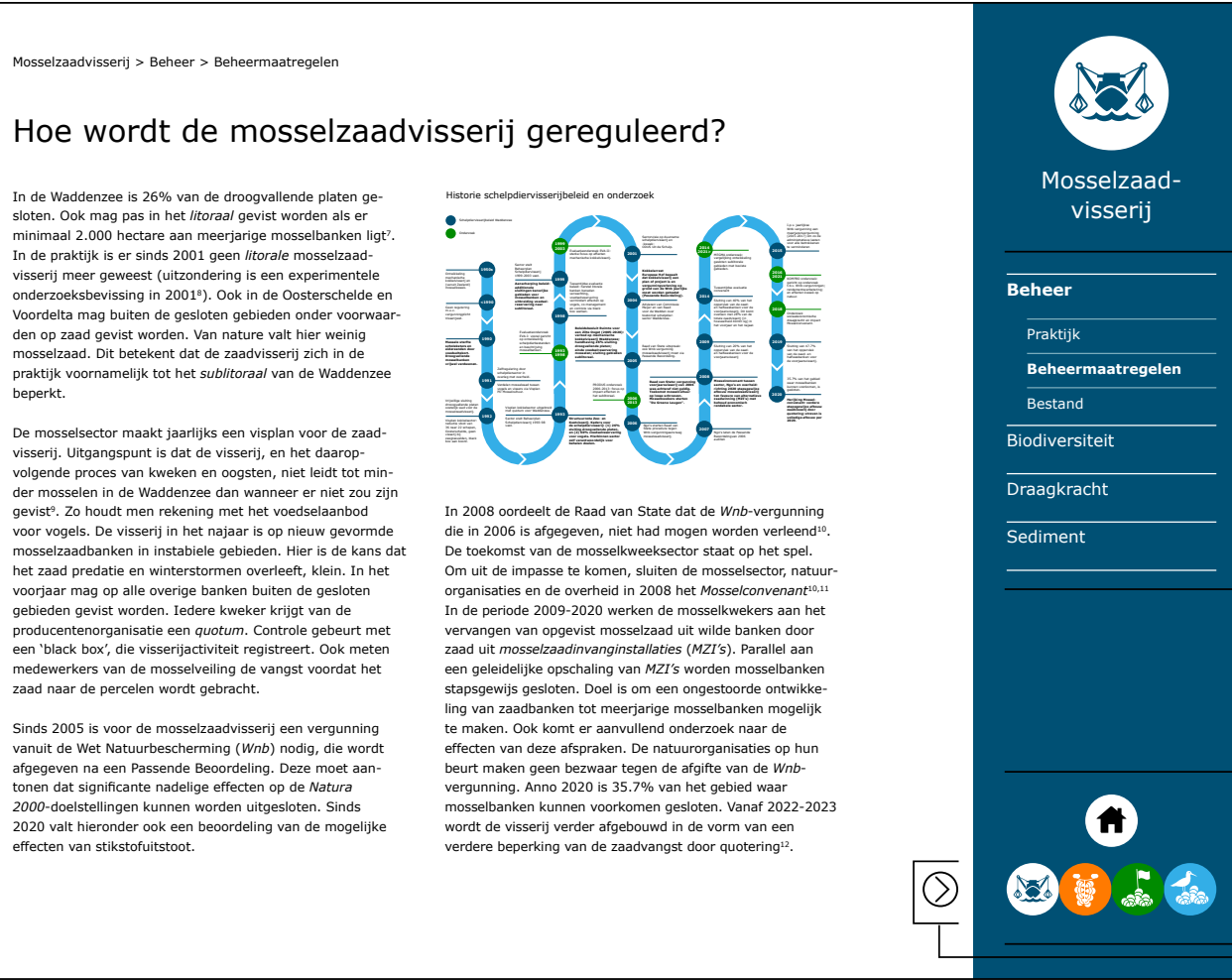

Menu

$U$ kunt via het menu door het onderdeel navigeren en klikken op de gewenste (deel)onderwerpen.

\section{Iconen}

$U$ kunt vanaf elke pagina met de icoontjes navigeren naar de verschillende onderdelen van het mosselkweekproces of het onderwerp wilde mosselbanken. Door op het huisje te klikken keert $\mathrm{u}$ terug naar de eerste pagina van de pdf.

Navigatiepijlen

Als een deelonderwerp uit meerdere pagina's bestaat, kunt u met de navigatiepijl binnen het onderwerp navigeren.

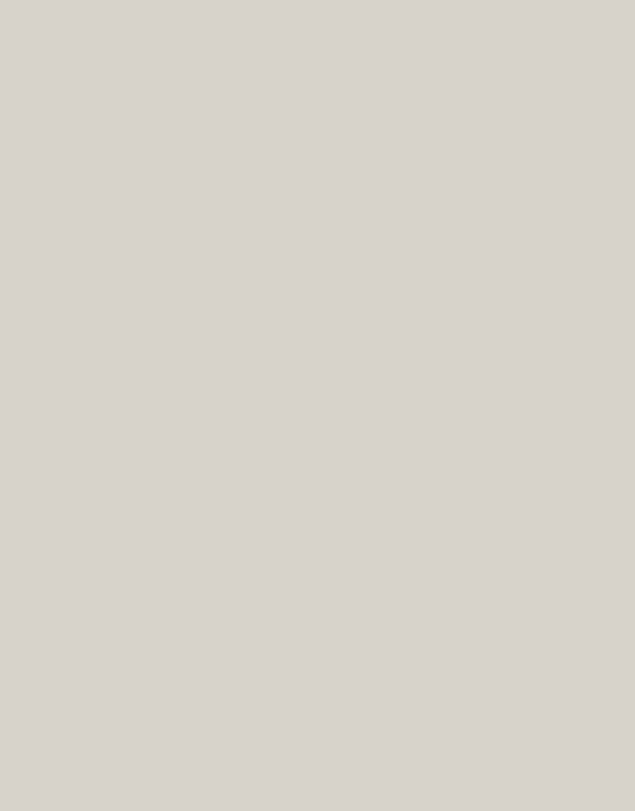




\section{Samenvatting}

De Waddenzee, Oosterschelde en Voordelta zijn beschermde natuurgebieden. De mosselvisserij- en kweek worden daarom gereguleerd. In het Mosselconvenant hebben sector, natuurorganisaties en overheid afspraken gemaakt over onder andere de stapsgewijze afbouw van mosselzaadvisserij op de bodem naar mosselzaadinvanginstallaties in de waterkolom. Doel is een ongestoorde ontwikkeling van zaadbanken tot meerjarige mosselbanken mogelijk te maken. $\mathrm{Er}$ is veel onderzoek gedaan naar de effecten van het schelpdiervisserijbeheer. Deze publicatie vat het onderzoek naar de relatie tussen natuur en mosselkweek samen.

\section{Wilde mosselbanken en kweekpercelen hotspots voor} biodiversiteit

Mosselbanken en kweekpercelen vormen leefgebieden voor soorten op en in de bodem. Beiden hebben een hoge biodiversiteit. Hoe meer mosselen, hoe meer andere soorten.

\section{Meerjarige wilde mosselbanken in gesloten droog-} vallend gebied Waddenzee hersteld

In de jaren ' 90 zijn delen van droogvallende platen gesloten voor bodemberoerende visserij. In de praktijk is er vanaf 2002 in het hele droogvallende gebied geen mosselzaadvisserij meer geweest. In de Waddenzee heeft het oppervlak droogvallende mosselbanken zich hersteld tot waarden van voor het dieptepunt begin jaren ' 90 . Welke rol het langdurig niet bevissen heeft gespeeld in dit herstel, is niet na te gaan. In de Oosterschelde komen geen droogvallende banken voor.
Na vijf jaar geen wezenlijk andere bodemgemeenschap in gesloten sublitoraal gebied Waddenzee In de periode 2006-2012 zijn delen van een sublitorale (onder water liggende) mosselbank gesloten voor mosselvisserij terwijl andere delen bevist mochten worden. Direct na bevissing is de dichtheid aan mosselen en andere soorten op beviste delen lager. Na 1,5 jaar zijn er geen verschillen meer met onbeviste delen.

In 2014 zijn enkele sublitorale gebieden volledig gesloten voor bodemberoerende visserij. Vijf jaar na sluiting ziet hier de bodemdiergemeenschap er niet duidelijk anders uit in vergelijking met de gebieden waar wel gevist wordt. Als er verschillen worden gevonden, komt dit door de gebiedskeuze; juist soortenrijke gebieden zijn gesloten.

\section{Mosselproductie niet gepaard met vertroebeling}

Mosselkweek zorgt voor meer mosselen in de Waddenzee. Zij filteren continu zwevend materiaal uit de waterkolom. Hierdoor wordt het water helderder en verbetert de waterkwaliteit. De troebelheid van het water kan lokaal sterk toenemen als de mosselen worden opgevist. Dit is tijdelijk, het positieve effect van filtratie is continu.

\section{Draagkracht Waddenzee en Oosterschelde voor} schelpdieren niet onder druk

Schelpdieren voeden zich door microalgen uit het water te filteren. Bij een te groot schelpdierbestand kan de groei van deze algen worden afgeremd (overbegrazing). Momentee lijkt de draagkracht voor schelpdieren van Waddenzee en Oosterschelde niet onder druk te staan.
Algemeen

Leeswijzer

\section{Samenvatting}

Woordenlijst

\section{Inleiding}

\section{Kennislacunes}

\section{Literatuurlijst}

\section{Colofon}




\section{Woordenlijst}

Biodiversiteit: Soortenrijkdom; de verscheidenheid van aanwezige soorten en de (genetische) variatie hierbinnen.

Biomassa: De hoeveelheid levende organismen in een bepaalde levensgemeenschap (bijvoorbeeld mosselen) uitgedrukt in gewicht.

Draagkracht: de hoeveelheid schelpdieren die een ecosysteem kan produceren zonder dat dit een negatief effect heeft op de beschikbare hoeveelheid voedsel voor filtrerende organismen, zoals schelpdieren.

Ecosysteemdiensten: functies die (in dit geval) schelpdieren hebben voor de natuur en voor de mens. Voorbeelden: leefgebied voor andere dieren, voedselbron voor dieren en mensen, verbeteren waterkwaliteit door filtratie, bieden van werkgelegenheid, onderdeel van cultuurhistorie van kustgemeenschappen.

Geassocieerde soorten: Soorten die op en tussen de mosselen op wilde mosselbanken en kweekpercelen leven. Bijvoorbeeld: andere schelpdieren, krabbetjes, zeesterren, sponzen, anemonen, pokken en wormen.

Graasdruk: Het wegfilteren van voedsel door schelpdieren. Kweekrendement: De hoeveelheid consumptiemosselen die uit een kilo zaad komt.

Litora(a)l(e): Droogvallende platen (hier: in de Waddenzee en Oosterschelde); het deel dat met eb droogvalt.

Microalgen: Microscopische algen die voorkomen in zoet en zout water. Ze zijn doorgaans eencellig en hebben geen wortels, stengels of bladeren.

Mosselconvenant: Meerjarige afspraken tussen de mosselsector, natuurorganisaties en overheid over onder andere de stapsgewijze afbouw van de mosselzaadvisserij richting het gebruik van Mosselzaadinvanginstallaties. Doel is om een ongestoorde ontwikkeling van zaadbanken tot meerjarige mosselbanken mogelijk te maken. De afspraken zijn gemaakt in 2008 en herijkt in 2020.
Mosselzaadinvanginstallaties (MZI's): Drijvers (boeien, buizen) met daaraan substraat in de vorm van touwen of netten. Mossellarven die in het water drijven, kunnen zich in het voorjaar en de vroege zomer aan dit substraat hechten.

Natura 2000: Gebieden aangewezen onder de Europese Vogelrichtlijn en onder de Habitatrichtlijn.

Overbegrazing: De situatie waarin schelpdieren zoveel micro-algen eten dat de groei (aanwas) van de algen wordt afgeremd.

(Pseudo)feces: De nep-ontlasting van mosselen (en andere tweekleppige schelpdieren en weekdieren die zich door filtratie voeden). De mosselen filteren water. De microalgen worden opgenomen als voedsel. Deeltjes uit het water die niet kunnen worden opgenomen (bijvoorbeeld slib) worden ingepakt in mucus en uit het lichaam 'gepoept' zonder dat ze langs het spijsverteringskanaal zijn geweest.

Quotum: De maximale hoeveelheid mosselzaad die jaarlijksdoor de kwekers mag worden geoogst. Dit wordt gebaseerd op de jaarlijkse inventarisatie van het mosselbestand.

Schaduwwerking: Lokale voedseltekorten voor mosselen die kunnen optreden binnen of in nabijheid van mosselzaadinvanginstallaties.

Sublitora(a)l(e): Het deel van (hier) de Waddenzee en Oosterschelde dat altijd onder water staat.

Wnb: Wet natuurbescherming

Zaadval: De hoeveelheid mossellarven die tot zaad uitgroeien. Uit de zaadval worden jonge mosselen geboren.

\section{Algemeen}

\section{Leeswijzer}

Samenvatting

\section{Woordenlijst}

\section{Inleiding}

\section{Kennislacunes}

\section{Literatuurlijst}

\section{Colofon}




\section{Inleiding}

Mosselen en andere schelpdieren vervullen belangrijke functies voor de natuur en de mens. Zo vormen ze leefgebieden voor andere dieren, zijn ze een voedselbron voor dieren en mensen, dragen ze bij aan de waterkwaliteit, bieden ze werkgelegenheid en zijn ze onderdeel van de cultuur van kustgemeenschappen. Dit zijn maar een paar voorbeelden van functies die we gezamenlijk ecosysteemdiensten noemen ${ }^{1,2}$

In Nederland zijn de Waddenzee en de Oosterschelde de belangrijkste gebieden waar mosselen van nature voorkomen en worden gekweekt. Deze gebieden zijn beschermde natuurgebieden (o.a. Natura 2000). Daarom zijn de mosselzaadvisserij en -kweek aan regels en afspraken gebonden. Op die manier wordt een balans gezocht tussen de verschillende ecosysteemdiensten rond enerzijds natuur en ecologie en anderzijds economie en cultuurhistorie. De Nederlandse mosselzaadvisserij - en kweek en de mosselhangcultures zijn onafhankelijk gecertificeerd volgens de Marine Stewardship Council standaard voor duurzame en goed beheerde visserij ${ }^{3,4}$.

Sinds de jaren '90 is er veel onderzoek gedaan naar de effecten van mosselvisserij- en kweek op natuur en ecologie. Dit leidde tot aanpassingen in het schelpdiervisserijbeleid, en tot nieuwe afspraken tussen de mosselsector, overheid en maatschappelijke organisaties. De effecten van het nieuwe beleid en beheerafspraken werden ook weer onderzocht. In deze publicatie vatten we de belangrijkste bevindingen uit de onderzoeksrapporten en wetenschappelijke publicaties samen. Hoe werkt de schelpdiervisserij en -kweek in de praktijk en hoe wordt deze gereguleerd? Wat weten we over de effecten van schelpdiervisserij- en kweek op de natuur? En welke vragen staan nog open?
Naast het reguleren van visserij kent het beheer gericht op natuurbescherming ook een ander aspect: 'de natuur een handje helpen' door bijvoorbeeld mosselbanken aan te leggen. Dit onderdeel valt buiten de reikwijdte van deze publicatie, en is elders samengevat ${ }^{5,6}$.

Deze publicatie is interactief, zodat u snel kunt navigeren tussen onderwerpen van uw keuze. Uitleg hierover is opgenomen in de Leeswijzer.

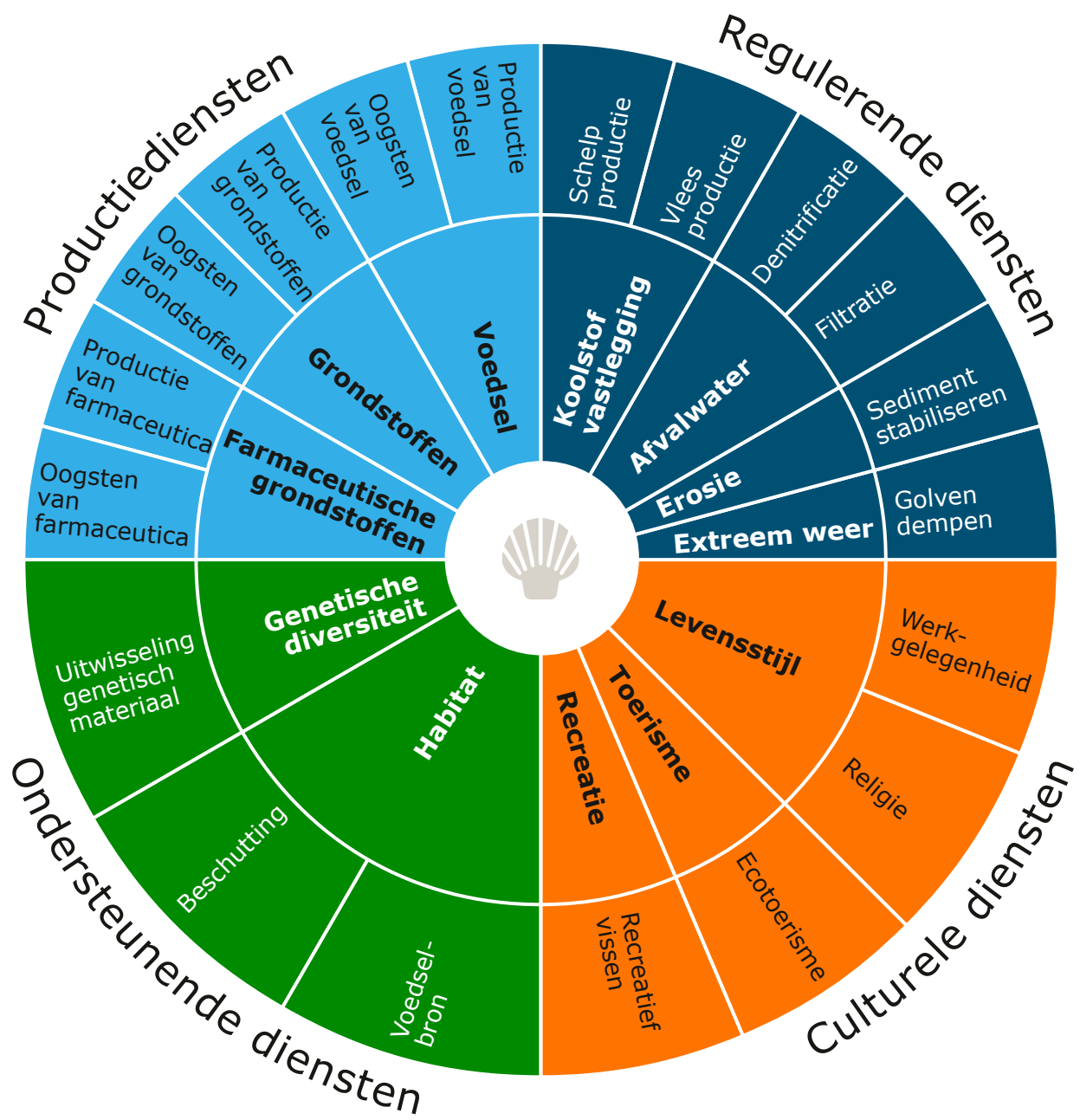

Bron: Figuur 1 vertaald uit 1
Algemeen

\section{Leeswijzer}

Samenvatting

\section{Woordenlijst}

\section{Inleiding}

\section{Kennislacunes}

\section{Literatuurlijst}

Colofon

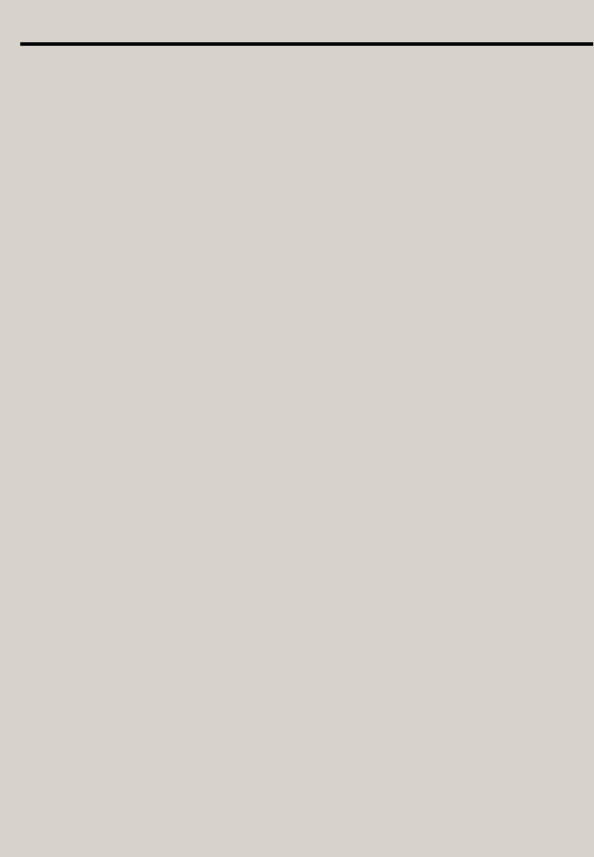




\section{Wat is mosselzaadvisserij?}

Het kweken van mosselen begint bij het mosselzaad. Mosselkwekers vissen het zaad op uit wilde mosselbanken op de zeebodem, of vangen ze op uit de waterkolom met mosse/zaadinvanginstallaties ( $M Z I^{\prime} s$ ). Het vissen gebeurt vooral in de Waddenzee, maar soms ook in de Oosterschelde of Voordelta. Het inwinnen van zaad met MZI's gebeurt vooral in de Waddenzee en Oosterschelde. De mosselzaadvisserij vindt in het voorjaar en het najaar plaats, en is aan regels gebonden. Wilde mosselen vormen namelijk mosselbanken. Deze banken vormen weer een leefgebied voor veel andere soorten. Mosselbanken hebben daarmee een belangrijke functie voor de natuur. Ze dragen bij aan een hoge biodiversiteit en zijn een belangrijke schakel in het voedselweb.
Veel mosselzaadbanken verdwijnen gedurende de eerste winter door natuurlijke processen. Voorbeelden zijn consumptie door zeesterren en wegspoeling door stroming of stormen. De mosselzaadvisserij richt zich daarom in eerste instantie op zaadbanken waarvan verwacht wordt - op basis van historische kennis en de actuele toestand - dat zij weer snel zullen verdwijnen. De visserij in het najaar gebeurt zo snel mogelijk nadat het mosselbestand in kaart is gebracht. Zo wordt verlies van zaad door stormen of vraat door zeesterren zoveel mogelijk voorkomen.

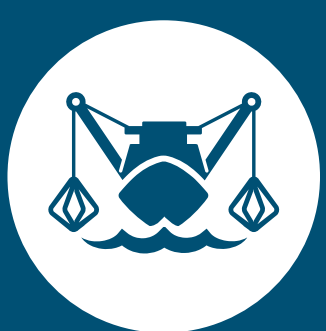

Mosselzaadvisserij

\section{Beheer}

Praktijk

Beheermaatregelen

Bestand

Biodiversiteit

Draagkracht

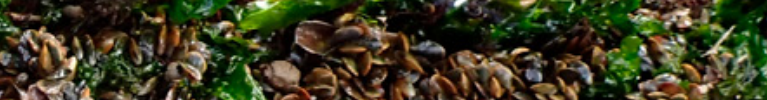

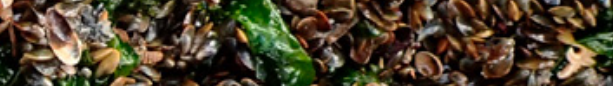
1) 402 , 4 ,

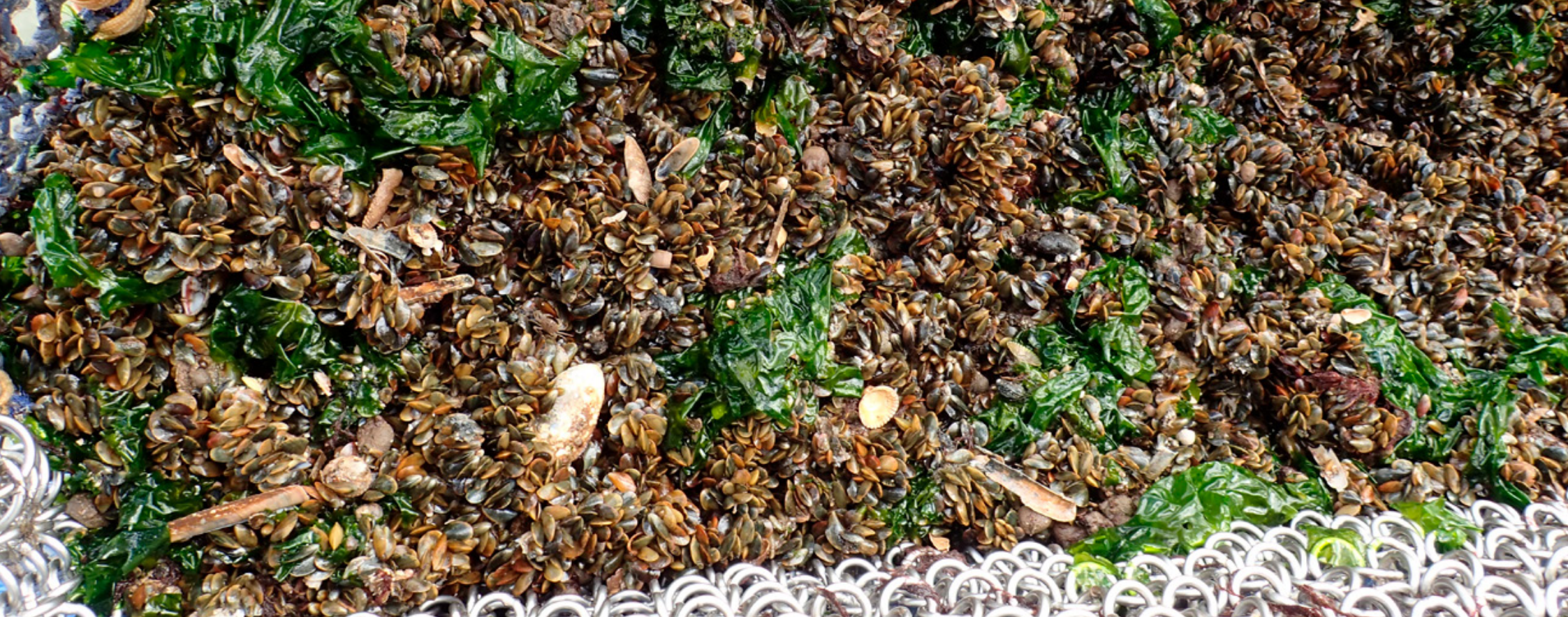

Sediment

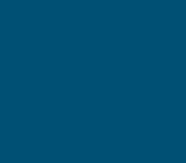

주잉 3 


\section{Hoe wordt de mosselzaadvisserij gereguleerd?}

In de Waddenzee is $26 \%$ van de droogvallende platen gesloten. Ook mag pas in het litoraal gevist worden als er minimaal 2.000 hectare aan meerjarige mosselbanken ligt?. In de praktijk is er sinds 2001 geen litorale mosselzaadvisserij meer geweest (uitzondering is een experimentele onderzoeksbevissing in $2001^{8}$ ). Ook in de Oosterschelde en Voordelta mag buiten de gesloten gebieden onder voorwaarden op zaad gevist worden. Van nature valt hier weinig mosselzaad. Dit betekent dat de zaadvisserij zich in de praktijk voornamelijk tot het sublitoraal van de Waddenzee beperkt.

De mosselsector maakt jaarlijks een visplan voor de zaadvisserij. Uitgangspunt is dat de visserij, en het daaropvolgende proces van kweken en oogsten, niet leidt tot minder mosselen in de Waddenzee dan wanneer er niet zou zijn gevist ${ }^{9}$. Zo houdt men rekening met het voedselaanbod voor vogels. De visserij in het najaar is op nieuw gevormde mosselzaadbanken in instabiele gebieden. Hier is de kans dat het zaad predatie en winterstormen overleeft, klein. In het voorjaar mag op alle overige banken buiten de gesloten gebieden gevist worden. Iedere kweker krijgt van de producentenorganisatie een quotum. Controle gebeurt met een 'black box', die visserijactiviteit registreert. Ook meten medewerkers van de mosselveiling de vangst voordat het zaad naar de percelen wordt gebracht.

Sinds 2005 is voor de mosselzaadvisserij een vergunning vanuit de Wet Natuurbescherming (Wnb) nodig, die wordt afgegeven na een Passende Beoordeling. Deze moet aantonen dat significante nadelige effecten op de Natura 2000-doelstellingen kunnen worden uitgesloten. Sinds 2020 valt hieronder ook een beoordeling van de mogelijke effecten van stikstofuitstoot.
Historie schelpdiervisserijbeleid en onderzoek

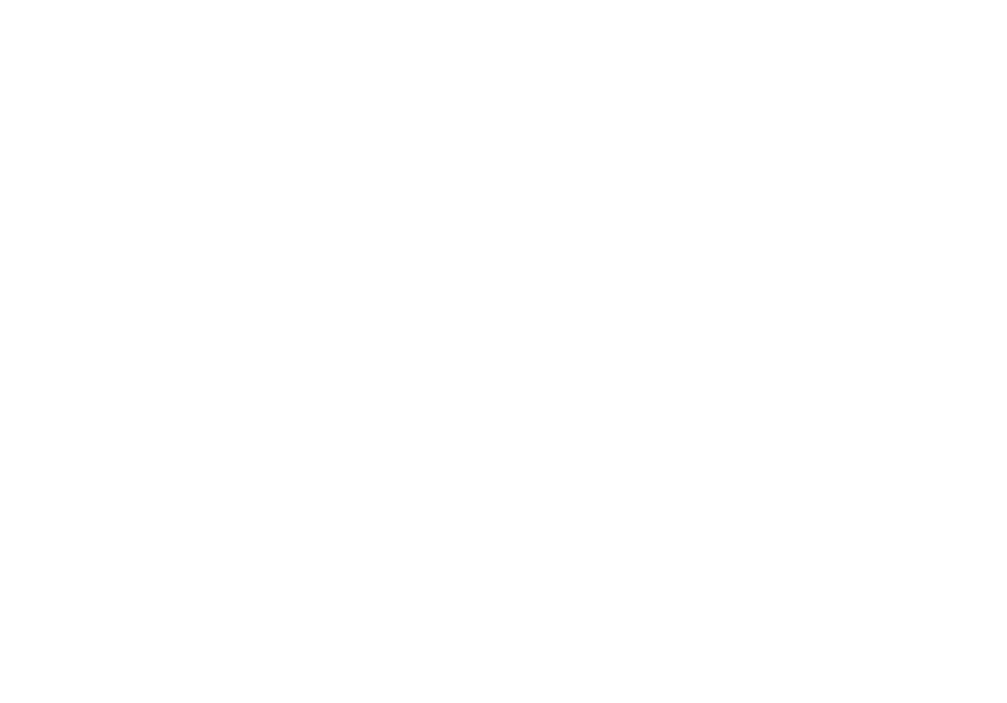

In 2008 oordeelt de Raad van State dat de Wnb-vergunning die in 2006 is afgegeven, niet had mogen worden verleend ${ }^{10}$ De toekomst van de mosselkweeksector staat op het spel. Om uit de impasse te komen, sluiten de mosselsector, natuurorganisaties en de overheid in 2008 het Mosselconvenant ${ }^{10,1}$ In de periode 2009-2020 werken de mosselkwekers aan het vervangen van opgevist mosselzaad uit wilde banken door zaad uit mosselzaadinvanginstallaties (MZI's). Parallel aan een geleidelijke opschaling van MZI's worden mosselbanken stapsgewijs gesloten. Doel is om een ongestoorde ontwikkeling van zaadbanken tot meerjarige mosselbanken mogelijk te maken. Ook komt er aanvullend onderzoek naar de effecten van deze afspraken. De natuurorganisaties op hun beurt maken geen bezwaar tegen de afgifte van de Wnbvergunning. Anno 2020 is $35.7 \%$ van het gebied waar mosselbanken kunnen voorkomen gesloten. Vanaf 2022-2023 wordt de visserij verder afgebouwd in de vorm van een verdere beperking van de zaadvangst door quotering ${ }^{12}$.
Mosselzaad-

visserij

\section{Beheer}

Praktijk

Beheermaatregelen

Bestand

\section{Biodiversiteit}

\section{Draagkracht}

\section{Sediment}

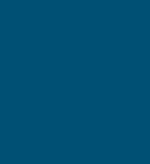


Historie schelpdiervisserijbeleid en onderzoek
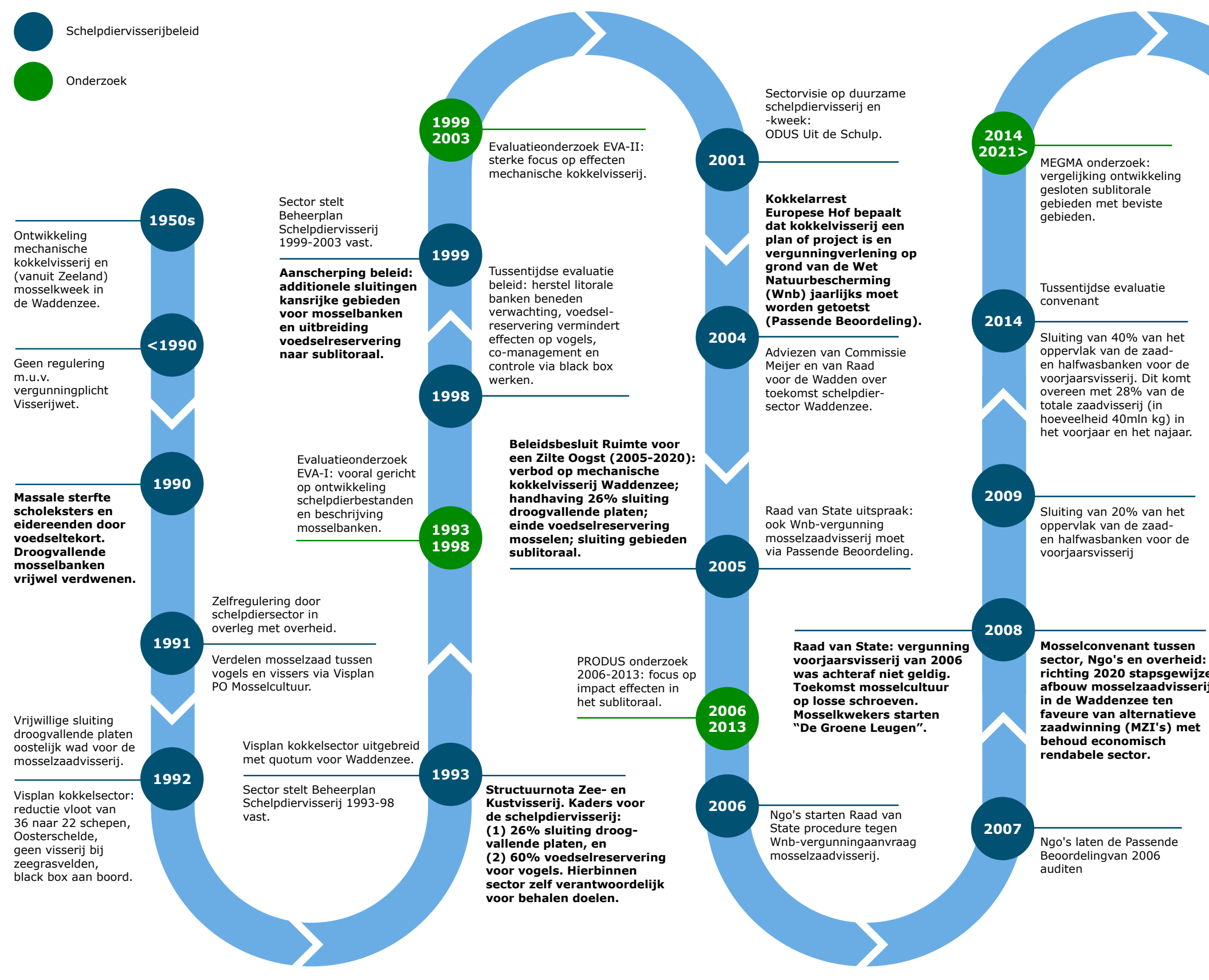

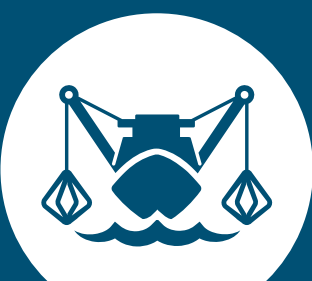

Mosselzaadvisserij

\section{Beheer}

Praktijk

Beheermaatregelen

Bestand

Biodiversiteit

Draagkracht

Sediment

(i)

() 


\section{Hoeveel mosselzaad ligt er in het sublitoraal van de Waddenzee?}

Mosselzaad-

visserij

De visserij op mosselzaad concentreert zich in het deel van de Waddenzee dat altijd onder water staat (sublitoraal). Ieder jaar brengt Wageningen Marine Research in opdracht van het ministerie van Landbouw, Natuur en Voedselkwaliteit de schelpdierbestanden in alle Nederlandse kustwateren in kaart $^{13}$. Hieronder vallen ook de mosselpopulaties in het sublitoraal van de Waddenzee. De jaarlijkse inventarisatie loopt al vanaf 1992. Hierdoor is er een lange tijdsreeks die een goed beeld geeft van de ontwikkeling van het sublitorale mosselbestand ${ }^{13-15}$. Daarnaast worden in opdracht van de mosselsector mosselzaadinventarisaties uitgevoerd. Deze inventarisaties in het voorjaar ${ }^{15}$ en in het najaar ${ }^{16}$ zijn bedoeld om besluiten te nemen over waar en hoeveel zaad de kwekers mogen vissen voor verdere uitgroei op de

Het bestand op de wilde mosselbanken in het sublitoraal is door natuurlijke omstandigheden aan fluctuaties onderhevig. In sommige jaren vindt vrijwel geen zaadval plaats, en in sommige jaren is er juist een massale zaadval. Vanaf de start van het jaarlijkse onderzoek in 1992 fluctueert het bestand aan zaad op de sublitorale wilde mosselbanken van de westelijke Waddenzee tussen de 0 en 93 miljoen kilo versgewicht (inclusief schelp), ten tijde van de voorjaarsvisserij. Dit betekent dat de kwekers in sommige jaren niet of maar heel weinig mosselzaad mogen oogsten. Door de introductie van mosselzaadinvanginstallaties (MZI's) zijn de kwekers minder afhankelijk van de wilde mosselzaadbestanden ${ }^{17}$

kweekpercelen.

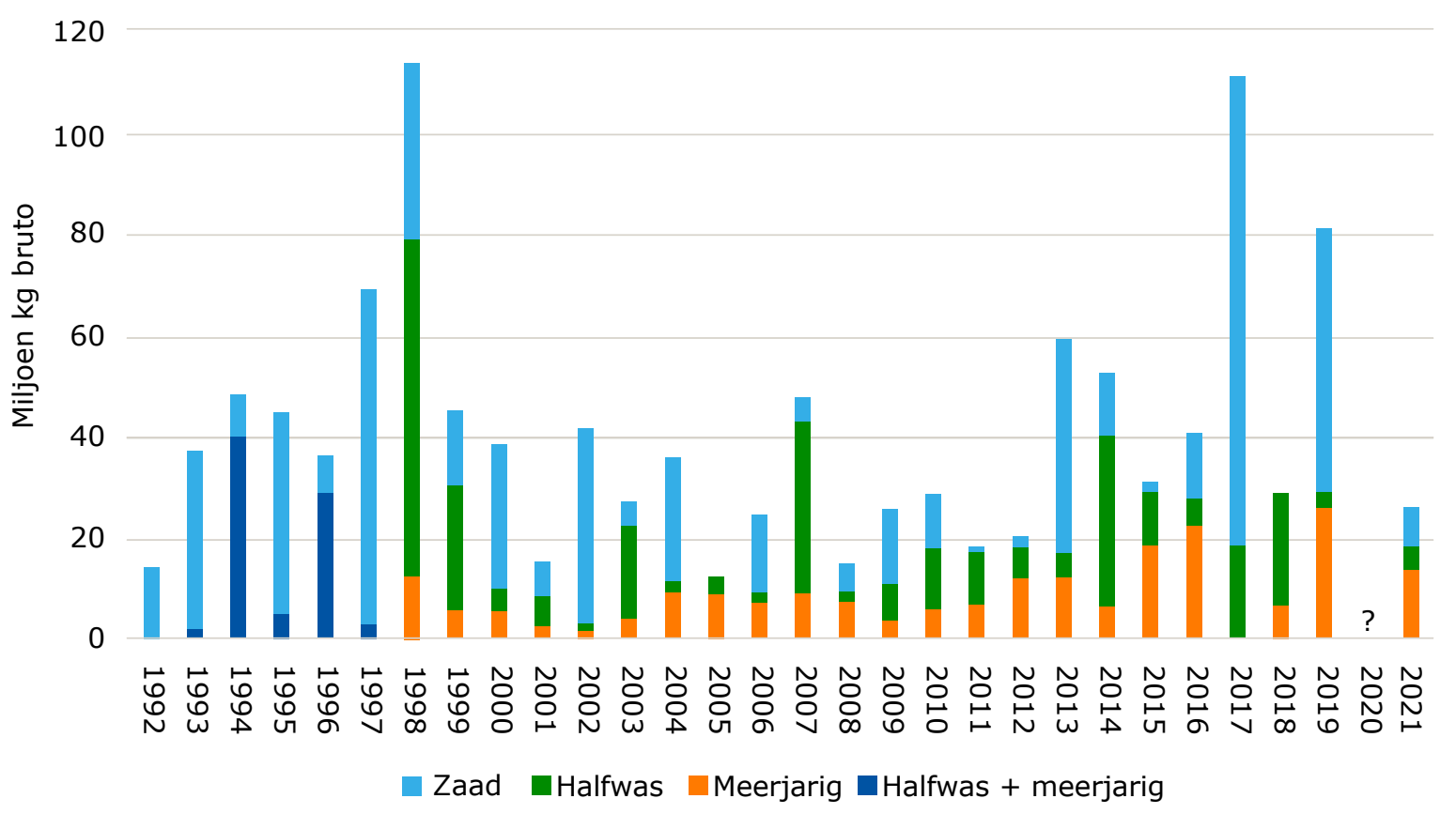

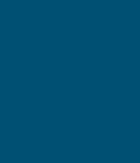

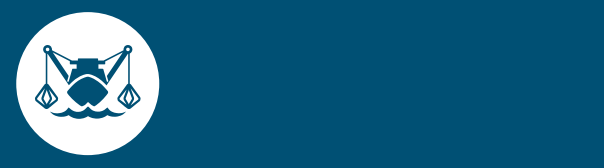




\section{Waarom zijn wilde mosselbanken belangrijk?}

Wilde mosselbanken spelen een belangrijke rol in het ecosysteem. Ze vormen structuren en leefruimte voor andere soorten, die op en tussen de mosselen leven ${ }^{32-34}$. Denk bijvoorbeeld aan andere schelpdieren, krabbetjes, zeesterren, sponzen, anemonen, pokken en wormen. Dit worden ook wel geassocieerde soorten genoemd. Ook leveren wilde mosselbanken voedsel voor schelpdieretende vogels en vogels die leven van organismen die in de mosselbanken voorkomen ${ }^{35-37}$. Mosselbanken zijn dus van groot belang voor de biodiversiteit, en vormen een belangrijke schakel in het voedselweb ${ }^{6,38}$. Mosselen op kweekpercelen vervullen grotendeels dezelfde rol als mosselen op wilde banken ${ }^{32}$.

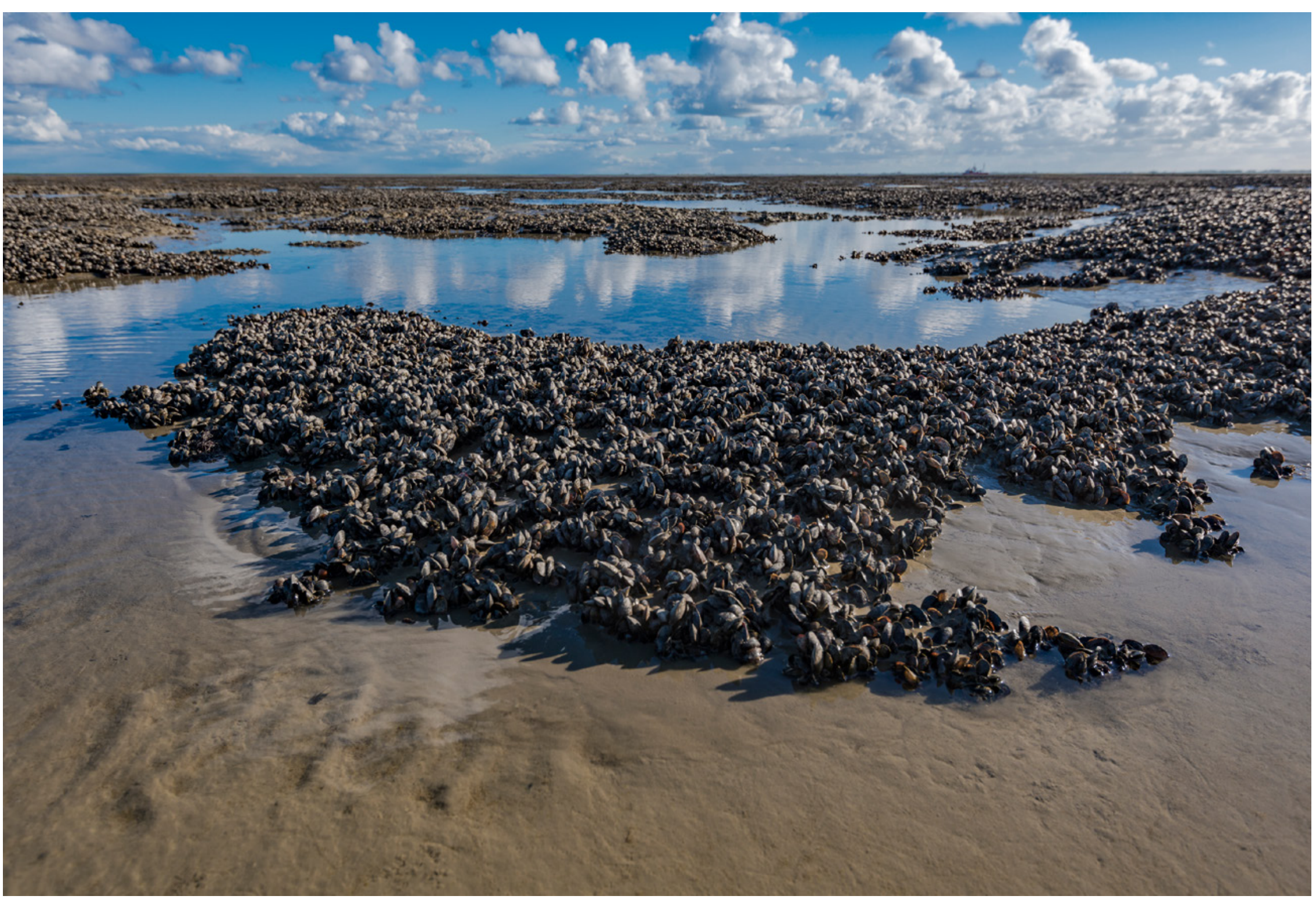

Mosselzaadvisserij

Beheer

\section{Biodiversiteit}

Rol mosselbanken

Ontwikkeling

sublitorale banken

\section{Samenstelling}

bodemdieren

Visserijeffecten

bodemdieren

Gebiedssluiting

sublitoraal

Draagkracht

Sediment

(i)

80 


\section{Hoe ontwikkelt het areaal aan sublitorale mosselbanken zich?}

\section{Mosselzaad-}

visserij

Sinds 1992 worden mosselen in het sublitoraal van de westelijke Waddenzee jaarlijks tweemaal geïnventariseerd, in het voorjaar en in het najaar ${ }^{13}$. Met deze gegevens worden ieder jaar verspreidingskaarten gemaakt. Uit een vergelijking van de jaarlijkse verspreidingskaarten blijkt in welke gebieden vaak mosselzaad valt, en in welke gebieden dit mosselzaad vaak wel, of juist niet, overleeft. Deze informatie is verwerkt in de zogeheten "ervaringskaart" (stabilititeitskaart). In deze kaart is ook veldexpertise van vissers, visserijkundig ambtenaren en onderzoekers verwerkt. De kaart laat zien in welke gebieden de kans dat mosselzaad de eerste winter overleeft, als hoog of juist laag wordt ingeschat. De kaart wordt gebruikt als basis voor de mosselzaadvisserij in het najaar, wanneer op instabiele banken gevist mag worden.

Omdat sublitorale mosselbanken nooit droog komen te liggen, is kartering van de precieze contouren veel moeilijker dan in het litoraal. De contouren worden ingeschat op basis van de vangsten per monsterpunt. In de voorjaarsinventarisatie wordt deze kartering sinds 2014 structureel jaarlijks uitgevoerd. Het doel is om de ontwikkeling van arealen in de voor mosselvisserij (en garnalenvisserij) gesloten gebieden te kunnen vergelijken met de gebieden waar nog steeds gevist mag worden ${ }^{45}$.

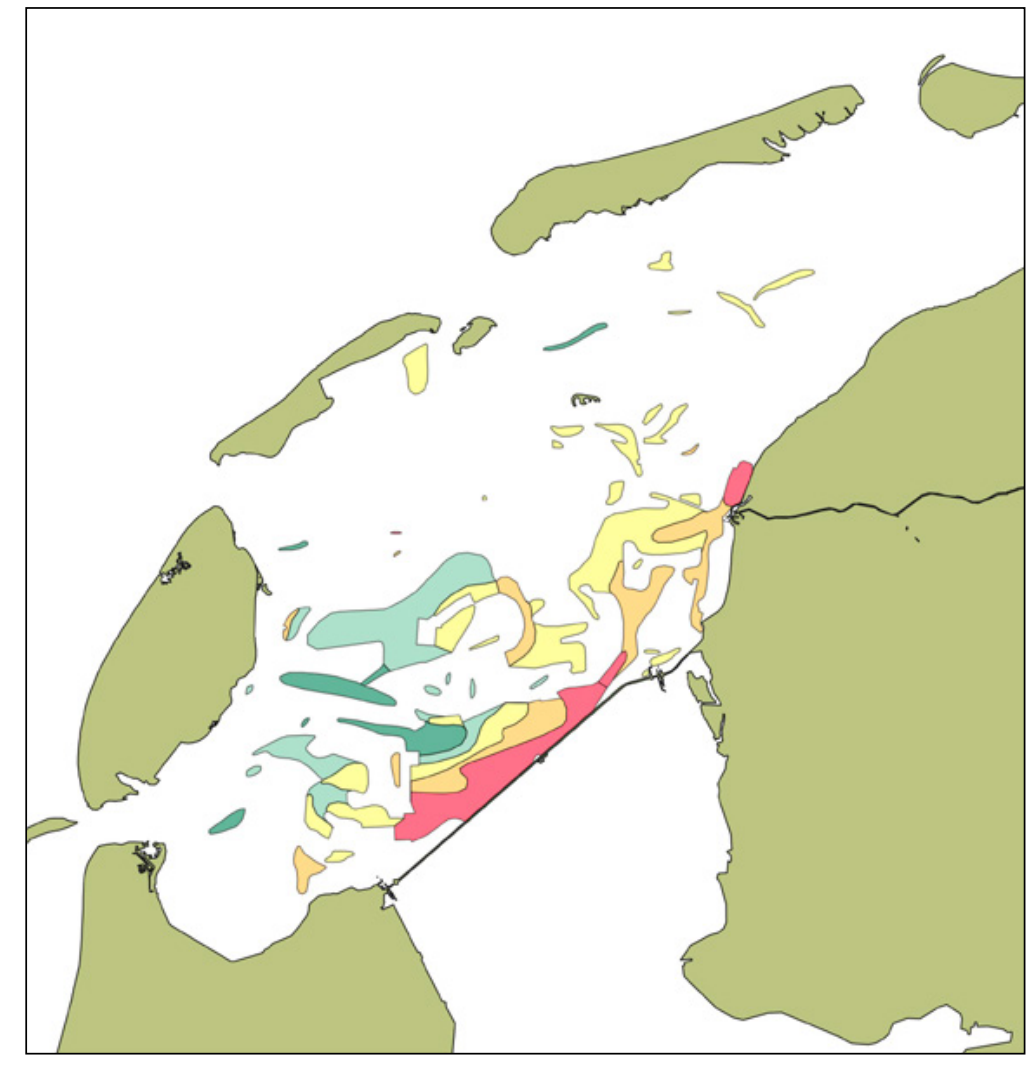

Stabiliteitskaart op basis van ervaring en expert judgement. Groen $=$ klasse $1=$ relatief instabiel; Lichtgroen $=$ klasse 2 ; Geel $=$ klasse 3 ; Oranje $=$ klasse 4 ; Rood $=$ klasse $5=$ relatief stabiel. ${ }^{.7}$

\section{Beheer}

\section{Biodiversiteit}

Rol mosselbanken

\section{Ontwikkeling} sublitorale banken

Samenstelling bodemdieren

Visserijeffecten bodemdieren

Gebiedssluiting sublitoraal

\section{Draagkracht}

\section{Sediment}

\section{(4)} ook al snel weer ${ }^{45}$. Het areaal sublitorale banken laat daardoor in de open gebieden een veel grilliger verloop zien.
Omdat de gesloten gebieden juist op plekken zijn gekozen waar zich in het verleden vaker meerjarige mosselbanken bevonden, is het areaal in de gesloten gebieden relatief stabiel. In de open gebieden worden na omvangrijke broedvallen grote arealen aan zaadbanken aangetroffen (zoals in 2017 en 2019). Hiervan verdwijnt echter een groot deel vaak 


\section{Zijn er verschillen in de bodemdierengemeenschap op wilde mosselbanken en op de kweekpercelen?}

De mosselen op de kweekpercelen spelen grotendeels dezelfde rol als op wilde mosselbanken; ze dragen bij aan een hoge biodiversiteit, verbeteren de waterkwaliteit, en bepalen gezamenlijk de draagkracht voor schelpdieren van het ecosysteem.

De biodiversiteit op mosselkweekpercelen verschilt niet wezenlijk van die op sublitorale mosselbanken. Beide hebben een relatieve hoge biodiversiteit. Op de wilde mosselbanken in het sublitoraal zijn in een grootschalige studie gemiddeld 84 verschillende soorten aangetroffen; op de percelen gemiddeld $102^{32}$. Er zijn twee verklaringen voor het verschil in aantallen soorten. Ten eerste komen wilde banken over het algemeen bij lagere zoutgehaltes voor, terwijl de kweekpercelen vooral in gebieden met relatief hoge zoutgehaltes liggen. Het onderzoek laat zien dat de biodiversiteit groter is bij hogere zoutgehaltes. Wanneer wilde banken en kweek-

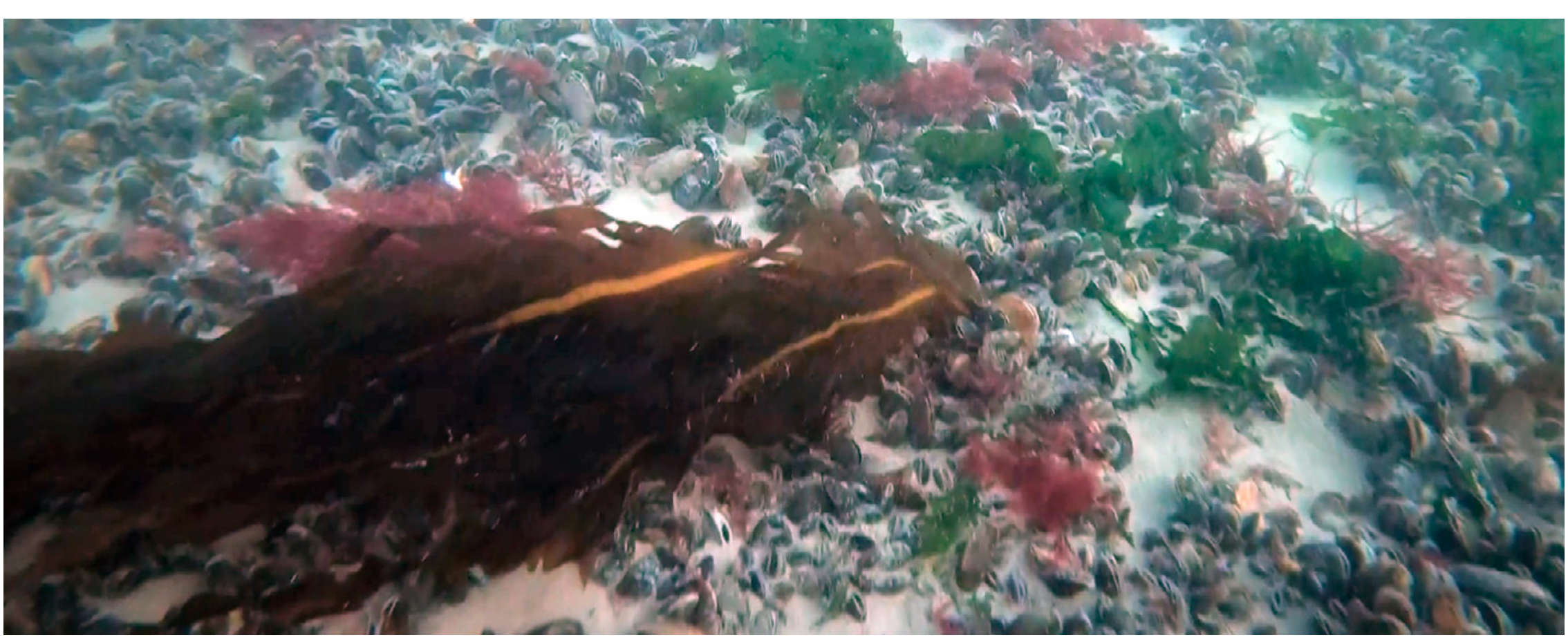

percelen worden vergeleken die wél vlak bij elkaar liggen, dan blijkt juist het aantal soorten in de wilde banken iets hoger te zijn. Ten tweede houden de mosselkwekers de percelen zo veel mogelijk schoon van zeesterren, die mosselen en geassocieerde soorten opeten ${ }^{32}$.

Op de kweekpercelen bestaat een duidelijk verband tussen de mosselen en de biodiversiteit; hoe meer mosselen, hoe meer andere soorten ${ }^{43,57}$. Op de kweekpercelen zijn welis-

waar meer verschillende soorten aanwezig, maar op de wilde banken komen deze geassocieerde soorten juist vaker voor. Het gaat dan vooral over soorten die voorkomen op zacht substraat zoals zanderige bodems (bijvoorbeeld de groene zeeduizendpoot, de strandgaper en het wadslakje). Soorten die juist meer voorkomen op de kweekpercelen zijn o.a. de Amerikaanse zwaardschede, de zeester en mosdiertjes ${ }^{32}$.
Mosselzaadvisserij

Beheer

\section{Biodiversiteit}

Rol mosselbanken

Ontwikkeling sublitorale banken

\section{Samenstelling} bodemdieren

Visserijeffecten bodemdieren

Gebiedssluiting sublitoraal

Draagkracht

\section{Sediment}

\section{(1)} (20.8) 18 


\section{Welke effecten heeft mosselzaadvisserij op de bodemdierengemeenschap?}

Mosselzaadvisserij

De mosselzaadvisserij kan gevolgen hebben voor de biodiversiteit van de Waddenzee, bijvoorbeeld door het wegvissen van een (deel) van de wilde zaadbanken. Tussen 2006 en 2012 zijn beviste delen van een sublitorale mosselbank vergeleken met onbeviste delen (referentiegebieden). Dit onderzoek laat zien dat er vlak na bevissing een negatief effect van de visserij op de sublitorale mosselbanken is. De zaadbanken zijn niet verdwenen, maar direct na de visserij is er wel een lagere dichtheid aan mosselen ${ }^{43,57}$ en aan geassocieerde soorten ${ }^{40,41,44}$. Dat resultaat is geheel volgens verwachting; er is immers gevist.

Na 1,5 jaar kunnen er geen verschillen meer worden aangetoond tussen de beviste delen binnen een mosselbank en de onbeviste controlegebieden. Het is aannemelijk dat dit komt omdat na de visserij nog steeds voldoende mosselen overblijven om structuur te bieden voor de hernieuwde ontwikkeling van de zaadbanken ${ }^{43,57}$. Het onderzoek laat ook zien dat de variatie in biomassa en voorkomen van geassocieerde soorten, zoals anemonen, in een mosselbank sterk varieert in tijd en onafhankelijk is van menselijke activiteiten. De natuurlijke dynamiek van de Waddenzee speelt hier een grote rol $^{40,44}$.
De mindere hoeveelheid strandkrabben en zeesterren direct na bevissing is te verklaren omdat met het opvissen van het mosselzaad, een belangrijke voedselbron voor deze soorten verdwenen is. Daarnaast worden de krabben en zeesterren opgevist. Het gaat voor deze soorten dus om zowel een indirect als een direct effect van de zaadvisserij. In het geval van anemonen kan de afgenomen dichtheid als een direct effect worden toegeschreven aan de zaadvisserij; zij worden opgevist ${ }^{41}$.

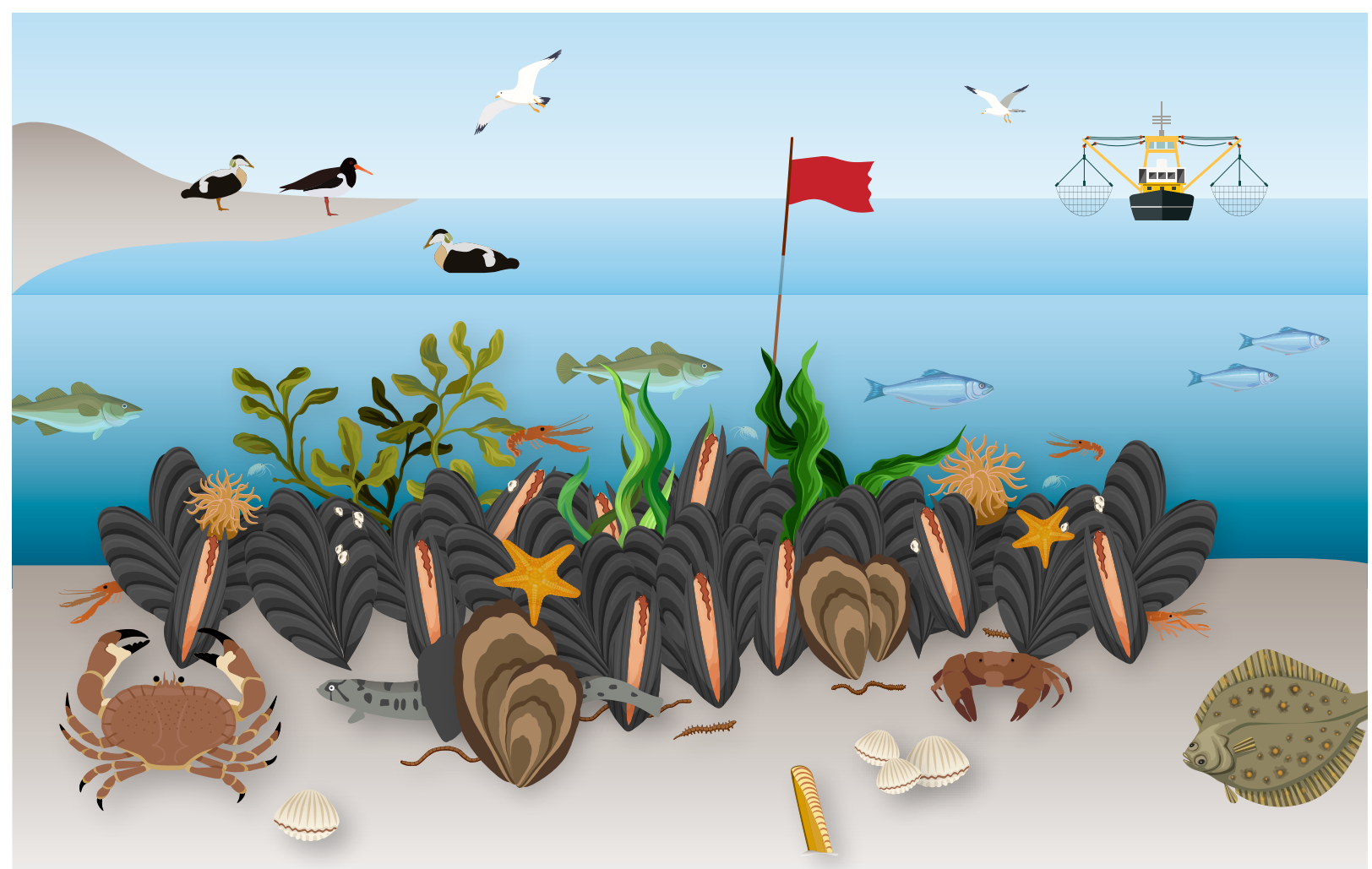

Beheer

\section{Biodiversiteit}

Rol mosselbanken

Ontwikkeling sublitorale banken

Samenstelling bodemdieren

Visserijeffecten bodemdieren

Gebiedssluiting sublitoraal

Draagkracht

\section{Sediment}

\section{(14)} 주잉 


\section{Wat zijn de effecten van de sluiting van sublitorale gebieden voor visserij op de bodemdierengemeenschap?}

In de westelijke Waddenzee is sinds 2014 een aantal gebieden gesloten voor de mosselzaad- en de garnalenvisserij. Het doel is om natuurontwikkeling te bevorderen. De ontwikkeling van het areaal sublitoraal mosselbanken en van het bodemleven in de open en de gesloten gebieden wordt

daarom jaarlijks gevolgd en vergeleken ${ }^{45}$. Over de eerste vijf jaar van het onderzoek (2015-2019) zijn geen verschillen in ontwikkeling gezien die zouden kunnen wijzen op een veranderde bodemdiergemeenschap door de gebiedssluiting voor mosselzaadvisserij ${ }^{45,48}$. Wel zijn er verschillen gevonden die veroorzaakt worden door de gebiedskeuze. Juist soortenrijke gebieden, waar in het verleden vaak meerjarige mosselbanken werden gevonden, zijn namelijk gesloten ${ }^{45}$. De gesloten en open gebieden waren dus al bij aanvang van het onderzoek verschillend.

De termijn waarop effecten van gebiedssluitingen voor (schelpdier)visserij op bodemdieren optreden, en welke effecten dit zijn, is onderzocht in een literatuurstudie ${ }^{48}$. Directe effecten van visserij, zoals het onttrekken van mosselen en daarmee geassocieerde soorten, zijn alleen op de korte termijn aangetoond ${ }^{40,41,43,44,57}$. De verschillende studies vonden geen bewijs voor lange termijn effecten op bodemdiergemeenschappen. Dat wil niet zeggen dat deze effecten er niet zijn, maar vaak is de onderzoeksopzet beperkt en worden er bijvoorbeeld geen referentiegebieden meegenomen. Ook kan het zijn dat de (grote) natuurlijke dynamiek een grotere rol speelt in het voorkomen van de bodemdiergemeenschap dan de effecten van de visserij. De opzet van het onderzoek naar de effecten van mosselzaadvisserij op de ontwikkeling van de bodemdierengemeenschap $40,41,44,57$ is goed. Visserijeffecten die langer dan 1,5 jaar aanhouden, kunnen echter niet aangetoond worden omdat de natuurlijke dynamiek veel bepalender blijkt.
Er zijn verschillende mogelijke verklaringen voor het uitblijven van een toename in het areaal aan meerjarige mosselbanken in de gesloten gebieden, vijf jaar na sluiting:

1 de visserij heeft geen wezenlijk effect op de ontwikkeling en overleving van meerjarige banken;

2 het effect van de visserij valt in het niet bij de natuurlijke dynamiek;

3 de huidige monitoring is onvoldoende om effecten statistisch aan te kunnen tonen;

4 de onderzoeksperiode is nog te kort om effecten aan te kunnen tonen.

Het onderzoek gaat om de laatste reden de komende jaren verder.
Mosselzaad-

visserij

\section{Beheer}

\section{Biodiversiteit}

Rol mosselbanken

Ontwikkeling sublitorale banken

Samenstelling bodemdieren

Visserijeffecten bodemdieren

\section{Gebiedssluiting}

sublitoraal

\section{Draagkracht}

\section{Sediment}

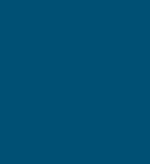




\section{Hoeveel mosselzaad ligt er in het sublitoraal van de Waddenzee?}

Mosselzaad-

visserij

Het bestand op de wilde mosselbanken in het sublitoraal is door natuurlijke omstandigheden aan fluctuaties onderhevig. In sommige jaren vindt vrijwel geen zaadval plaats, en in sommige jaren is er juist een massale zaadval. Vanaf de start van het jaarlijkse onderzoek in 1992 fluctueert het bestand aan zaad op de sublitorale wilde mosselbanken van de westelijke Waddenzee tussen de 0 en 93 miljoen kilo versgewicht (inclusief schelp), ten tijde van de voorjaarsvisserij. Dit betekent dat de kwekers in sommige jaren niet of maar heel weinig mosselzaad mogen oogsten. Door de introductie van mosselzaadinvanginstallaties (MZI's) zijn de kwekers minder afhankelijk van de wilde mosselzaadbestanden ${ }^{17}$.

\section{Beheer}

Biodiversiteit

\section{Draagkracht}

Bestand

Draagkracht ecosysteem

\section{Sediment}

1

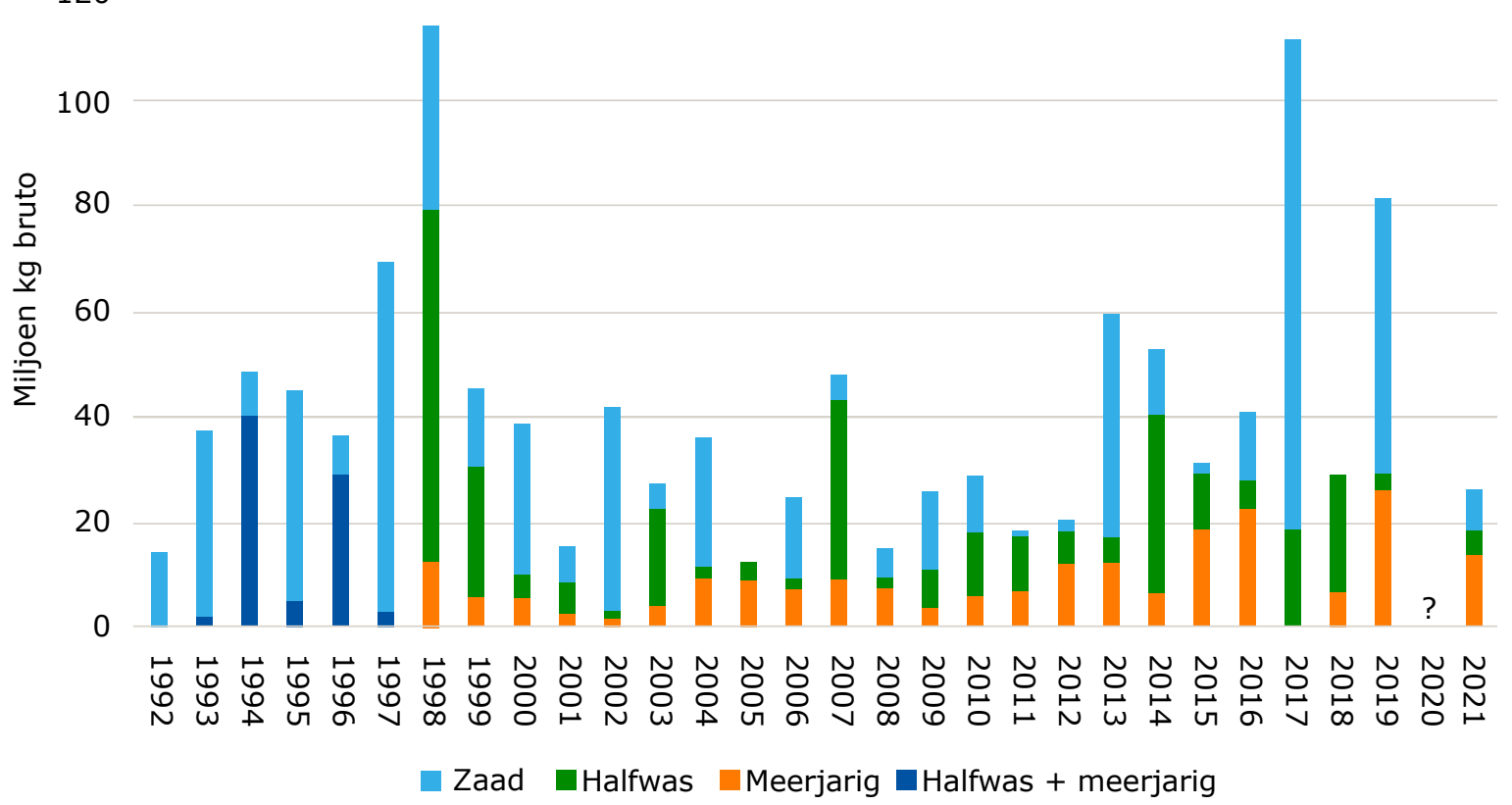

Ontwikkeling mosselbestand sublitoraal Waddenzee ${ }^{15}$

\section{(}

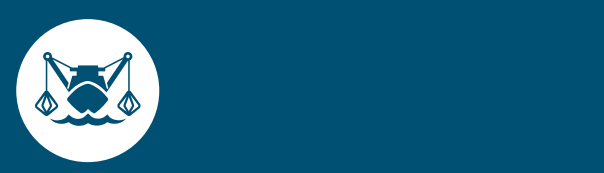




\section{Welke invloed heeft mosselkweek op de draagkracht voor schelpdieren?}

\section{Mosselzaad-}

visserij

Schelpdieren voeden zich door microalgen uit het water te filteren. Wanneer er zo veel micro-algen worden gegeten dat de groei (aanwas) van de algen wordt afgeremd (overbegrazing), is het schelpdierbestand te groot. De zogenaamde draagkracht van het ecosysteem voor schelpdieren wordt dan overschreden. De schelpdieren kunnen dan niet meer optimaal groeien. Dit kan negatief doorwerken naar soorten die afhankelijk zijn van schelpdieren, zoals vogels. Gekweekte schelpdierbestanden concurreren om voedsel met

natuurlijk voorkomende schelpdieren. Een optimaal evenwicht tussen natuur en productie is daarom belangrijk.

Mosselkweek draagt substantieel bij aan de omvang van het totale schelpdierenbestand en kan daarom effect hebben op de draagkracht. In de Oosterschelde vormen de kweek-

mosselen ongeveer $30 \%$ van het totale schelpdierenbestand; in de westelijke Waddenzee is dit ongeveer $20 \%{ }^{71}$. Recent

onderzoek laat zien dat de draagkracht van de Oosterschelde en Waddenzee voor schelpdieren momenteel niet onder druk staat $^{71}$.

Voor de Oosterschelde concluderen eerdere studies dat er voor de periode 1995-2009 aanwijzingen voor overbegrazing zijn $^{72}$. Sindsdien hebben veranderingen plaatsgevonden, zoals een afname van het oesterbestand door de oesterboorder en het herpesvirus. De meest recente inzichten zijn dat het totale schelpdierbestand in de Oosterschelde en daarmee de totale graasdruk (het wegfilteren van voedsel door schelpdieren) van jaar tot jaar varieert. Er zijn geen duidelijke toe- of afnemende trends. Het oesterbestand is weliswaar afgenomen, maar hierdoor is er geen substantiële daling van de graasdruk van het gehele schelpdierbestand. Er zijn geen aanwijzingen dat de huidige bestanden aan schelpdieren, inclusief de gekweekte mosselen, op dit moment directe invloed uitoefenen op de productiviteit van het

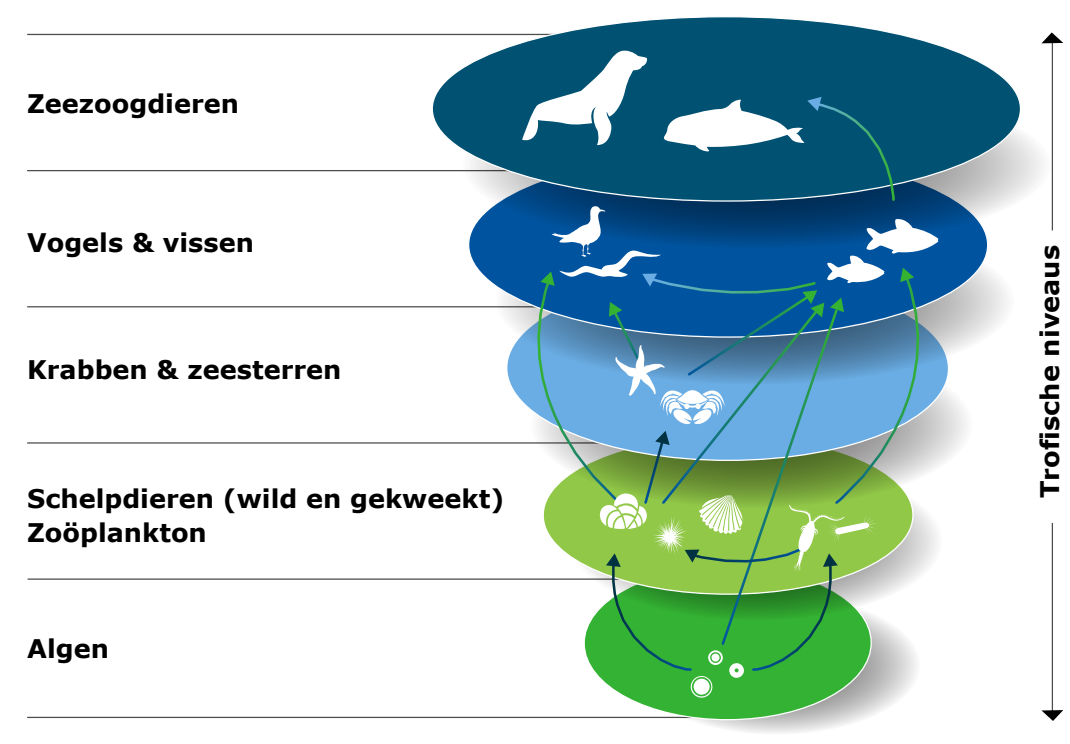

ecosysteem en het actuele voedselaanbod in de Oosterschelde. Meer schelpdieren lijken vooralsnog niet direct tot een lagere micro-algen populatie te leiden ${ }^{71}$. De groei van micro-algen populaties worden naast de begrazing door schelpdieren ('top down') bepaald door de nutriënten toevoer ('bottom up'). Hoe veranderingen in nutriëntenconcentraties de afgelopen jaren de productiviteit beïnvloed hebben, is geen onderdeel van de recente studie.

In de Waddenzee leveren niet de kweekmosselen maar andere wilde schelpdiersoorten, zoals de strandgaper, de grootste bijdrage aan de graasdruk. In de gebieden in de westelijke Waddenzee, waar de kweekpercelen liggen, is het niet waarschijnlijk dat overbegrazing optreedt; ook niet in het Marsdiep waar de (wilde) schelpdierenbestanden en de bijbehorende graasdruk sterk zijn toegenomen ${ }^{71}$. De bevinding dat de draagkracht in de westelijke Waddenzee niet overschreden wordt, komt overeen met een recente studie op Balgzand ${ }^{73}$.
Beheer

Biodiversiteit

\section{Draagkracht}

Bestand

Draagkracht ecosysteem

\section{Sediment}
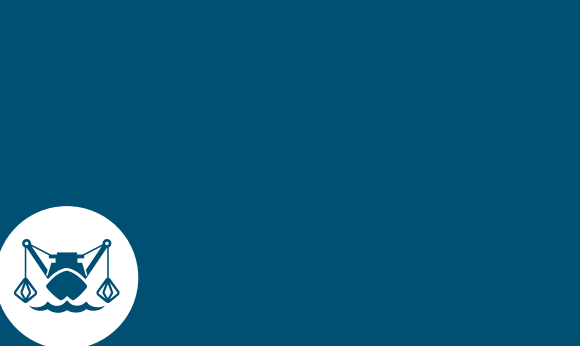


\section{Leidt mosselzaadvisserij en -kweek tot vertroebeling van het water door opwerveling van sediment?}

De Waddenzee kent van nature grote sedimenttransporten. Verhoogde vertroebeling en sedimentatie kunnen gevolgen hebben voor het ecosysteem. Naast natuurlijke oorzaken kunnen ook menselijke activiteiten, zoals baggeren, kustverdediging en bodemvisserij, van invloed zijn op de sedimenthuishouding ${ }^{69,70}$. In 2017 is de sedimentdynamiek rond beviste mosselzaadbanken en in de directe omgeving van mosselpercelen onderzocht. De onderzoekslocaties zijn zo gekozen dat de hoogst mogelijke effecten gemeten konden worden (bijvoorbeeld hele slikkige gebieden of gebieden met hoge visserij-intensiteit) ${ }^{69}$.

In de gebieden waar wordt gevist of geoogst, wordt het water tijdelijk troebeler. De grootte van de sedimentpluim (zichtbaar opgewoeld sediment) blijft beperkt tot de directe omgeving van de mosselzaadvisserij of het oogsten van de percelen (binnen enkele tientallen tot honderd meters). De troebelheidsmetingen laten zien dat de sedimentpluim vrijwel direct na het vissen verdwijnt ${ }^{69}$. Dit duidt er op dat veel van het opgewoelde sediment direct weer op of in de nabijheid van het perceel of op de zaadbank neervalt.

De gemeten troebelheid door visserij op zaadbanken en percelen verschilt per gebied en per activiteit. Dit komt door (combinaties van) verschillende factoren, zoals visserijintensiteit, type activiteit (zaadvisserij versus oogsten, of schoonvissen, waarbij voor de nieuwe kweekcyclus zoveel mogelijk slib wordt verwijderd van het perceel), sedimenttype, diepte, stromingspatronen, wind, golven, en seizoen. De hoogste troebelheidswaarde is gevonden tijdens de mosselzaadvisserij. Tussen meerdere vissende schepen is tot maximaal 40x hogere concentraties gemeten ten opzichte van achtergrondwaardes. Bij de oogst op de kweekpercelen is maximaal een $8 x$ hogere concentratie gemeten ten opzichte van de achtergrondwaardes. Deze maximale waarden zijn

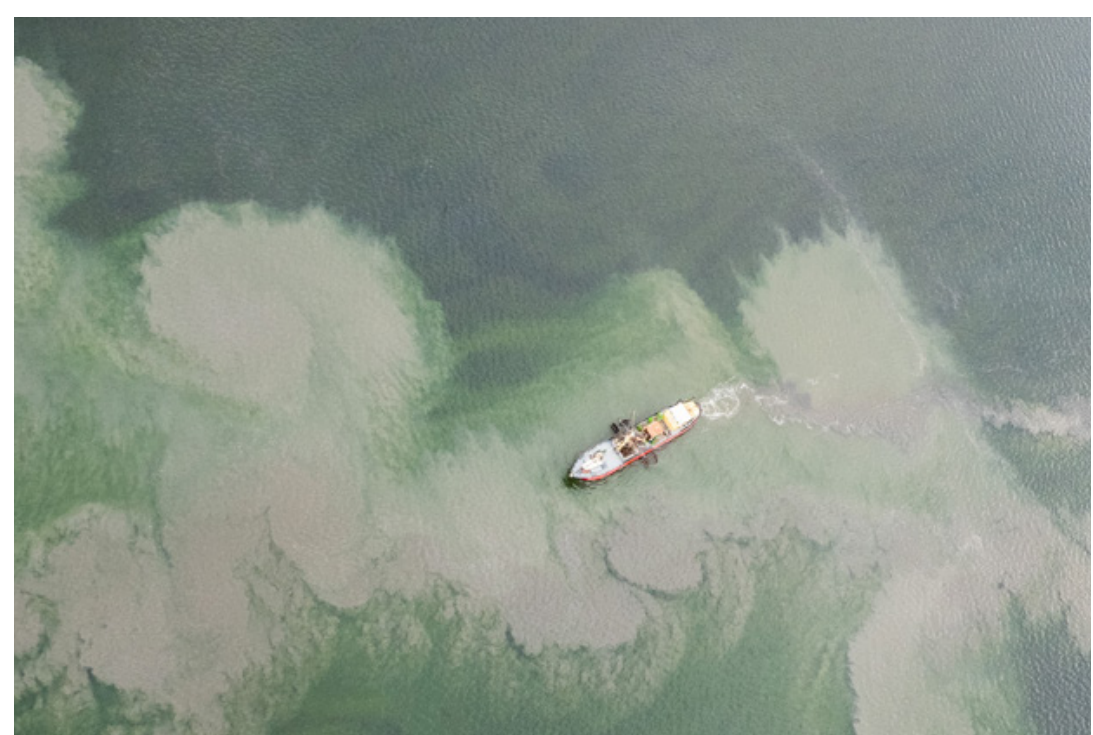

Beheer

Biodiversiteit

Draagkracht

\section{Sediment}

Vertroebeling

voor zowel de zaadvisserij en de oogst op de percelen hoger dan de hoogste meetwaarden in de langjarige monitoring programma's van de gehalten zwevend materiaal in de geulen. Deze langjarige monitoring vindt om technische reden echter niet plaats tijdens stormen. Dit is juist de periode wanneer de natuurlijke slibwaarden (en dus de gehalten zwevend materiaal) het hoogst zijn ${ }^{69}$.

De rol van mosselen in de sedimentdynamiek kent twee kanten. Mosselen filteren continue zwevend materiaal uit de waterkolom en leggen dit vast in mosselweefsel door groei, of als (pseudo)feces op de bodem. De filtratie zorgt voor een helderdere waterkolom, met een positief effect op de waterkwaliteit. Het onderzoek laat zien dat de visserij bodemmateriaal op wervelt. Hierdoor kan de troebelheid kortstondig en lokaal sterk toenemen op het moment dat de mosselen worden opgevist. Deze effecten van visserijactiviteiten zijn kortdurend (alleen tijdens de activiteit zelf), terwijl de effecten van filtratie continu plaatsvinden ${ }^{69}$.

\section{(4)} 300 


\section{Wat zijn $M Z I^{\prime} s ?$}

Mosselzaadinvanginstallaties (MZI's) bestaan uit drijvers (boeien, buizen) met daaraan substraat in de vorm van touwen of netten. Mossellarven kunnen zich in het voorjaar en de vroege zomer aan dit substraat hechten. Het mosselzaad wordt in de zomer en het najaar van de MZI's geoogst en direct daarna op de kweekpercelen uitgezaaid ${ }^{18}$.

De eerste experimenten met MZI's stammen uit begin 2000 Twintig jaar later is deze manier van mosselzaad oogsten een onlosmakelijk onderdeel van de bedrijfsvoering van de meeste mosselbedrijven ${ }^{17}$. De $M Z I^{\prime}$ 's bieden meer zekerheid

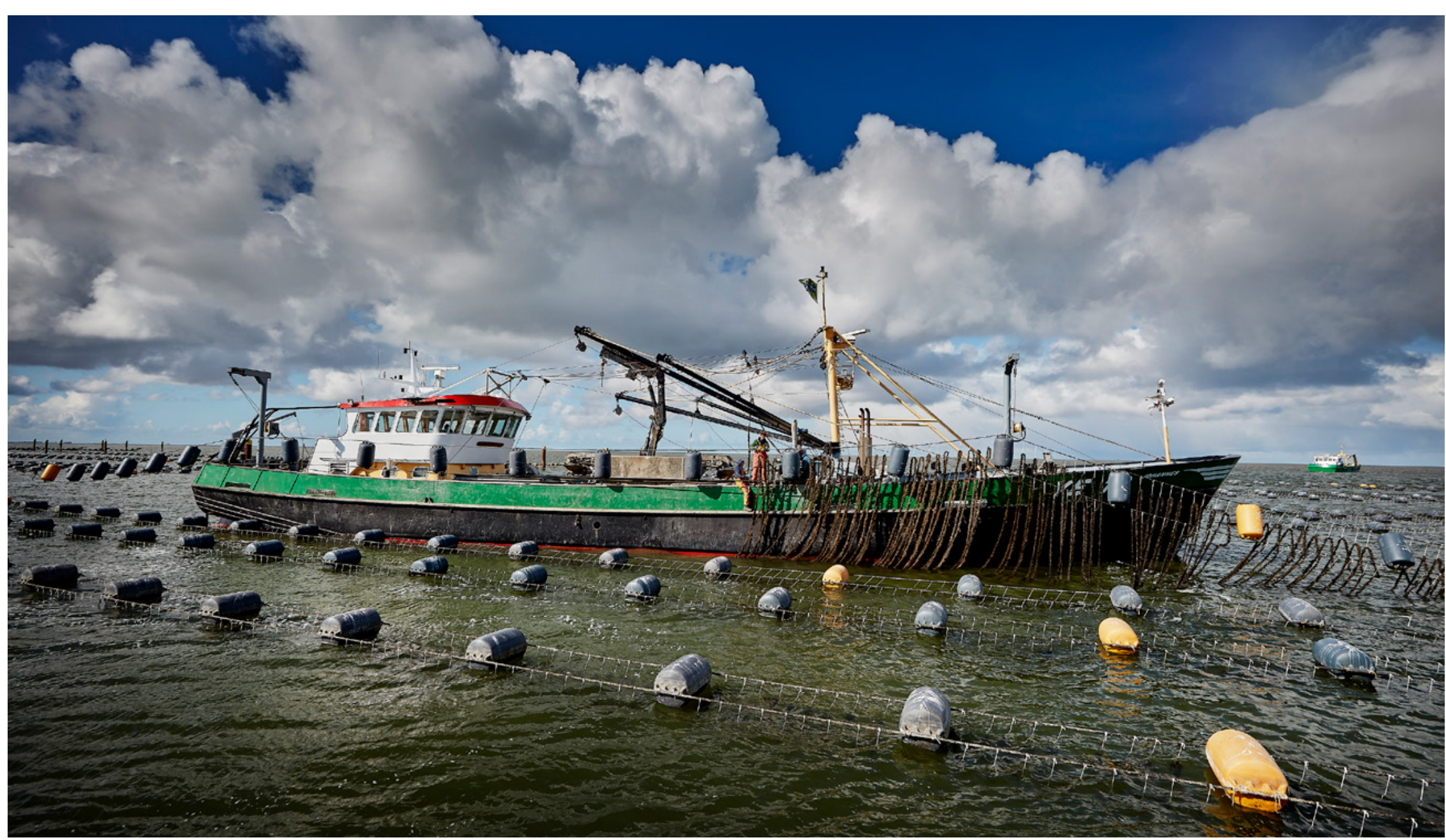

over de beschikking van zaad voor de kweek. Dit komt omdat de overleving van mosseltjes in de waterkolom beter is dan de overleving op de bodem ${ }^{18}$. Over een periode van vijf jaar wijkt de hoeveelheid bodemzaad in een gegeven jaar een factor 2,8 af van het gemiddelde. Voor het MZI-zaad is deze afwijking maar $0,1^{17}$. Dit betekent dat $M Z I^{\prime} s$ een betrouwbare bron van mosselzaad zijn. Verlies van MZI-zaad ontstaat door het in de war raken van de touwen, schade aan de MZI-systemen zelf, vraat door zeesterren of aangroei (weerbomen, mosdiertjes, zakpijpen) op de systemen ${ }^{18}$.

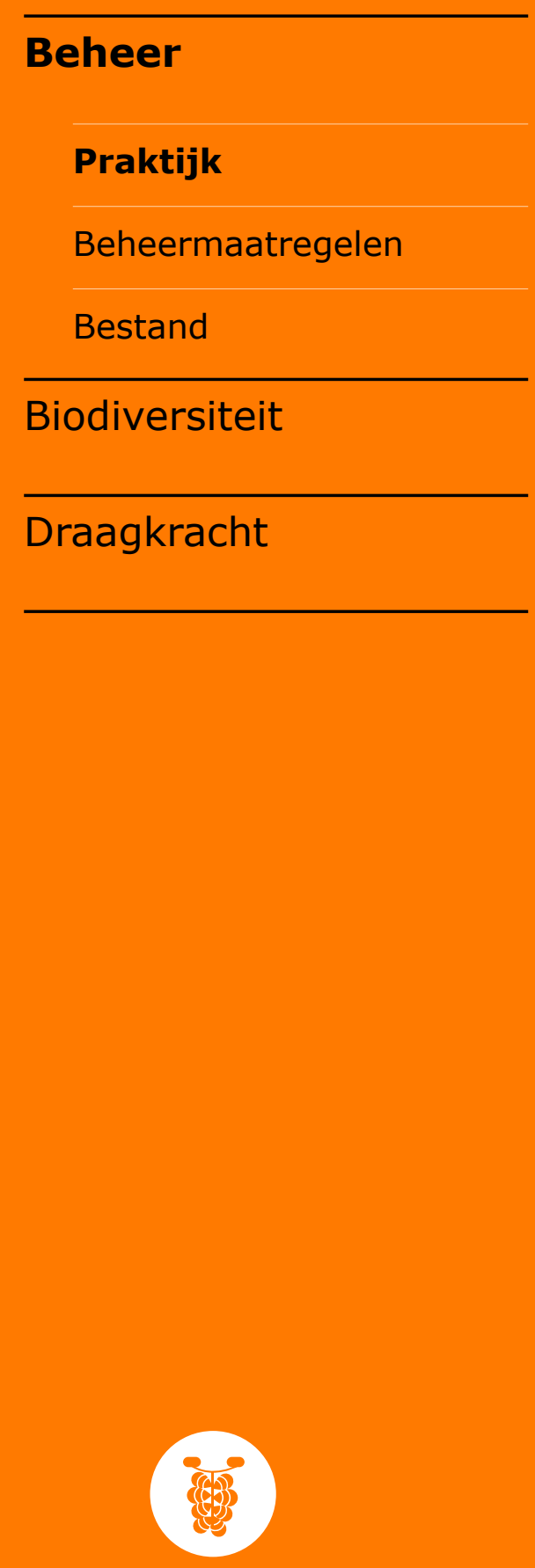




\section{Hoe worden de MZI's beheerd?}

In de Waddenzee en Zeeuwse Delta zijn gebieden aangewezen waar mosselzaadinvanginstallaties (MZI's) mogen worden geplaatst. Verschillende bedrijven maken gebruik van dezelfde locatie. Deze MZI-clusters zijn zo ingedeeld dat het ruimtegebruik binnen de locaties zo efficiënt mogelijk is.

Binnen de clusters werken bedrijven vaak samen om kosten te besparen. Niet alle mosselkweekbedrijven hebben MZI's.

De bedrijven die geen eigen MZI's hebben, behoren tot een minderheid en gebruiken vaak wel MZI-zaad ${ }^{17}$.

In 2019 werd ongeveer $70 \%$ van de beschikbare $M Z I$-locaties in de Waddenzee gebruikt; in de Zeeuwse Delta 40\%. De bedrijven met MZI's moeten ieder jaar de gegevens over het gebruik en de oogst aan het ministerie van Landbouw, Natuur en Voedselkwaliteit doorgeven ${ }^{18}$.

Voor het plaatsen, verwijderen en gebruik van de MZI's is een $W n b$-vergunning nodig. Hieronder valt sinds 2020 ook een beoordeling van de mogelijke effecten van stikstofuitstoot. De $M Z I$-locaties zelf zijn getoetst aan de Waterwet (veiligheid voor de scheepvaart).

Volgens de mosselkwekers kunnen de mosselpercelen in de directe nabijheid van MZI's last hebben van meer zeesterren, mindere groei door voedsel- concurrentie of MZI-zaadval op de percelen. Over deze zogenaamde schaduwwerking ${ }^{19}$ is weinig bekend. Een beperkte studie kon dit effect niet aantonen ${ }^{20}$. In het beleid is mede daarom vastgelegd dat kweekpercelen niet voor MZI's mogen worden gebruikt. Ook geldt tussen MZI's en kweekpercelen een afstand van minimaal $200 \mathrm{~m}^{21}$

\section{Beheer}

Praktijk

\section{Beheermaatregelen}

Bestand

Biodiversiteit

\section{Draagkracht}

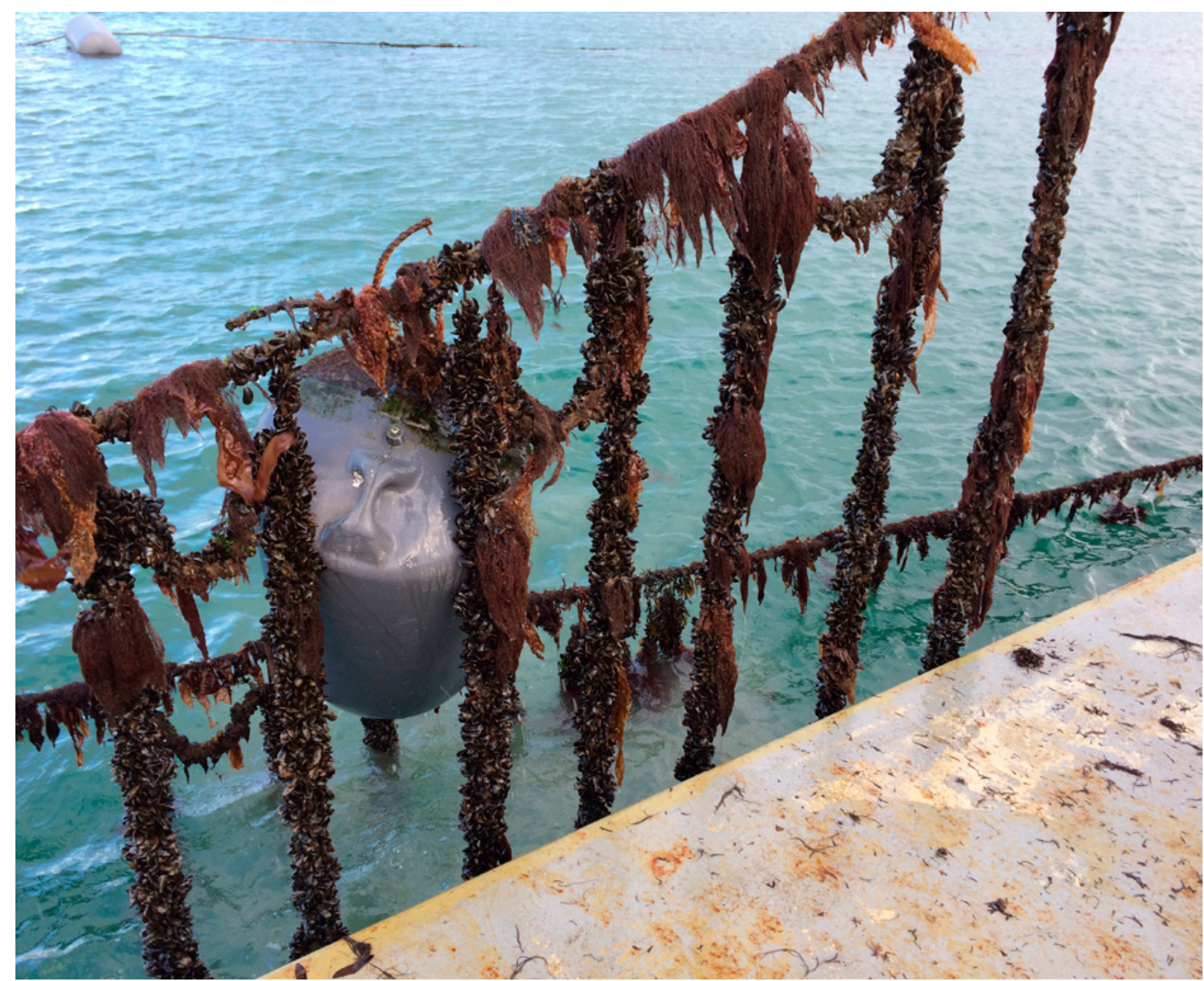




\section{Hoeveel mosselzaad komt uit de MZI's?}

De productie per MZI-locatie wordt door vier factoren bepaald

1 de beschikbare ruimte (vergunde oppervlak) en

daarmee de fysieke mogelijkheid om MZI's uit te zetten,

2 de mate waarin het gebied gebruikt is/bruikbaar is voor het uitzetten van MZI's,

3 de hydrodynamische en biologische eigenschappen van de locatie, en

4 de technische eigenschappen van het MZI-systeem ${ }^{18}$.

Over de periode 2009-2019 neemt de MZI-oogst in de Waddenzee en de Zeeuwse Delta toe van 8 tot 19 miljoen $\mathrm{kg}$. Het invangresultaat (oogst per eenheid substraat) is vrij stabiel. In dezelfde periode vist de mosselzaadvisserij in de nog resterende open gebieden jaarlijks gemiddeld 21 miljoen $\mathrm{kg}$ mosselzaad, met een sterk variërend mosselzaadbestand tussen de jaren (0-41 miljoen kg per jaar) (gegevens WMR).

Het aandeel MZI-zaad uit de Waddenzee neemt sinds 2009 toe ten opzichte van de Oosterschelde. In 2009 komt 51\% van het MZI-zaad uit de Waddenzee en $45 \%$ uit de Ooster- schelde; in 2019 is dit respectievelijk 85\% ten opzichte van $11 \%$. Het aandeel MZI-zaad uit de Voordelta is met $2-4 \%$ van het totaal relatief constant. De verschillen hebben waarschijnlijk te maken met het invangresultaat (oogst per meter touw of per vierkante meter net). Dit is beter in de Waddenzee $\left(3,2 \mathrm{~kg} / \mathrm{m}\right.$ touw en $41,1 \mathrm{~kg} / \mathrm{m}^{2}$ net) en Voordelta $\left(2,3 \mathrm{~kg} / \mathrm{m}\right.$ touw en $42,6 \mathrm{~kg} / \mathrm{m}^{2}$ net $)$ dan in de Oosterschelde $\left(2,7 \mathrm{~kg} / \mathrm{m} \text { touw en } 24,0 \mathrm{~kg} / \mathrm{m}^{2} \text { net }\right)^{18}$.

Het MZI-zaad uit de Waddenzee blijft voor het grootste deel in het gebied. Slechts een klein deel wordt uitgezaaid op de percelen in de Oosterschelde (6\% in 2019). Een deel van het MZI-zaad uit de Oosterschelde wordt uitgezaaid op de percelen in de Waddenzee (ca. $10 \%$ in 2019) ${ }^{18}$.

Onderzoek laat zien dat er geen grote verschillen in kweekrendement tussen MZI-zaad en bodemzaad zijn. Het kweekrendement is de hoeveelheid consumptiemosselen die uit een kilo zaad komt. Als er al een verschil is, dan komt dit vooral door de grootte van het zaad 22 .

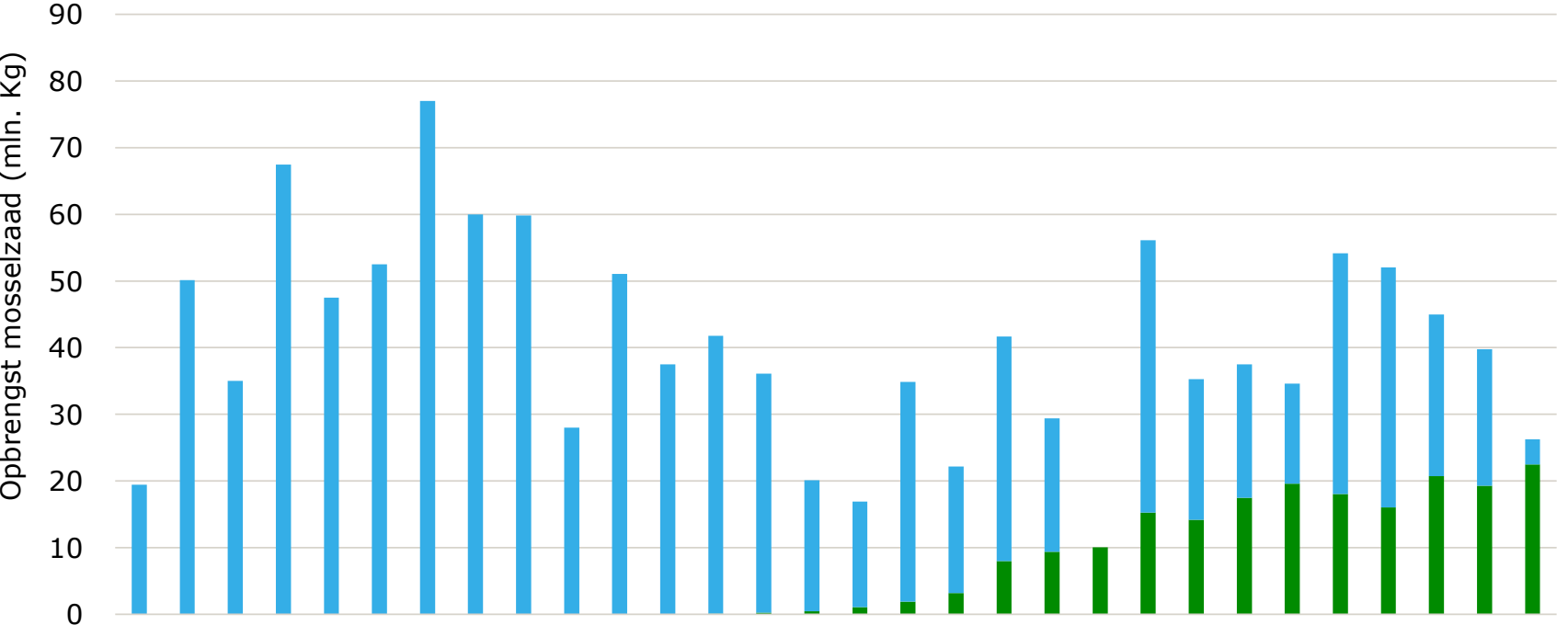

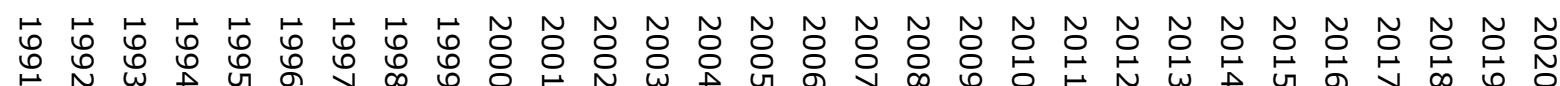

Opbrengst mosselzaad 1991-2021 Bron: Actualisatie figuur 3.2 uit 18; PO Mosselcultuur.

\section{Beheer}

Praktijk

Beheermaatregelen

Bestand

\section{Biodiversiteit}

\section{Draagkracht}

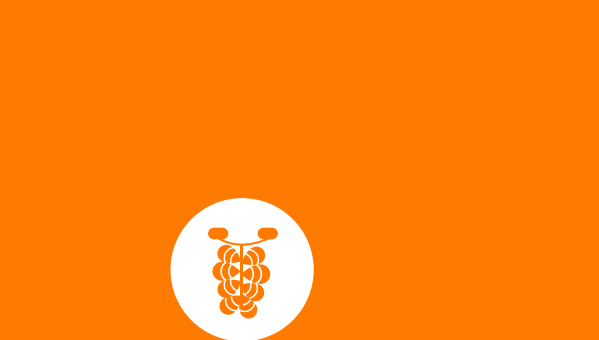




\section{Hoe zit het met $M Z I^{\prime}$ s en biodiversiteit?}

Kwekers die MZI's gebruiken melden dat er op de MZIsystemen aangroei kan zijn van weerbomen, mosdiertjes en zakpijpen, en vestiging van zeesterren ${ }^{18}$. De biodiversiteit op MZI locaties wordt daarmee tijdelijk vergroot, wat vervolgens ook (jonge) vis kan aantrekken ${ }^{64}$. In 2008 en 2009 is onderzocht welke planten en dieren in verschillende mosselkweeksystemen in de Oosterschelde en de Waddenzee leven: bodemkweek, hangcultures en MZI's. Op de MZI's werden in 200949 verschillende soorten gevonden (64 in 2008) (55 $^{6}$. Het is daarmee aannemelijk dat $M Z I^{\prime} s$, in ieder geval in de periode dat zij in het water liggen, tot een lokale vergroting van de biodiversiteit leiden. Dit wordt ondersteund door studies naar hangcultures van schelpdieren. In de waterkolom rond deze hangcultures is er een grotere diversiteit aan soorten, die vergelijkbaar is met natuurlijke riffen ${ }^{64}$. Aangetekend moet worden dat hangcultures een langere periode in het water liggen dan MZI's. Na het onderzoek in 2008 en 2009 is er geen systematisch onderzoek gedaan naar de relatie tussen MZI's en biodiversiteit.

MZI's

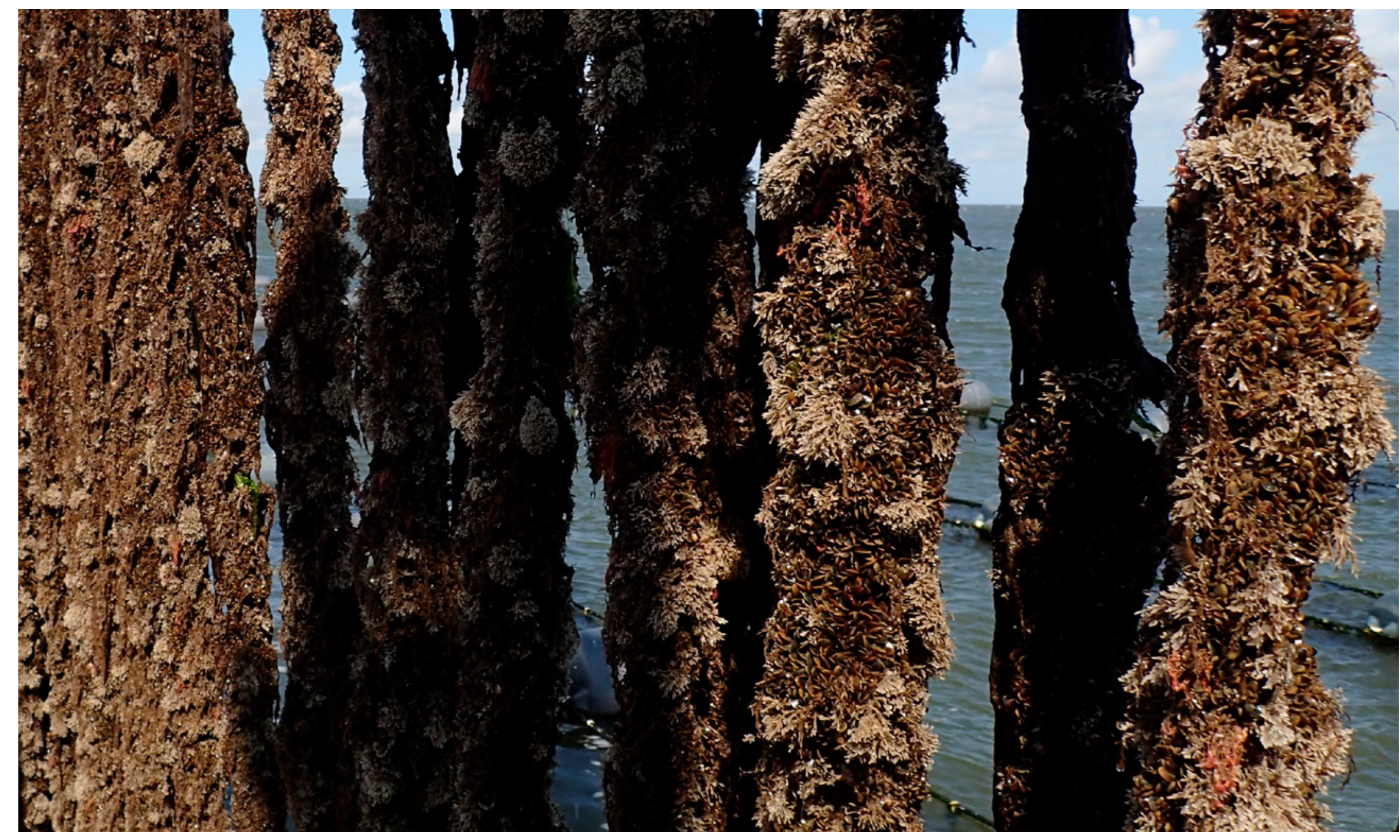

Beheer

Biodiversiteit

Soortensamenstelling

Bodemkwaliteit

Draagkracht

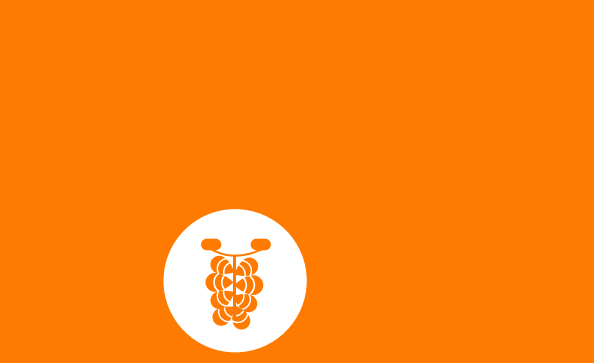




\section{Wat zijn de effecten van $M Z I^{\prime}$ s op de bodemkwaliteit?}

Direct onder MZI's zou sprake kunnen zijn van ophoping van organisch materiaal door uitzinking van (pseudo)feces. Deze zogenaamde verrijking is bekend voor hangcultures en kan lokaal gevolgen hebben voor de bodemstructuur, bodemleven en zuurstofgehalte in het water. In 2009 is een korte studie uitgevoerd naar de bodemkwaliteit onder de $M Z I^{\prime} s^{66}$. Er zijn 9 gebieden ( 5 in Waddenzee en 4 in Oosterschelde,) bemonsterd. Op iedere locatie zijn stroomopwaarts en stroomafwaarts op vaste afstanden tot de $M Z I$ bodemmonsters verzameld. Ook direct onder de MZI's zijn monsters verzameld. Er zijn geen aanwijzingen dat op het schaalniveau van de studie verrijking van de bodem plaats- vindt. Het is echter niet uit te sluiten dat er lokaal, in gebieden binnen $50 \mathrm{~m}$ afstand van de $M Z I$, tijdelijk wel sprake is van verrijking. Dit kon met de gebruikte methode niet worden achterhaald ${ }^{66,67}$.

Uit internationaal onderzoek naar hangcultures blijkt dat effecten van verrijking van de bodem en verminderd zuurstofgehalte vooral optreden in ondiepe, beschutte gebieden met weinig getijdenverschil68. Omdat MZI's in relatief diepe gedeeltes liggen in gebieden waar de waterverversing door het getij hoog is, is het onwaarschijnlijk dat zij bijdragen aan een verminderde bodemkwaliteit.

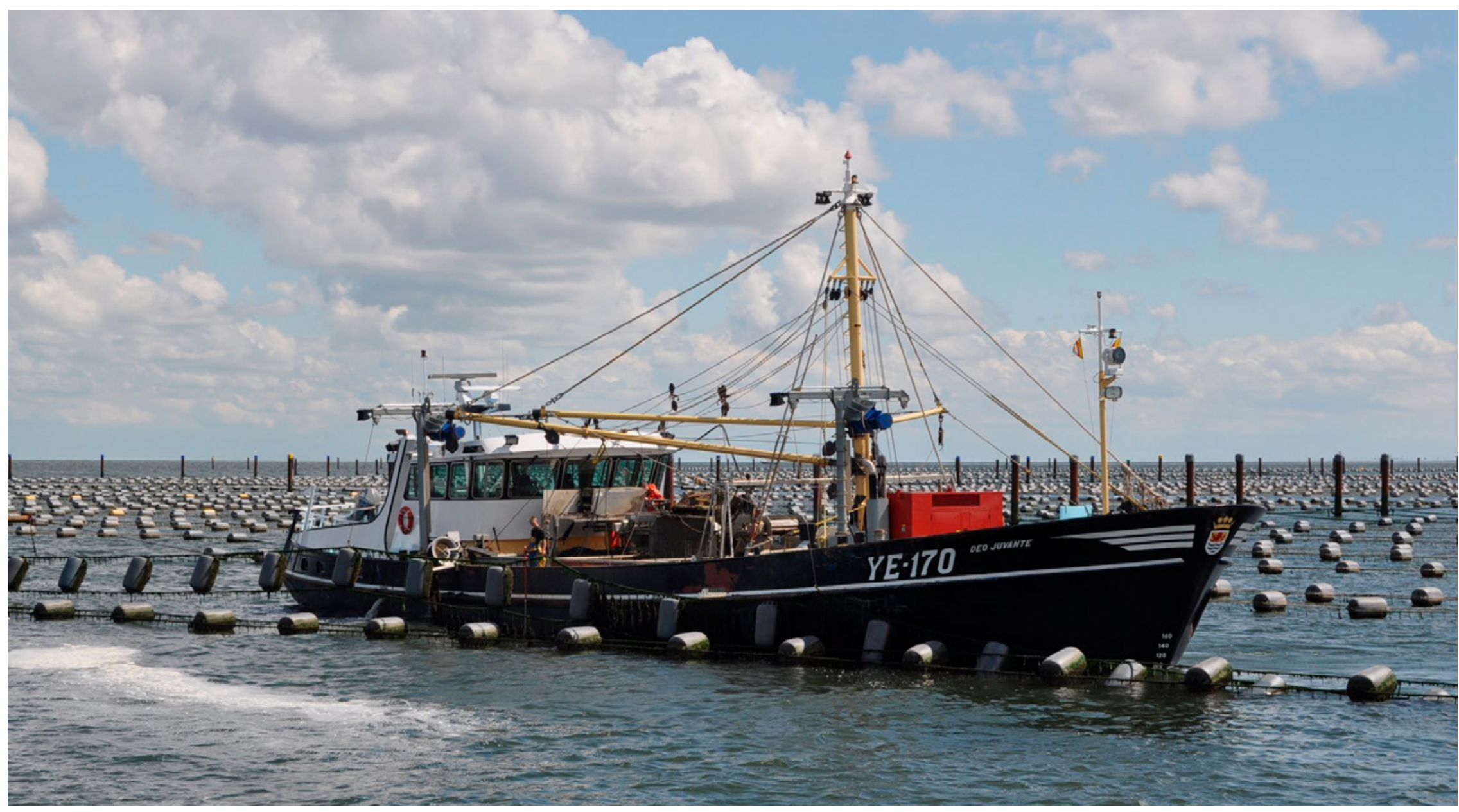

MZI's

Beheer

\section{Biodiversiteit}

Soortensamenstelling

Bodemkwaliteit

Draagkracht

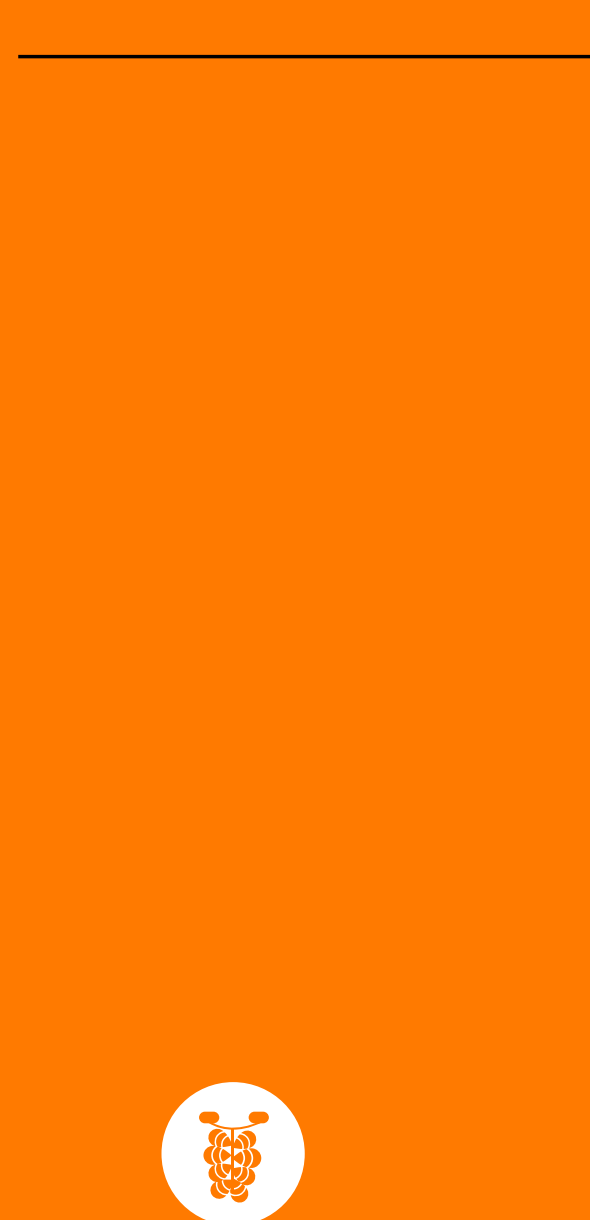




\section{Hoeveel mosselzaad komt uit de MZI's?}

De productie per MZI-locatie wordt door vier factoren bepaald

1 de beschikbare ruimte (vergunde oppervlak) en

daarmee de fysieke mogelijkheid om MZI's uit te zetten,

2 de mate waarin het gebied gebruikt is/bruikbaar is voor het uitzetten van MZI's,

3 de hydrodynamische en biologische eigenschappen van de locatie, en

4 de technische eigenschappen van het MZI-systeem ${ }^{18}$.

Over de periode 2009-2019 neemt de MZI-oogst in de Waddenzee en de Zeeuwse Delta toe van 8 tot 19 miljoen $\mathrm{kg}$. Het invangresultaat (oogst per eenheid substraat) is vrij stabiel. In dezelfde periode vist de mosselzaadvisserij in de nog resterende open gebieden jaarlijks gemiddeld 21 miljoen $\mathrm{kg}$ mosselzaad, met een sterk variërend mosselzaadbestand tussen de jaren (0-41 miljoen kg per jaar) (gegevens WMR).

Het aandeel MZI-zaad uit de Waddenzee neemt sinds 2009 toe ten opzichte van de Oosterschelde. In 2009 komt 51\% van het MZI-zaad uit de Waddenzee en $45 \%$ uit de Ooster- schelde; in 2019 is dit respectievelijk 85\% ten opzichte van $11 \%$. Het aandeel MZI-zaad uit de Voordelta is met $2-4 \%$ van het totaal relatief constant. De verschillen hebben waarschijnlijk te maken met het invangresultaat (oogst per meter touw of per vierkante meter net). Dit is beter in de Waddenzee $\left(3,2 \mathrm{~kg} / \mathrm{m}\right.$ touw en $41,1 \mathrm{~kg} / \mathrm{m}^{2}$ net) en Voordelta $\left(2,3 \mathrm{~kg} / \mathrm{m}\right.$ touw en $42,6 \mathrm{~kg} / \mathrm{m}^{2}$ net $)$ dan in de Oosterschelde $\left(2,7 \mathrm{~kg} / \mathrm{m} \text { touw en } 24,0 \mathrm{~kg} / \mathrm{m}^{2} \text { net }\right)^{18}$.

Het MZI-zaad uit de Waddenzee blijft voor het grootste deel in het gebied. Slechts een klein deel wordt uitgezaaid op de percelen in de Oosterschelde (6\% in 2019). Een deel van het MZI-zaad uit de Oosterschelde wordt uitgezaaid op de percelen in de Waddenzee (ca. $10 \%$ in 2019) ${ }^{18}$.

Onderzoek laat zien dat er geen grote verschillen in kweekrendement tussen MZI-zaad en bodemzaad zijn. Het kweekrendement is de hoeveelheid consumptiemosselen die uit een kilo zaad komt. Als er al een verschil is, dan komt dit vooral door de grootte van het zaad 22 .
Beheer

Biodiversiteit

\section{Draagkracht}

\section{Bestand}

Draagkracht

ecosysteem

Draagkracht lokaa
90

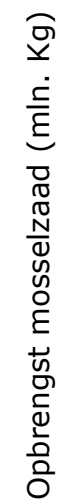

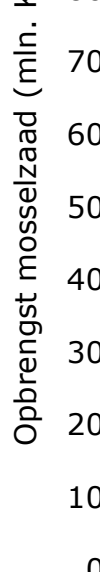




\section{Welke invloed heeft mosselkweek op de draagkracht voor schelpdieren?}

Schelpdieren voeden zich door microalgen uit het water te filteren. Wanneer er zo veel micro-algen worden gegeten dat de groei (aanwas) van de algen wordt afgeremd (over-

begrazing), is het schelpdierbestand te groot. De zogenaamde draagkracht van het ecosysteem voor schelpdieren wordt dan overschreden. De schelpdieren kunnen dan niet meer optimaal groeien. Dit kan negatief doorwerken naar soorten die afhankelijk zijn van schelpdieren, zoals vogels. Gekweekte schelpdierbestanden concurreren om voedsel met natuurlijk voorkomende schelpdieren. Een optimaal evenwicht tussen natuur en productie is daarom belangrijk.

Mosselkweek draagt substantieel bij aan de omvang van het totale schelpdierenbestand en kan daarom effect hebben op de draagkracht. In de Oosterschelde vormen de kweek-

mosselen ongeveer $30 \%$ van het totale schelpdierenbestand; in de westelijke Waddenzee is dit ongeveer $20 \%{ }^{71}$. Recent onderzoek laat zien dat de draagkracht van de Oosterschelde en Waddenzee voor schelpdieren momenteel niet onder druk staat $^{71}$.

Voor de Oosterschelde concluderen eerdere studies dat er voor de periode 1995-2009 aanwijzingen voor overbegrazing $z^{2 i j n}{ }^{72}$. Sindsdien hebben veranderingen plaatsgevonden, zoals een afname van het oesterbestand door de oesterboorder en het herpesvirus. De meest recente inzichten zijn dat het totale schelpdierbestand in de Oosterschelde en daarmee de totale graasdruk (het wegfilteren van voedsel door schelpdieren) van jaar tot jaar varieert. Er zijn geen duidelijke toe- of afnemende trends. Het oesterbestand is weliswaar afgenomen, maar hierdoor is er geen substantiële daling van de graasdruk van het gehele schelpdierbestand. Er zijn geen aanwijzingen dat de huidige bestanden aan schelpdieren, inclusief de gekweekte mosselen, op dit moment directe invloed uitoefenen op de productiviteit van het

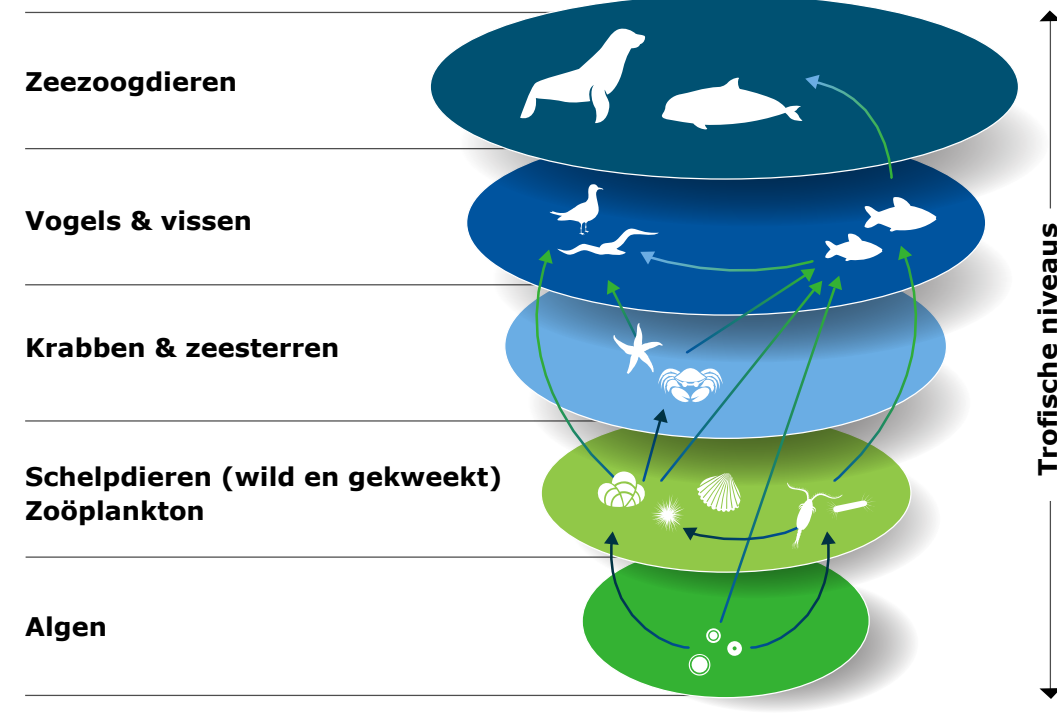

ecosysteem en het actuele voedselaanbod in de Oosterschelde. Meer schelpdieren lijken vooralsnog niet direct tot een lagere micro-algen populatie te leiden ${ }^{71}$. De groei van micro-algen populaties worden naast de begrazing door schelpdieren ('top down') bepaald door de nutriënten toevoer ('bottom up'). Hoe veranderingen in nutriëntenconcentraties de afgelopen jaren de productiviteit beïnvloed hebben, is geen onderdeel van de recente studie.

In de Waddenzee leveren niet de kweekmosselen maar andere wilde schelpdiersoorten, zoals de strandgaper, de grootste bijdrage aan de graasdruk. In de gebieden in de westelijke Waddenzee, waar de kweekpercelen liggen, is het niet waarschijnlijk dat overbegrazing optreedt; ook niet in het Marsdiep waar de (wilde) schelpdierenbestanden en de bijbehorende graasdruk sterk zijn toegenomen ${ }^{71}$. De bevinding dat de draagkracht in de westelijke Waddenzee niet overschreden wordt, komt overeen met een recente studie op Balgzand ${ }^{73}$
Beheer

Biodiversiteit

\section{Draagkracht}

Bestand

Draagkracht ecosysteem

Draagkracht lokaal

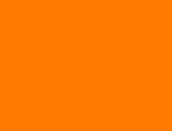

000 


\section{Is er een relatie tussen schelpdierbiomassa en lokale draagkracht?}

Als er (te) veel schelpdieren op een bepaalde plek of gebied liggen, kunnen lokaal voedseltekorten ontstaan. Dit kan gevolgen hebben voor de productie van wilde of gekweekte mosselen. Het is bekend dat de waterlaag direct boven mosselkweekpercelen een lagere voedselconcentratie kan hebben ${ }^{74,75}$. Dit is vooral het geval in gebieden met relatief lage stroming.

Mosselen in mosselzaadinvanginstallaties (MZI's) kunnen hun voedsel uit een groot gedeelte van de waterkolom halen. Ook binnen of in de nabijheid van MZI's kunnen voedseltekorten optreden, de zogenaamde schaduwwerking ${ }^{19}$. Om die reden mogen in Nederland de kweekpercelen niet voor $M Z I$ 's worden gebruikt, en moet er minimaal $200 \mathrm{~m}$ afstand zijn tussen MZI's en kweekpercelen ${ }^{21}$.

Over de relatie tussen MZI's en lokale voedseltekorten in hoogdynamische systemen zoals de Zeeuwse Delta en de Waddenzee is maar weinig bekend ${ }^{19,76}$. $\mathrm{Er}$ is één gerichte studie geweest op vijf MZI-locaties in Nederland ${ }^{67}$. Voor de meeste locaties zijn er geen verschillen gevonden in mosselproductie in het midden en aan de randen van de systemen. Alleen in het Gat van Stompe (Waddenzee) hebben mosselen aan de rand van het $M Z I$-systeem een betere conditie. De studie bevestigt dat, net als in andere hangcultuur kweeksystemen, ook in MZI's verminderde voedselbeschikbaarheid en mosselgroei kunnen optreden ${ }^{19,67}$. Dit betekent dat er lokale draagkrachteffecten kunnen ontstaan. Het is echter niet aannemelijk dat dit op grote schaal gebeurt. Dit is omdat de meeste MZI's op plekken liggen waar de stroming, en dus waterverversing, hoog is.
Internationaal onderzoek in gebieden met een lage natuurlijke dynamiek laat zien dat in hangcultures voor consumptiemosselen lokale voedseltekorten in het midden van de systemen kunnen ontstaan ${ }^{19}$. Dit komt omdat de systemen weerstand uitoefenen op het instromende water. Dit zorgt vervolgens tot een afname in de stroomsnelheid. Samen met de filtratie van de mosselen kunnen die verminderde stroomsnelheden tot afname van het voedselaanbod binnen het systeem leiden. Dat leidt weer tot ruimtelijke verschillen in groeisnelheid, met tragere groei in het midden en betere groei aan de randen. Een kweker kan door een goede inrichting van de systemen invloed hierop uitoefenen ${ }^{19}$.
Beheer

Biodiversiteit

\section{Draagkracht}

Bestand

Draagkracht

ecosysteem

\section{Draagkracht lokaal}
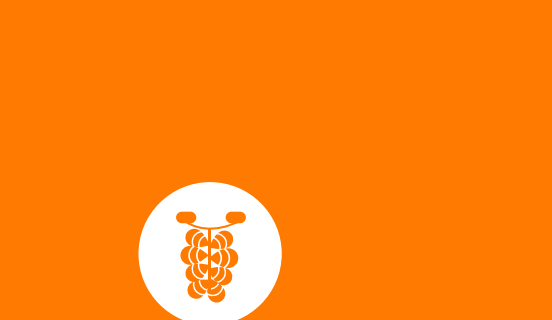


\section{Hoe worden mosselen gekweekt?}

Het mosselzaad van wilde zaadbanken of mosselzaadinvang installaties (MZI's) gaat naar kweekpercelen in het sublitoraal van de Waddenzee en Oosterschelde. Een klein deel van de kweek gebeurt in hangcultures in de Oosterschelde, Grevelingen en Veerse Meer. Op de kweekpercelen groeit het zaad door een natuurlijk proces uit tot consumptiemosselen de mosselen filteren voedingsstoffen uit het water. Het hele kweekproces duurt anderhalf tot twee jaar. Tijdens het kweken worden de mosselen nog 1 of 2 keer opgevist en verplaatst naar andere percelen, zodat ze optimaal kunnen groeien. Ook nemen kwekers maatregelen om plagen van zeesterren, die mosselen eten, onder controle te houden (dweilen). Hoewel de kwekers zelf enige invloed kunnen uitoefenen op het groeiproces, speelt de natuur uiteindelijk een grote rol in de opbrengst ${ }^{23}$

Mosselzaad spoelt gemakkelijk weg en moet zich dus vasthechten aan substraat of aan elkaar om te overleven. Op natuurlijke banken vormt het mosselzaad een matrix: ze hechten zich aan elkaar en aan dood schelpmateriaal dat op de bodem ligt. Dood schelpmateriaal fungeert als verankering in de bodem ${ }^{24}$. Dit ontbreekt bij MZI-zaad, want dit wordt bij de oogst van de touwen of netten afgeborsteld. Na het zaaien aggregeert MZI-zaad sneller en hecht zich vaster dan bodemzaad ${ }^{25}$. MZI-zaad heeft daarom behoefte aan percelen met veel los schelpmateriaal ('gruizige grond'). Daarnaast is de praktijkervaring van kwekers dat zich onder het uitgezaaid MZI-zaad over de tijd meer slib ophoopt, waardoor het MZI-zaad instabieler is dan bodemzaad en eerder wegspoelt bij harde stroming of storm ${ }^{17}$. MZI-zaad is daarom gebaat bij percelen waar het niet te hard stroomt of die niet op stormgevoelige locaties liggen.

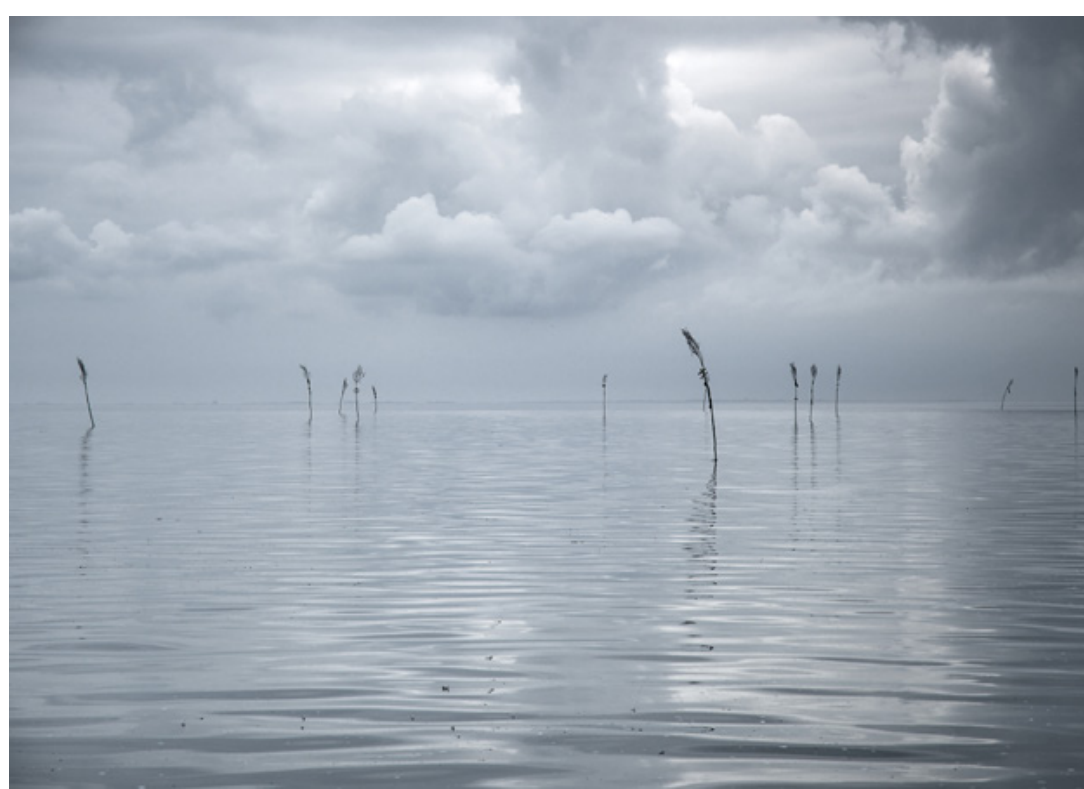

De groei van mosselen op percelen laat veel variatie zien. Meerjarige metingen tonen aan dat de groei hoger is naarmate de percelen dichter bij de Noordzee liggen. Dit is zowel in de Oosterschelde als in de Waddenzee het geval. $\mathrm{Na}$ voortplanting van de mosselen in het voorjaar is de groe het hoogst in de Oosterschelde, waar de groei na juli weer afneemt. In de Waddenzee groeien de mosselen langer door, tot in oktober ${ }^{26}$.

Als de mosselen uitgegroeid zijn tot consumptiemaat worden ze opgevist. Via de mosselveiling in Yerseke veranderen ze van eigenaar. Voordat ze bij de consumenten terechtkomen, moeten de mosselen zichzelf schoon filteren van slibresten. Dit gebeurt door ze eerst een tijdje op speciale percelen in de Oosterschelde te leggen, of in bassins op het land.
Kweekpercelen

\section{Beheer}

Praktijk

Beheermaatregelen

Bestand

Biodiversiteit

\section{Draagkracht}

\section{Sediment}

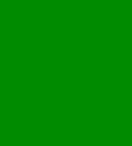




\section{Welke beheermaatregelen gelden er voor de mosselpercelen?}

De kwekers pachten de percelen van de overheid. Niet alle percelen zijn even geschikt voor kweek. Sommigen worden gebruikt voor opslag, anderen voor uitgroei van zaad naar halfwas of van halfwas naar consumptie. Op percelen in de Waddenzee is de groei gemiddeld beter dan in de Oosterschelde $^{26}$. Wel zijn de percelen op het wad minder beschut en daardoor instabieler ${ }^{27}$. Hierdoor kunnen verliezen door stormschade groter zijn.

De ervaring van de kwekers is dat MZI-zaad minder geschikt is voor percelen met veel stroming. Zij wijten dit aan de grotere hoeveelheid slib die $M Z I$-mosselen zouden produceren $^{17}$. Hoewel dit niet is onderzocht, is dit wel een waarschijnlijke verklaring: MZI-zaad is over het algemeen kleiner bij het zaaien dan bodemzaad. Daarom is de zaai-dichtheid groter. Bovendien nemen MZI-mosselen, omdat zij niet zijn aangepast aan slibrijke voedselcondities, in eerste instantie minder efficiënt voedsel op. Samen leidt dit tot een hogere slibproductie. Indien mogelijk houden kwekers hier in hun uitzaai-strategie rekening mee ${ }^{17}$.

Hoe meer consumptiemosselen uit een kilo mosselzaad komen, hoe beter het kweekrendement is. Door geleidelijke verzanding en verplaatsing van stroomgeulen neemt de kwaliteit van percelen af en daarmee het kweekrendement ${ }^{27}$ In 1995 zijn voor het laatst nieuwe locaties voor kweekpercelen uitgegeven (optimalisatie). Vanuit het Mosse/convenant $^{11}$ is in 2021 weer een optimalisatie uitgevoerd. Als onderdeel daarvan loopt het onderzoek 'evaluatie nieuwe percelen': de aanleg van nieuwe percelen biedt immers de unieke situatie om te bekijken hoe de biodiversiteit in een gebied verandert ${ }^{28}$.

\section{Beheer}

Praktijk

Beheermaatregelen

Bestand

Biodiversiteit

Draagkracht

Sediment

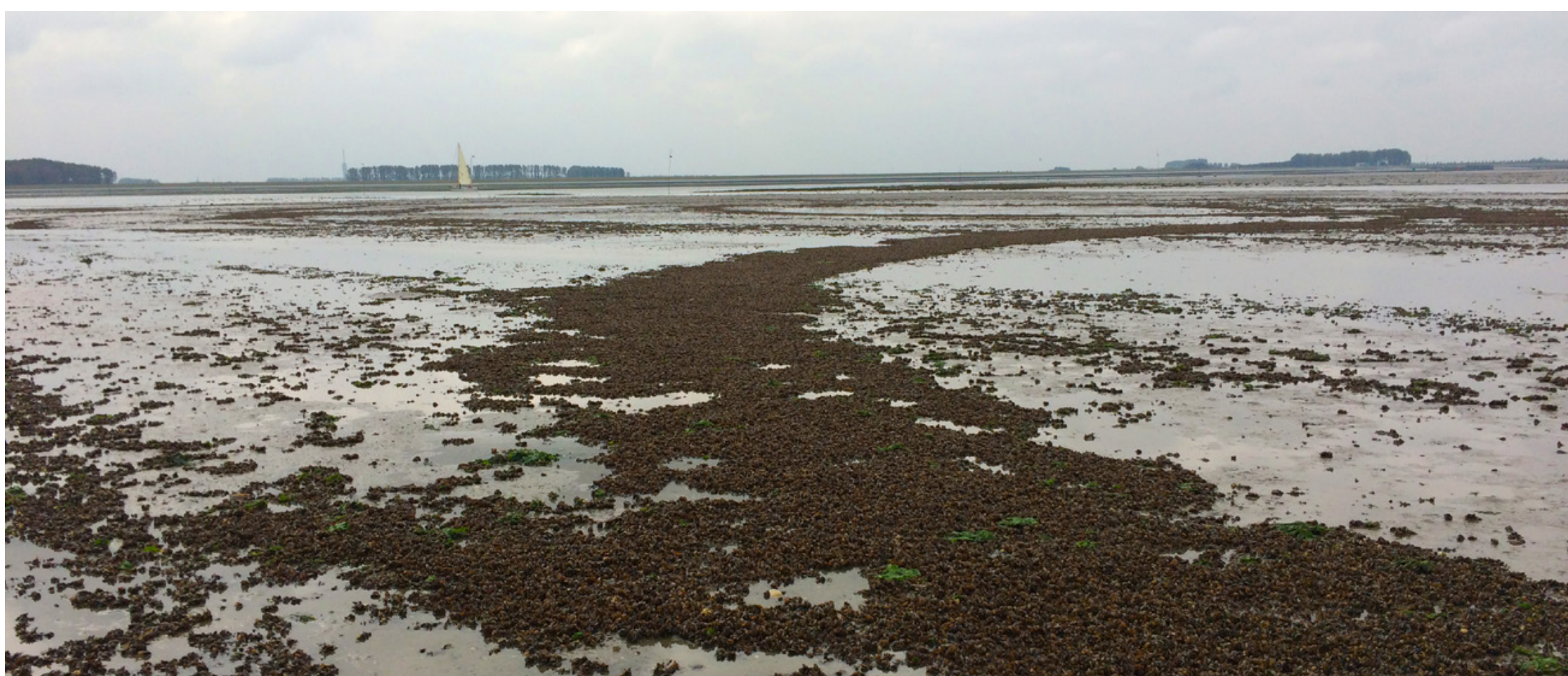

\section{(1)}




\section{Hoe zit het met de hoeveelheid mosselen op de kweekpercelen?}

\section{Kweekpercelen}

In het schelpdiervisserijbeleid is vastgelegd dat ieder najaar een minimale hoeveelheid mosselen op de percelen aanwezig dient te zijn. Zo wordt voldaan aan de voorwaarde dat het geheel van vissen, kweken en oogst van consumptiemosselen niet leidt tot minder mosselen in de Waddenzee, vergeleken met een situatie zonder visserij. Hiervoor is het zogenaamde Vissen, Kweken en Afvoeren (VKA)-rekenmode ontwikkeld ${ }^{9}$. Onderzoek laat zien dat voor de langere termijn de mosselkweek tot meer biomassa aan mosselen leidt dan in een situatie waarin er geen kweek zou zijn ${ }^{29,30}$. Over de periode 2004-2012 zijn er door de kweek van mosselen, inclusief MZI-gebruik, ongeveer $27 \%$ meer mosselen in de westelijke Waddenzee dan in een situatie zonder kweek; dit ondanks de oogst en afvoer van mosselen ${ }^{30}$. Dit komt omdat mosselen op de percelen een betere groei en overleving hebben vergeleken met op wilde mosselbanken ${ }^{31}$. Bovendien worden kweekpercelen over het algemeen niet aangelegd op plekken waar zich van nature wilde mosselbanken vormen.

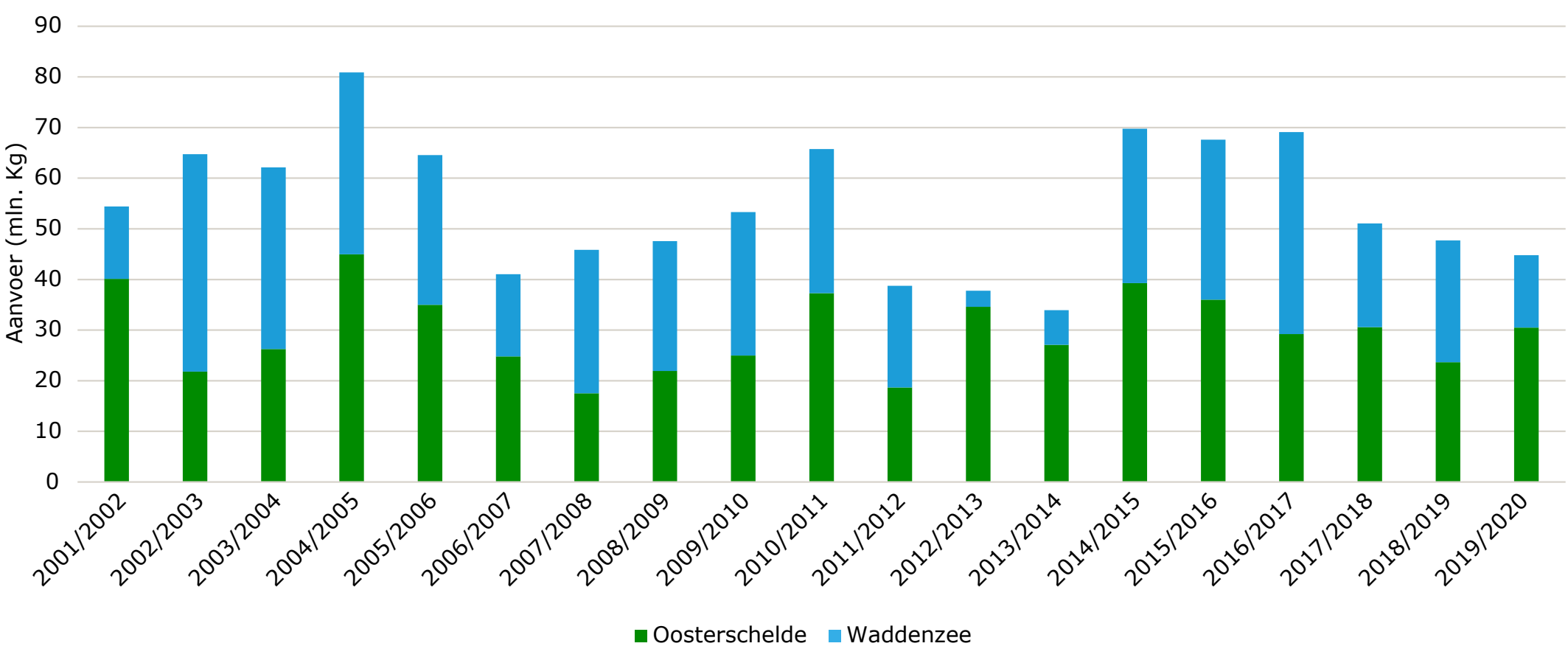

Aanvoer Nederlandse consumptiemosselen, seizoen 2001/2002-2018/2020, inclusief verkopen buiten de klok.

Gegevens: Mosselkantoor; PO Mosselcultuur. 


\section{Zijn er verschillen in de bodemdierengemeenschap op wilde mosselbanken en op de kweekpercelen?}

De mosselen op de kweekpercelen spelen grotendeels dezelfde rol als op wilde mosselbanken; ze dragen bij aan een hoge biodiversiteit, verbeteren de waterkwaliteit, en bepalen gezamenlijk de draagkracht voor schelpdieren van het ecosysteem.

De biodiversiteit op mosselkweekpercelen verschilt niet wezenlijk van die op sublitorale mosselbanken. Beide hebben een relatieve hoge biodiversiteit. Op de wilde mosselbanken in het sublitoraal zijn in een grootschalige studie gemiddeld 84 verschillende soorten aangetroffen; op de percelen gemiddeld $102^{32}$. Er zijn twee verklaringen voor het verschil in aantallen soorten. Ten eerste komen wilde banken over het algemeen bij lagere zoutgehaltes voor, terwijl de kweek percelen vooral in gebieden met relatief hoge zoutgehaltes liggen. Het onderzoek laat zien dat de biodiversiteit groter is bij hogere zoutgehaltes. Wanneer wilde banken en kweek- percelen worden vergeleken die wél vlak bij elkaar liggen, dan blijkt juist het aantal soorten in de wilde banken iets hoger te zijn. Ten tweede houden de mosselkwekers de percelen zo veel mogelijk schoon van zeesterren, die mosselen en geassocieerde soorten opeten ${ }^{32}$.

Op de kweekpercelen bestaat een duidelijk verband tussen de mosselen en de biodiversiteit; hoe meer mosselen, hoe meer andere soorten ${ }^{43,57}$. Op de kweekpercelen zijn weliswaar meer verschillende soorten aanwezig, maar op de wilde banken komen deze geassocieerde soorten juist vaker voor. Het gaat dan vooral over soorten die voorkomen op zacht substraat zoals zanderige bodems (bijvoorbeeld de groene zeeduizendpoot, de strandgaper en het wadslakje). Soorten die juist meer voorkomen op de kweekpercelen zijn o.a. de Amerikaanse zwaardschede, de zeester en mosdiertjes ${ }^{32}$.

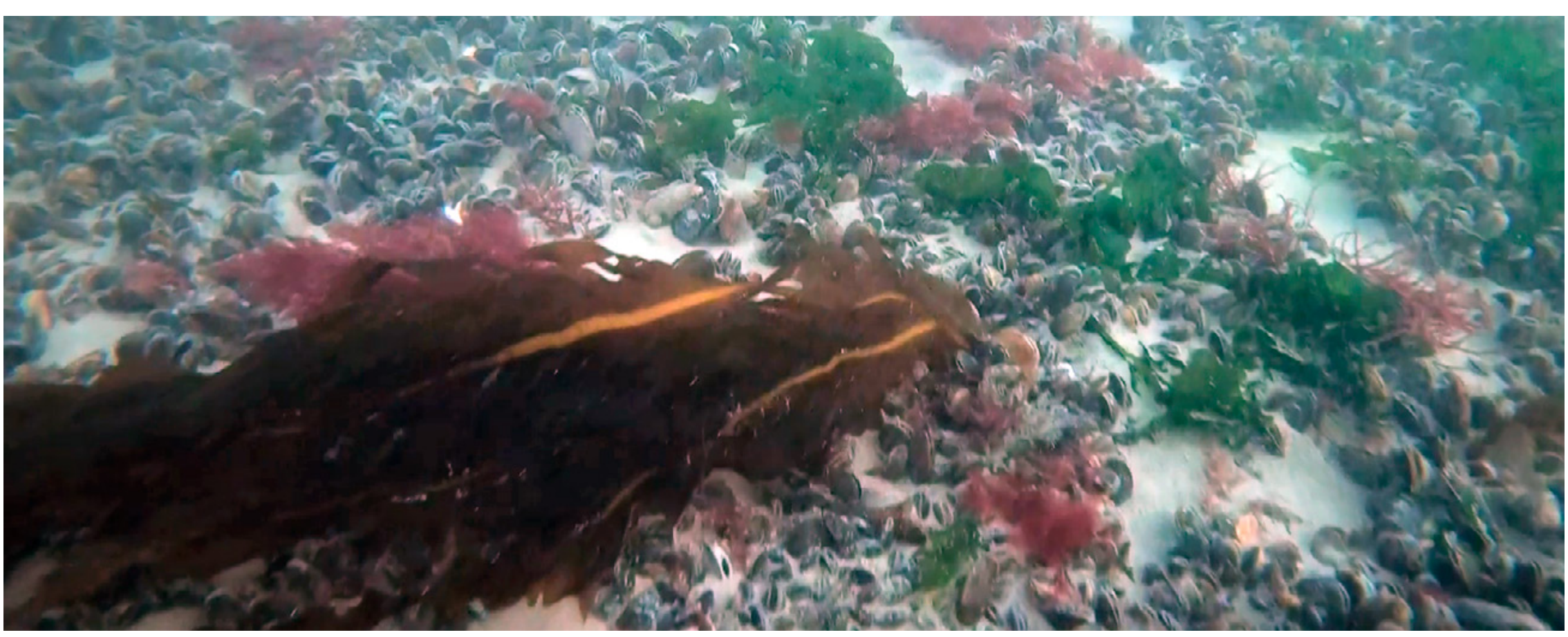

Beheer

\section{Biodiversiteit}

Samenstelling bodemdieren

Nieuwe percelen

Vogels

\section{Draagkracht}

\section{Sediment}

\section{(i)}




\section{Zijn er veranderingen in de biodiversiteit na de aanleg van nieuwe kweekpercelen?}

\section{Kweekpercelen}

In 2021 zijn nieuwe kweek percelen uitgegeven en oude percelen ingenomen (optimalisatie). Dit is een afspraak uit het Mosselconvenant ${ }^{11}$. Als onderdeel van de optimalisatie loopt het onderzoek 'evaluatie nieuwe percelen': de aanleg van nieuwe percelen biedt immers de unieke situatie om te bekijken hoe de biodiversiteit in een gebied verandert ${ }^{28}$. Dit onderzoek is nog niet afgerond.

\section{Beheer}

Biodiversiteit

Samenstelling

bodemdieren

Nieuwe percelen

Vogels

Draagkracht

\section{Sediment}

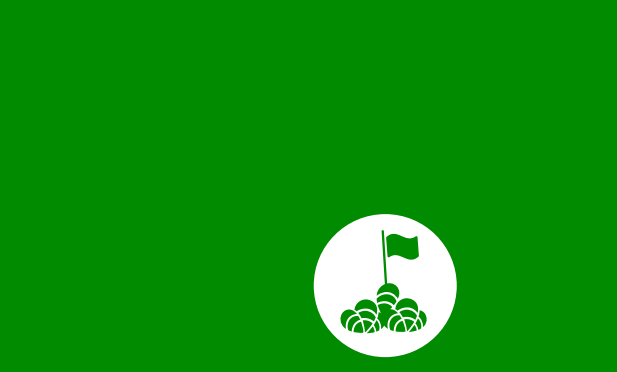




\section{Hoe belangrijk zijn de mosselen op de kweekpercelen als voedselbron voor vogels?}

De Waddenzee is van internationaal belang voor schelpdieretende vogels ${ }^{58}$. Mosselen in de sublitorale gebieden zijn voor enkele vogelsoorten belangrijk. Duikende eenden, zoals de eidereend en de topper, zijn in staat mosselen van de wilde banken en kweekpercelen in het sublitoraal te eten ${ }^{59}$. Daarbij kan het zo zijn dat soorten die duiken naar vissen die zich tussen de mosselen ophouden, ook baat hebben bij mosselbanken en -percelen, al ontbreken goede telgegevens voor deze vogelsoorten ${ }^{60}$

Het dieet van eidereenden in de Waddenzee kan, bij voldoende aanbod, voor wel $90 \%$ uit mosselen bestaan. Ze vullen dit aan met krabben, kokkels en mesheften.

Verspreidingsonderzoek laat zien dat overwinterende eidereenden een voorkeur hebben om op de kweekpercelen naar voedsel te zoeken ${ }^{37}$. Eidereenden prefereren medium tot grote mosselen in hoge dichtheden. Deze komen in de Waddenzee vooral op de kweekpercelen voor. De kweekmosselen hebben bovendien een betere vlees/schelp verhouding dan 'wilde' mosselen in de getijdezone ${ }^{61,62}$. Eidereenden hebben daarom voordeel bij de aanwezigheid van mosselpercelen ${ }^{29,37}$. Wanneer er minder mosselen op de percelen zijn schakelen ze over naar alternatief voedsel ${ }^{37}$. Ook in de loop van de winter komen de eidereenden weer vaker voo op de wilde mosselbanken. Er zijn twee mogelijke (gecombineerde) verklaringen. De eerste is dat in de winter de kwaliteit van de mosselen op de percelen afneemt en vergelijkbaar wordt met die op de wilde banken ${ }^{59}$. De tweede verklaring is dat er in de loop van de winter steeds meer mosselen van de percelen worden geoogst ${ }^{37}$

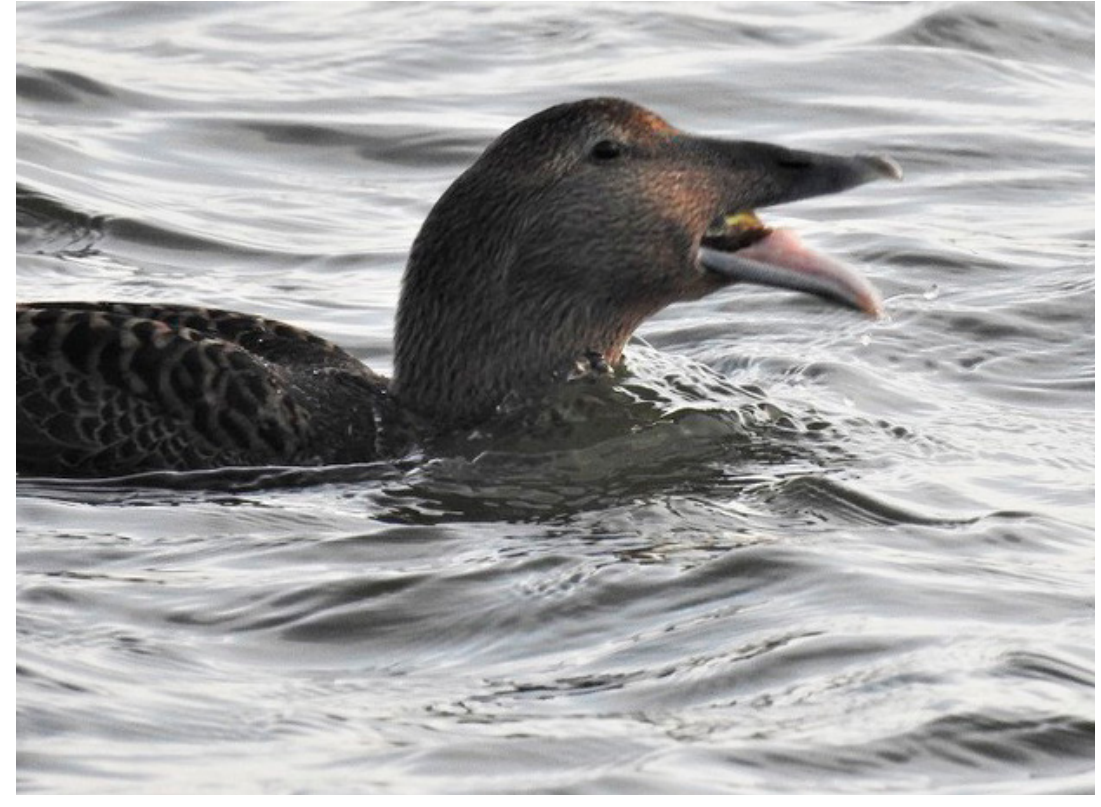

De aantallen overwinterende toppers variëren sterk tussen de jaren. In het Waddengebied worden 's winters rond de 30.000 toppers geteld ${ }^{63}$, vooral voor de Afsluitdijk waar de zoutgehaltes lager zijn ${ }^{58}$. Op de locaties in de Waddenzee waar de toppers voorkomen, zijn nauwelijks kweekpercelen aanwezig ${ }^{59}$. Uit verspreidingsonderzoek blijkt dat toppers meer voorkomen op locaties waar kleinere prooisoorten aanwezig zijn, zoals jonge strandgapers ${ }^{36}$. Mosselen hebben net als strandgapers een relatief hoge verhouding tussen vlees en schelp. Toch wordt er maar een gering verband gevonden tussen de verspreiding van mosselen en de topper Waarschijnlijk komt dit omdat mosselen met hun byssusdraden trossen vormen. Het kost de topper dan meer tijd en energie om individuele mosselen te consumeren ${ }^{36}$.
Beheer

\section{Biodiversiteit}

Samenstelling bodemdieren

Nieuwe percelen

Vogels

Draagkracht

\section{Sediment}

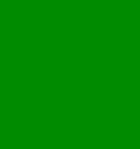




\section{Hoe zit het met de hoeveelheid mosselen op de kweekpercelen?}

\section{Kweekpercelen}

In het schelpdiervisserijbeleid is vastgelegd dat ieder najaar een minimale hoeveelheid mosselen op de percelen aanwezig dient te zijn. Zo wordt voldaan aan de voorwaarde dat het geheel van vissen, kweken en oogst van consumptiemosselen niet leidt tot minder mosselen in de Waddenzee, vergeleken met een situatie zonder visserij. Hiervoor is het zogenaamde Vissen, Kweken en Afvoeren (VKA)-rekenmode ontwikkeld ${ }^{9}$. Onderzoek laat zien dat voor de langere termijn de mosselkweek tot meer biomassa aan mosselen leidt dan in een situatie waarin er geen kweek zou zijn ${ }^{29,30}$. Over de periode 2004-2012 zijn er door de kweek van mosselen, inclusief MZI-gebruik, ongeveer $27 \%$ meer mosselen in de westelijke Waddenzee dan in een situatie zonder kweek; dit ondanks de oogst en afvoer van mosselen ${ }^{30}$. Dit komt omdat mosselen op de percelen een betere groei en overleving hebben vergeleken met op wilde mosselbanken ${ }^{31}$. Bovendien worden kweekpercelen over het algemeen niet aangelegd op plekken waar zich van nature wilde mosselbanken vormen.

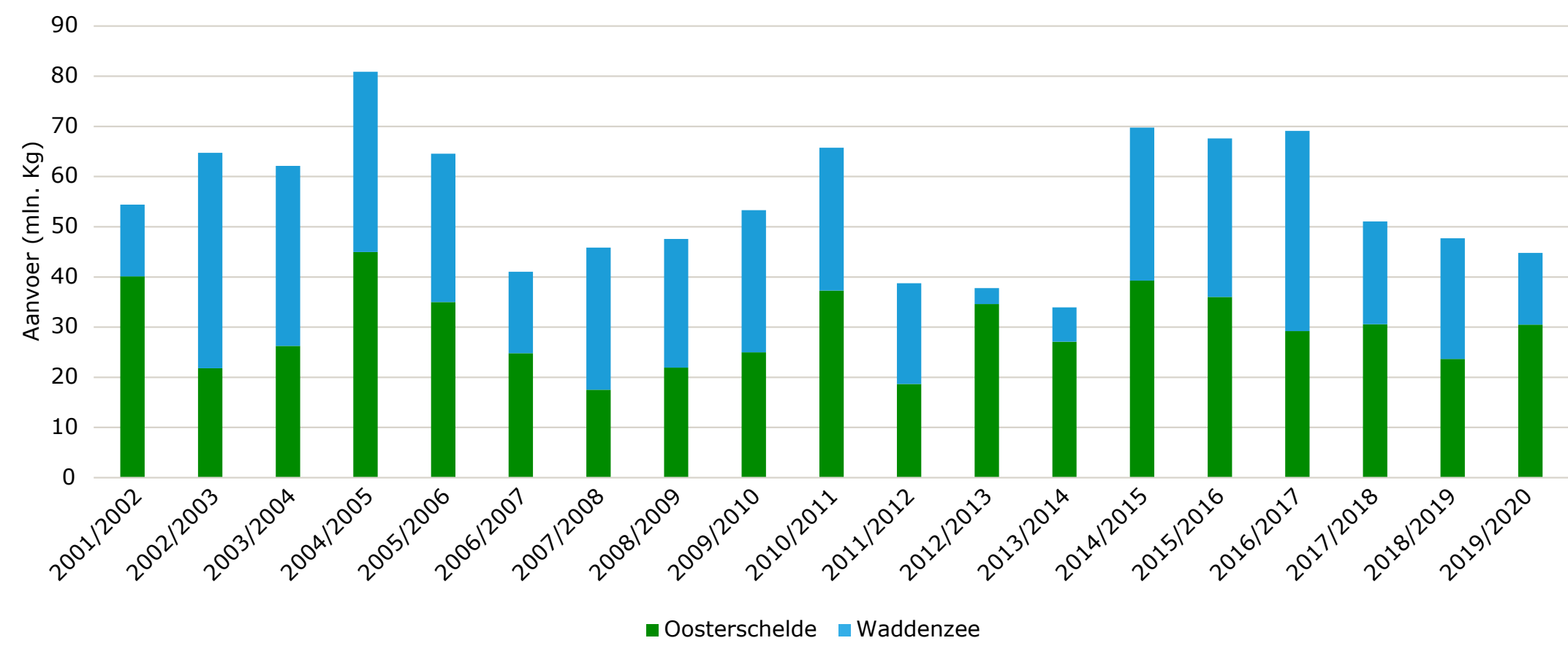

- Oosterschelde $\quad$ Waddenzee

Aanvoer Nederlandse consumptiemosselen, seizoen 2001/2002-2018/2020, inclusief verkopen buiten de klok.

Gegevens: Mosselkantoor; PO Mosselcultuur. 


\section{Welke invloed heeft mosselkweek op de draagkracht voor schelpdieren?}

\section{Kweekpercelen}

Schelpdieren voeden zich door microalgen uit het water te filteren. Wanneer er zo veel micro-algen worden gegeten dat de groei (aanwas) van de algen wordt afgeremd (overbegrazing), is het schelpdierbestand te groot. De zogenaamde draagkracht van het ecosysteem voor schelpdieren wordt dan overschreden. De schelpdieren kunnen dan niet meer optimaal groeien. Dit kan negatief doorwerken naar soorten die afhankelijk zijn van schelpdieren, zoals vogels. Gekweekte schelpdierbestanden concurreren om voedsel met natuurlijk voorkomende schelpdieren. Een optimaal evenwicht tussen natuur en productie is daarom belangrijk.

Mosselkweek draagt substantieel bij aan de omvang van het totale schelpdierenbestand en kan daarom effect hebben op de draagkracht. In de Oosterschelde vormen de kweek-

mosselen ongeveer $30 \%$ van het totale schelpdierenbestand; in de westelijke Waddenzee is dit ongeveer $20 \%{ }^{71}$. Recent onderzoek laat zien dat de draagkracht van de Oosterschelde en Waddenzee voor schelpdieren momenteel niet onder druk staat $^{71}$

Voor de Oosterschelde concluderen eerdere studies dat er voor de periode 1995-2009 aanwijzingen voor overbegrazing $z_{i j n}{ }^{72}$. Sindsdien hebben veranderingen plaatsgevonden, zoals een afname van het oesterbestand door de oester boorder en het herpesvirus. De meest recente inzichten zijn dat het totale schelpdierbestand in de Oosterschelde en daarmee de totale graasdruk (het wegfilteren van voedsel door schelpdieren) van jaar tot jaar varieert. Er zijn geen duidelijke toe- of afnemende trends. Het oesterbestand is weliswaar afgenomen, maar hierdoor is er geen substantiële daling van de graasdruk van het gehele schelpdierbestand. Er zijn geen aanwijzingen dat de huidige bestanden aan schelpdieren, inclusief de gekweekte mosselen, op dit moment directe invloed uitoefenen op de productiviteit van het

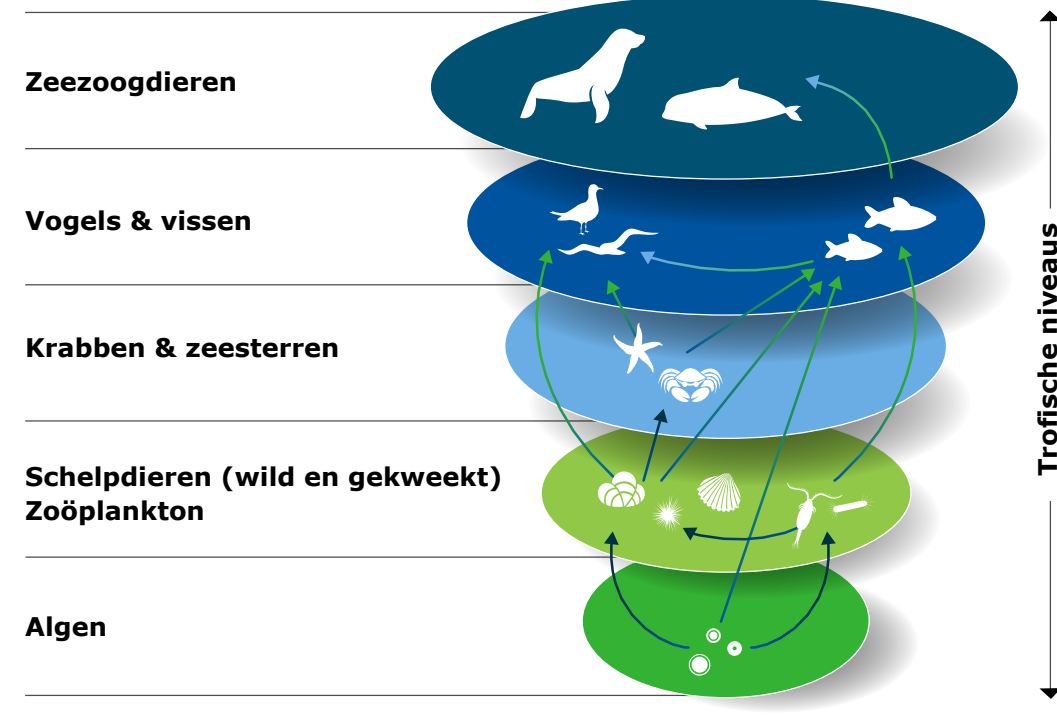

ecosysteem en het actuele voedselaanbod in de Oosterschelde. Meer schelpdieren lijken vooralsnog niet direct tot een lagere micro-algen populatie te leiden ${ }^{71}$. De groei van micro-algen populaties worden naast de begrazing door schelpdieren ('top down') bepaald door de nutriënten toevoer ('bottom up'). Hoe veranderingen in nutriëntenconcentraties de afgelopen jaren de productiviteit beïnvloed hebben, is geen onderdeel van de recente studie.

In de Waddenzee leveren niet de kweekmosselen maar andere wilde schelpdiersoorten, zoals de strandgaper, de grootste bijdrage aan de graasdruk. In de gebieden in de westelijke Waddenzee, waar de kweekpercelen liggen, is het niet waarschijnlijk dat overbegrazing optreedt; ook niet in het Marsdiep waar de (wilde) schelpdierenbestanden en de bijbehorende graasdruk sterk zijn toegenomen ${ }^{71}$. De bevinding dat de draagkracht in de westelijke Waddenzee niet overschreden wordt, komt overeen met een recente studie op Balgzand ${ }^{73}$

\section{Beheer}

Biodiversiteit

Draagkracht

Bestand

Draagkracht

ecosysteem

Draagkracht lokaal

\section{Sediment}

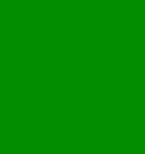




\section{Is er een relatie tussen schelpdierbiomassa en lokale draagkracht?

Als er (te) veel schelpdieren op een bepaalde plek of gebied liggen, kunnen lokaal voedseltekorten ontstaan. Dit kan gevolgen hebben voor de productie van wilde of gekweekte mosselen. Het is bekend dat de waterlaag direct boven mosselkweekpercelen een lagere voedselconcentratie kan hebben ${ }^{74,75}$. Dit is vooral het geval in gebieden met relatief lage stroming.

Mosselen in mosselzaadinvanginstallaties (MZI's) kunnen hun voedsel uit een groot gedeelte van de waterkolom halen. Ook binnen of in de nabijheid van MZI's kunnen voedseltekorten optreden, de zogenaamde schaduwwerking ${ }^{19}$. Om die reden mogen in Nederland de kweekpercelen niet voor MZI's worden gebruikt, en moet er minimaal $200 \mathrm{~m}$ afstand zijn tussen MZI's en kweekpercelen ${ }^{21}$

Over de relatie tussen $M Z I$ 's en lokale voedseltekorten in hoogdynamische systemen zoals de Zeeuwse Delta en de Waddenzee is maar weinig bekend ${ }^{19,76}$. $\mathrm{Er}$ is één gerichte studie geweest op vijf MZI-locaties in Nederland ${ }^{67}$. Voor de meeste locaties zijn er geen verschillen gevonden in mosselproductie in het midden en aan de randen van de systemen. Alleen in het Gat van Stompe (Waddenzee) hebben mosselen aan de rand van het MZI-systeem een betere conditie. De studie bevestigt dat, net als in andere hangcultuur kweeksystemen, ook in MZI's verminderde voedselbeschikbaarheid en mosselgroei kunnen optreden ${ }^{19,67}$. Dit betekent dat er lokale draagkrachteffecten kunnen ontstaan. Het is echter niet aannemelijk dat dit op grote schaal gebeurt. Dit is omdat de meeste MZI's op plekken liggen waar de stroming, en dus waterverversing, hoog is.
Internationaal onderzoek in gebieden met een lage natuurlijke dynamiek laat zien dat in hangcultures voor consumptiemosselen lokale voedseltekorten in het midden van de systemen kunnen ontstaan ${ }^{19}$. Dit komt omdat de systemen weerstand uitoefenen op het instromende water. Dit zorgt vervolgens tot een afname in de stroomsnelheid. Samen met de filtratie van de mosselen kunnen die verminderde stroomsnelheden tot afname van het voedselaanbod binnen het systeem leiden. Dat leidt weer tot ruimtelijke verschillen in groeisnelheid, met tragere groei in het midden en betere groei aan de randen. Een kweker kan door een goede inrichting van de systemen invloed hierop uitoefenen ${ }^{19}$
Beheer

Biodiversiteit

\section{Draagkracht}

Bestand

Draagkracht

ecosysteem

Draagkracht lokaal

\section{Sediment}




\section{Leidt mosselzaadvisserij en -kweek tot vertroebeling van het water door opwerveling van sediment?}

\section{Kweekpercelen}

De Waddenzee kent van nature grote sedimenttransporten. Verhoogde vertroebeling en sedimentatie kunnen gevolgen hebben voor het ecosysteem. Naast natuurlijke oorzaken kunnen ook menselijke activiteiten, zoals baggeren, kustverdediging en bodemvisserij, van invloed zijn op de sedimenthuishouding ${ }^{69,70}$. In 2017 is de sedimentdynamiek rond beviste mosselzaadbanken en in de directe omgeving van mosselpercelen onderzocht. De onderzoekslocaties zijn zo gekozen dat de hoogst mogelijke effecten gemeten konden worden (bijvoorbeeld hele slikkige gebieden of gebieden met hoge visserij-intensiteit) ${ }^{69}$.

In de gebieden waar wordt gevist of geoogst, wordt het water tijdelijk troebeler. De grootte van de sedimentpluim (zichtbaar opgewoeld sediment) blijft beperkt tot de directe omgeving van de mosselzaadvisserij of het oogsten van de percelen (binnen enkele tientallen tot honderd meters). De troebelheidsmetingen laten zien dat de sedimentpluim vrijwel direct na het vissen verdwijnt ${ }^{69}$. Dit duidt er op dat veel van het opgewoelde sediment direct weer op of in de nabijheid van het perceel of op de zaadbank neervalt.

De gemeten troebelheid door visserij op zaadbanken en percelen verschilt per gebied en per activiteit. Dit komt door (combinaties van) verschillende factoren, zoals visserijintensiteit, type activiteit (zaadvisserij versus oogsten, of schoonvissen, waarbij voor de nieuwe kweekcyclus zoveel mogelijk slib wordt verwijderd van het perceel), sedimenttype, diepte, stromingspatronen, wind, golven, en seizoen. De hoogste troebelheidswaarde is gevonden tijdens de mosselzaadvisserij. Tussen meerdere vissende schepen is tot maximaal 40x hogere concentraties gemeten ten opzichte van achtergrondwaardes. Bij de oogst op de kweekpercelen is maximaal een $8 \mathrm{x}$ hogere concentratie gemeten ten opzichte van de achtergrondwaardes. Deze maximale waarden zijn

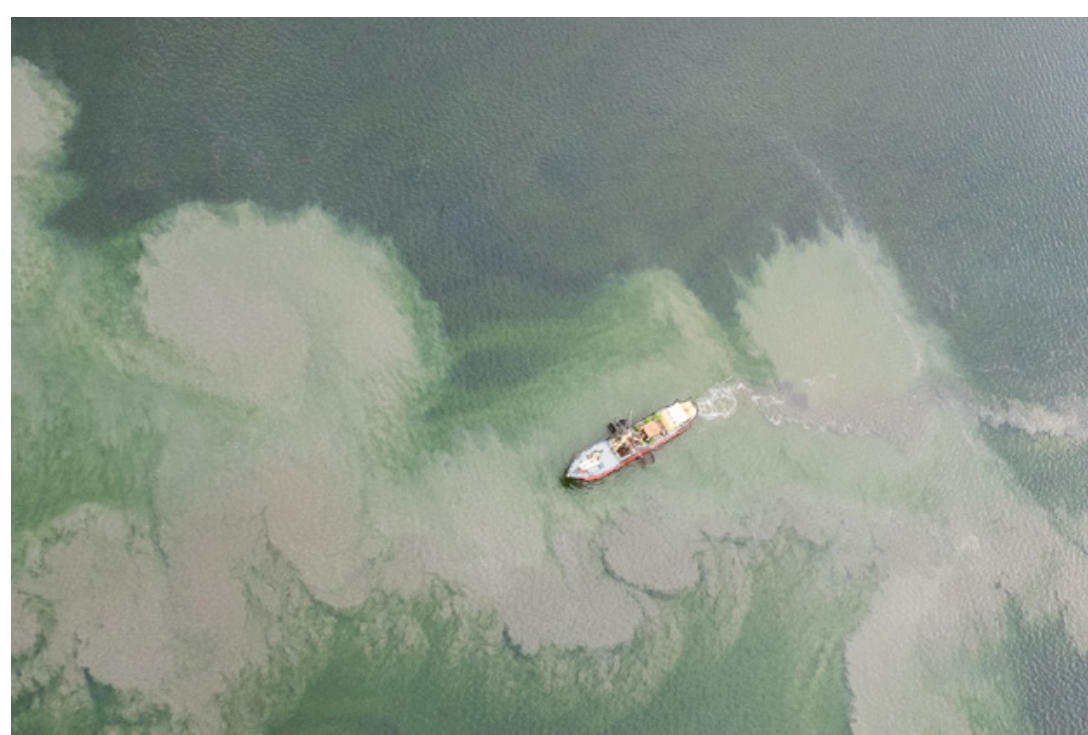

Beheer

Biodiversiteit

Draagkracht

\section{Sediment}

Vertroebeling

voor zowel de zaadvisserij en de oogst op de percelen hoger dan de hoogste meetwaarden in de langjarige monitoringprogramma's van de gehalten zwevend materiaal in de geulen. Deze langjarige monitoring vindt om technische reden echter niet plaats tijdens stormen. Dit is juist de periode wanneer de natuurlijke slibwaarden (en dus de gehalten zwevend materiaal) het hoogst zijn ${ }^{69}$.

De rol van mosselen in de sedimentdynamiek kent twee kanten. Mosselen filteren continue zwevend materiaal uit de waterkolom en leggen dit vast in mosselweefsel door groei, of als (pseudo)feces op de bodem. De filtratie zorgt voor een helderdere waterkolom, met een positief effect op de waterkwaliteit. Het onderzoek laat zien dat de visserij bodemmateriaal op wervelt. Hierdoor kan de troebelheid kortstondig en lokaal sterk toenemen op het moment dat de mosselen worden opgevist. Deze effecten van visserijactiviteiten zijn kortdurend (alleen tijdens de activiteit zelf), terwijl de effecten van filtratie continu plaatsvinden ${ }^{69}$.
(⿻) 0083 


\section{Waarom zijn wilde mosselbanken belangrijk?}

Wilde mosselbanken spelen een belangrijke rol in het ecosysteem. Ze vormen structuren en leefruimte voor andere soorten, die op en tussen de mosselen leven ${ }^{32-34}$. Denk bijvoorbeeld aan andere schelpdieren, krabbetjes, zeesterren, sponzen, anemonen, pokken en wormen. Dit worden ook wel geassocieerde soorten genoemd. Ook leveren wilde mosselbanken voedsel voor schelpdieretende vogels en vogels die leven van organismen die in de mosselbanken voorkomen ${ }^{35-37}$. Mosselbanken zijn dus van groot belang voor de biodiversiteit, en vormen een belangrijke schakel in het voedselweb ${ }^{6,38}$. Mosselen op kweekpercelen vervullen grotendeels dezelfde rol als mosselen op wilde banken ${ }^{32}$.

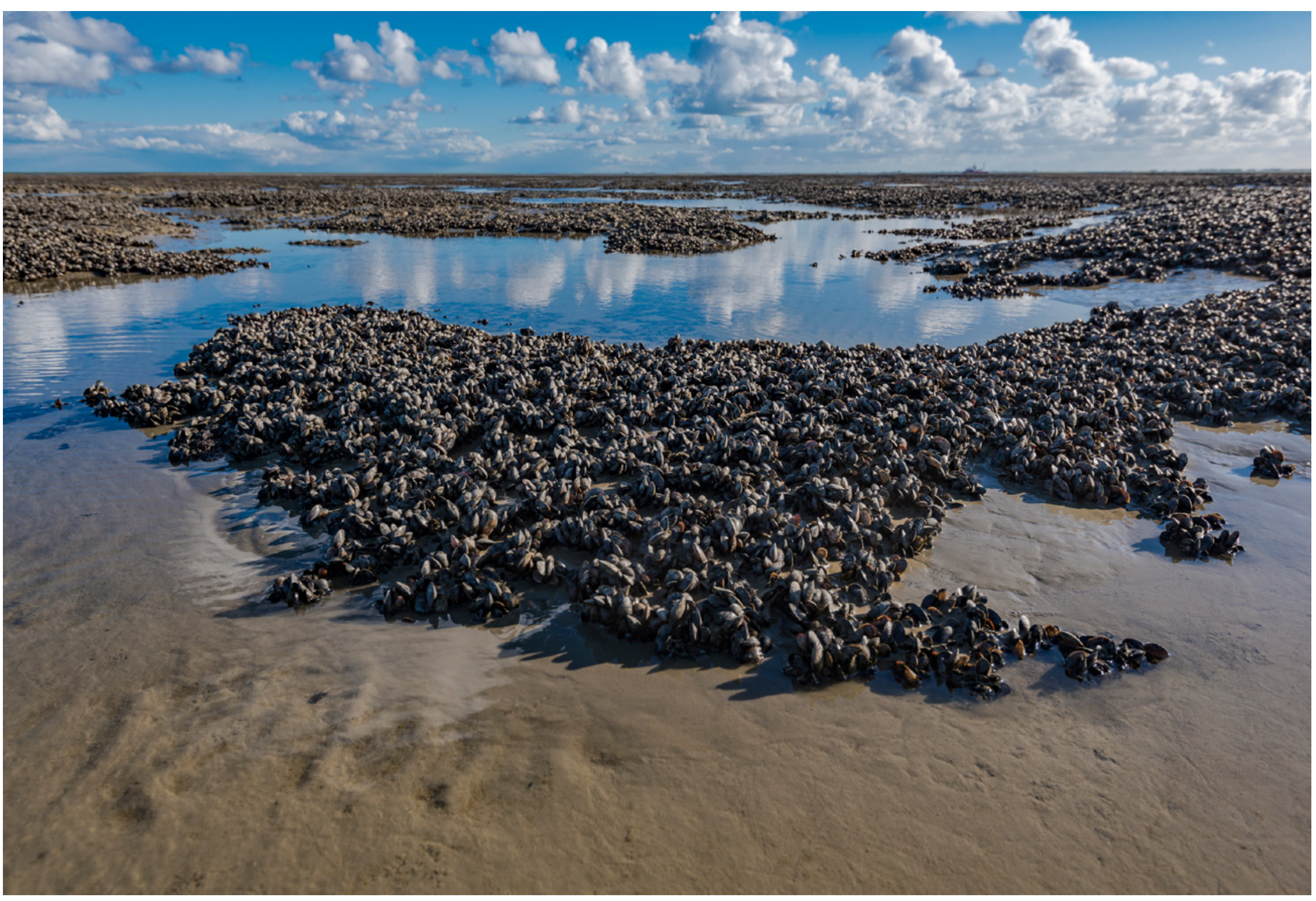

Wilde

mosselbanken

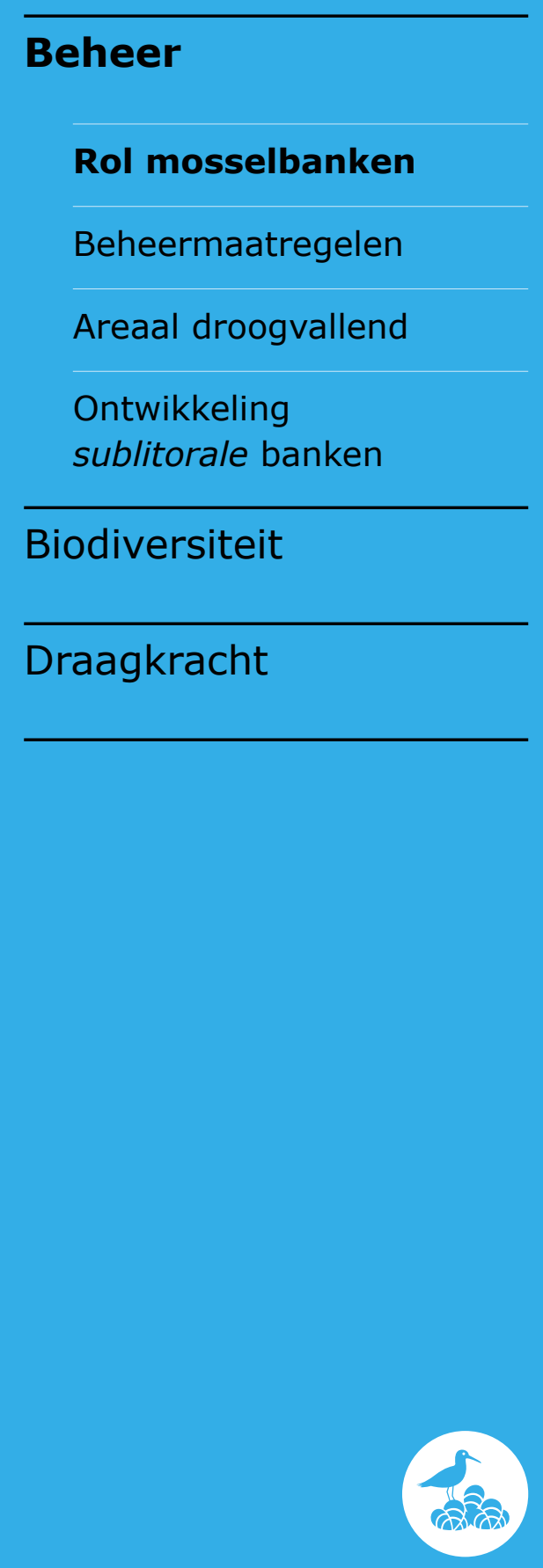




\section{Welke beheermaatregelen gelden voor de wilde mosselbanken?}

Wilde mosselbanken zijn in de Waddenzee te vinden op de wadplaten in het droogvallende gebied (het litoraal) en het deel dat altijd onder water staat (het sublitoraal). Het grootste areaal aan litorale mosselbanken wordt aangetroffen in het oosten van de Nederlandse Waddenzee ${ }^{13}$, en het aangrenzende Nedersaksen in Duitsland ${ }^{39}$. Op de platen van de Oosterschelde komen al decennia geen wilde mosselbanken meer voor. Delen van het litoraal in beide gebieden zijn in de jaren '90 gesloten voor mosselzaadvisserij. Sindsdien mag alleen onder strikte voorwaarden een vergunning aangevraagd worden voor zaadvisserij in het overige gebied van het litoraal. In de praktijk is er vanaf 2001 geen litorale mosselzaadvisserij meer geweest. De laatste bevissing van litorale banken in de Waddenzee betrof een experimentele onderzoeksvisserij ${ }^{8}$.
Mosselbanken in het sublitoraal van de westelijke Waddenzee (Marsdiep en Vliestroom), met uitzondering van het Eierlandse Gat, mogen worden bevist voor zover ze buiten de aangewezen gesloten gebieden liggen. In de zeldzaam voorkomende gevallen dat er voldoende zaadval is in de Oosterschelde en Voordelta mag ook daar gevist worden. Het quotum wordt gebaseerd op de jaarlijkse inventarisatie van het mosselbestand ${ }^{13,15}$, en vastgelegd in het visplan dat door de sector wordt opgesteld. Dit visplan wordt ter goedkeuring voorgelegd aan het ministerie van Landbouw, Natuur en Voedselkwaliteit.

De afgelopen decennia is er veel onderzoek geweest naar de ontwikkeling van de litorale mosselbanken, de effecten van de zaadvisserij op de sublitorale mosselbanken ${ }^{40-44}$, en de effecten van het sluiten van sublitorale gebieden voor de visserij ${ }^{6,45}$

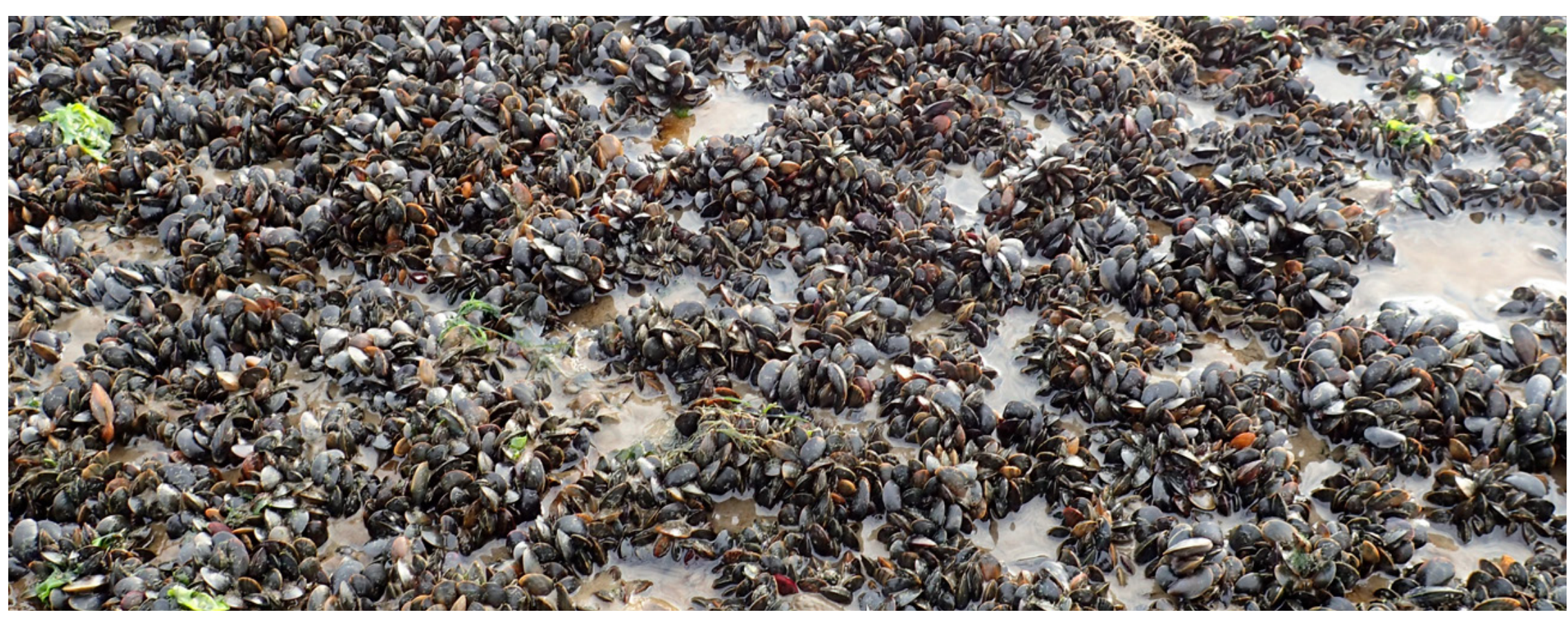

Wilde

mosselbanken

\section{Beheer}

Rol mosselbanken

Beheermaatregelen

Areaal droogvallend

Ontwikkeling

sublitorale banken

Biodiversiteit

\section{Draagkracht}

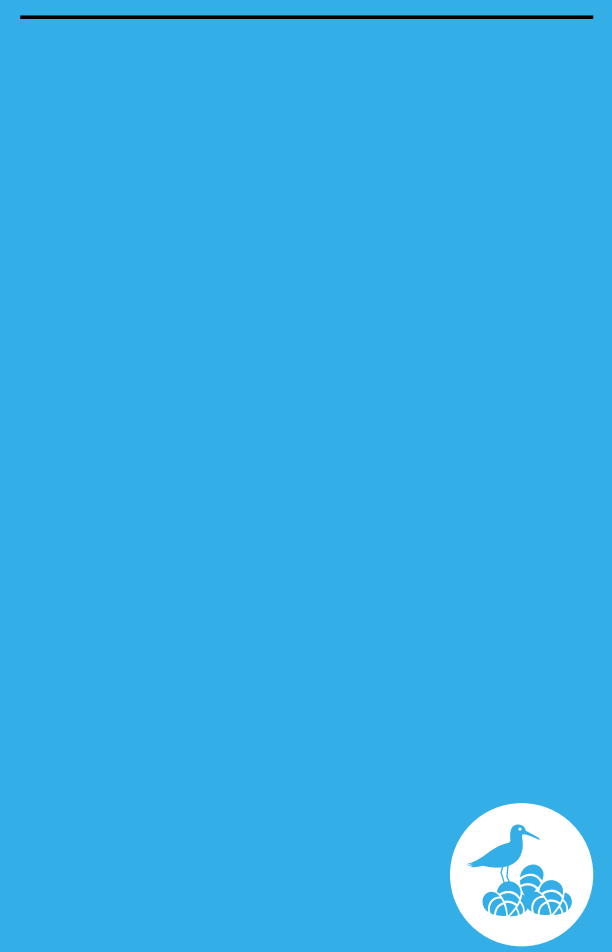




\section{Hoe ontwikkelt het areaal droogvallende wilde mosselbanken zich?}

Mosselbanken ontstaan door de jaren heen vaak op dezelfde plekken ${ }^{46,47}$. Vooral op de meer beschutte locaties kunnen ze meerdere jaren blijven bestaan. Dit komt door een combinatie van beschutting tegen wegspoelen en tussentijdse nieuwe zaadval in dezelfde bank ${ }^{6,48}$

In de Nederlandse Waddenzee ligt jaarlijks tussen de 1500 en 3900 hectare aan droogvallende mosselbanken ${ }^{14}$; in het sublitoraal tussen de 600 en 2800 hectare $^{42,45}$. Tussen jaren kan dit areaal sterk verschillen ${ }^{14}$. Dit komt aan de ene kant doordat in sommige jaren een massale zaadval optreedt.

Aan de andere kant is de overlevingskans van een mosselbank laag ${ }^{49}$. Op de droogvallende platen kunnen door stormen en golfwerking gedurende de winter veel mosselbanken verdwijnen ${ }^{49,50}$. In het sublitoraal spelen stormen waarschijnlijk ook een rol, en verdwijnen daarnaast veel mosselbanken door zeesterren ${ }^{6,51,52}$. Zeesterren kunnen massaal voorkomen op mosselbanken en deze helemaal opeten ${ }^{53}$.

Ieder jaar zijn er veel mossellarven in het water te vinden. Maar het is niet zo dat ieder jaar een succesvolle zaadval kent. Daarvoor moeten meerdere omstandigheden gunstig zijn, zoals voldoende voedsel, een gunstige temperatuur en weinig roofdieren ${ }^{6}$. Vervolgens is de kans dat een nieuwe zaadbank de eerste winter overleeft, klein. Van de droogvallende banken verdwijnt al tijdens de eerste winter gemiddeld $40 \%{ }^{6}$. Hiervan overleeft uiteindelijk ongeveer $15 \%$ tot een leeftijd van 5 jaar. Daarna worden de kansen op overleving groter $^{42}$. Banken die de eerste winter hebben overleefd, leven daarna nog gemiddeld 3 tot 4 jaar ${ }^{42}$. Ter vergelijking: de overlevingskansen van mosselbanken in het sublitoraal zijn kleiner. Van de sublitorale banken overleeft ongeveer $27 \%$ de eerste winter. Er zijn daarbij geen verschillen tussen beviste en onbeviste banken ${ }^{44}$. Sublitorale banken die de eerste winter hebben overleefd, leven daarna nog gemiddeld

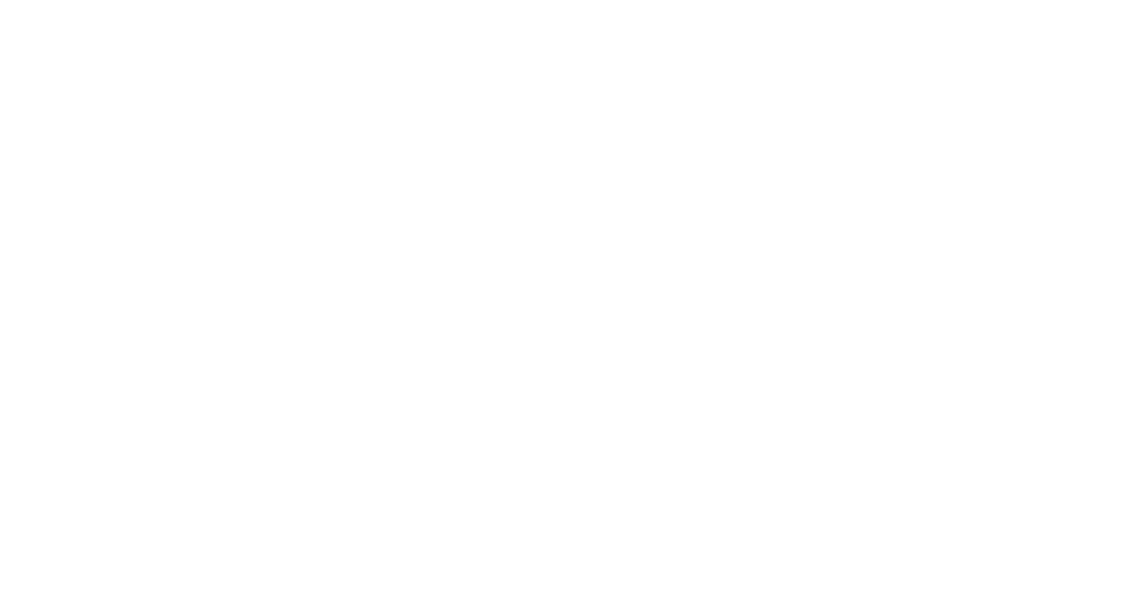

Areaal litorale mosselbanken Waddenzee 1995-2018.

Brongegevens: Wageningen Marine Research.

2 tot 3 jaar. Ook in het sublitoraal neemt de overlevingskans toe na de eerste vijf jaar ${ }^{54}$. In het sublitoraal is de overleving van mosselbanken hoger in gebieden met een laag zoutgehalte, waarschijnlijk omdat daar minder zeesterren voorkomen $^{31,52}$.

In de Waddenzee komen sinds 2002 ook Japanse oesters voor in de mosselbanken. Tegenwoordig bestaat tussen de $33 \%$ en $69 \%$ van de litorale banken uit pure mosselbanken. De rest zijn gemengde banken waarin ook Japanse oesters voorkomen ${ }^{14}$. Japanse oesters hebben een stabiliserende werking en vergroten de overlevingskansen van een litorale mosselbank ${ }^{42}$. Dit kan ten koste gaan van de beschikbaarheid van mosselen als voedselbron voor vogels zoals de scholekster ${ }^{55,56}$.

In de Oosterschelde worden al decennia lang geen wilde mosselbanken aangetroffen, maar komen mosselen wel voor in Japanse oesterbanken ${ }^{14}$.

\section{Beheer}

Rol mosselbanken

Beheermaatregelen

Areaal droogvallend

Ontwikkeling

sublitorale banken

\section{Biodiversiteit}

\section{Draagkracht}

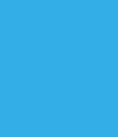




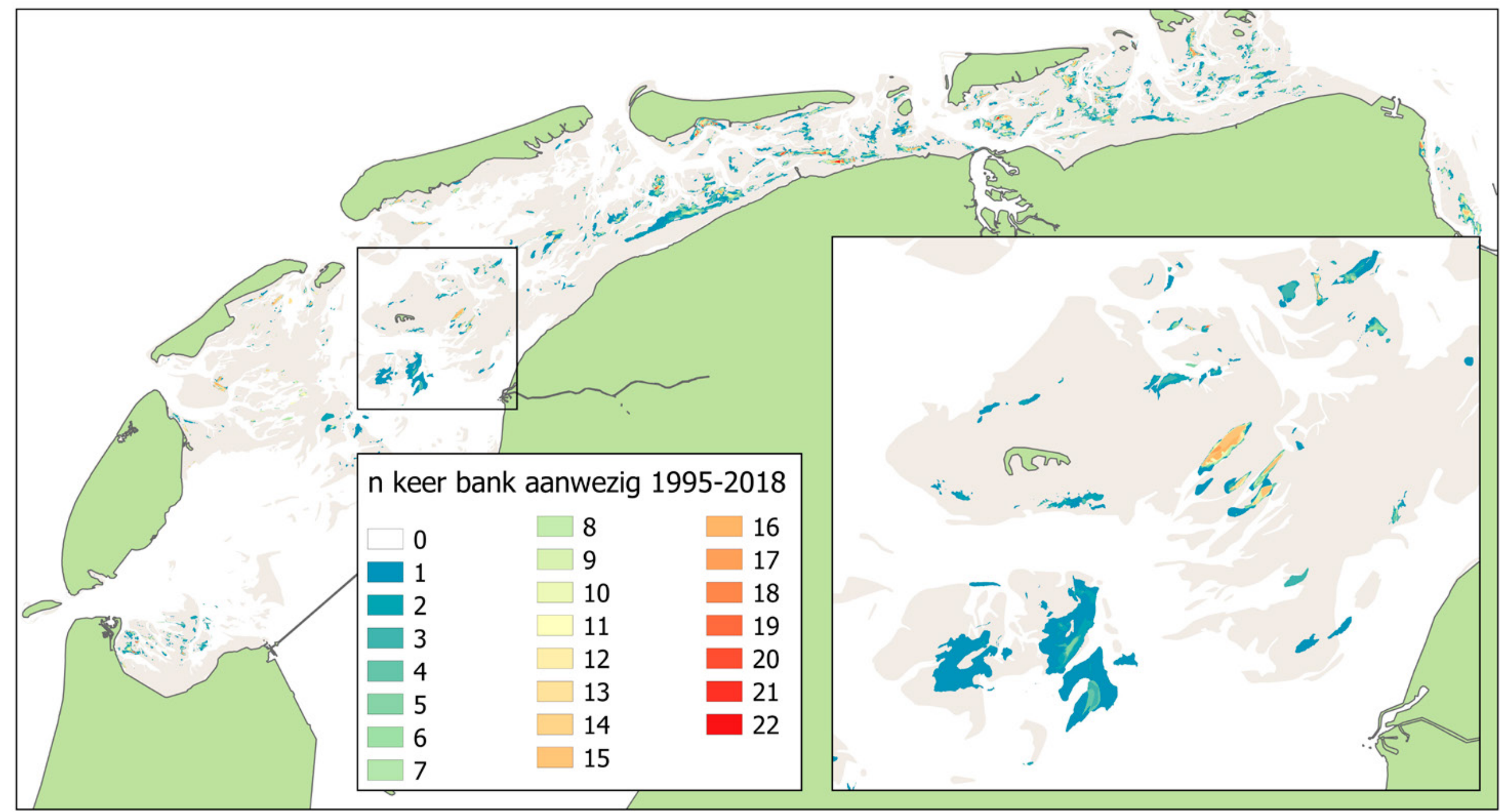

Areaal litorale mosselbanken Waddenzee 1995-2018. Brongegevens: Wageningen Marine Research.

\section{Wilde}

\section{mosselbanken}

\section{Beheer}

Rol mosselbanken

Beheermaatregelen

\section{Areaal droogvallend}

Ontwikkeling

sublitorale banken

\section{Biodiversiteit}

\section{Draagkracht}

\section{(n)}




\section{Hoe ontwikkelt het areaal aan sublitorale mosselbanken zich?}

Sinds 1992 worden mosselen in het sublitoraal van de westelijke Waddenzee jaarlijks tweemaal geïnventariseerd, in het voorjaar en in het najaar ${ }^{13}$. Met deze gegevens worden ieder jaar verspreidingskaarten gemaakt. Uit een vergelijking van de jaarlijkse verspreidingskaarten blijkt in welke gebieden vaak mosselzaad valt, en in welke gebieden dit mosselzaad vaak wel, of juist niet, overleeft. Deze informatie is verwerkt in de zogeheten "ervaringskaart" (stabilititeitskaart). In deze kaart is ook veldexpertise van vissers, visserijkundig ambtenaren en onderzoekers verwerkt. De kaart laat zien in welke gebieden de kans dat mosselzaad de eerste winter overleeft als hoog of juist laag wordt ingeschat. De kaart wordt gebruikt als basis voor de mosselzaadvisserij in het najaar, wanneer op instabiele banken gevist mag worden.

Omdat sublitorale mosselbanken nooit droog komen te liggen, is kartering van de precieze contouren veel moeilijke dan in het litoraal. De contouren worden ingeschat op basis van de vangsten per monsterpunt. In de voorjaarsinventarisatie wordt deze kartering sinds 2014 structureel jaarlijks uitgevoerd. Het doel is om de ontwikkeling van arealen in de voor mosselvisserij (en garnalenvisserij) gesloten gebieden te kunnen vergelijken met de gebieden waar nog steeds gevist mag worden ${ }^{45}$.

Omdat de gesloten gebieden juist op plekken zijn gekozen waar zich in het verleden vaker meerjarige mosselbanken bevonden, is het areaal in de gesloten gebieden relatief stabiel. In de open gebieden worden na omvangrijke broedvallen grote arealen aan zaadbanken aangetroffen (zoals in 2017 en 2019). Hiervan verdwijnt echter een groot deel vaak ook al snel weer ${ }^{45}$. Het areaal sublitorale banken laat daardoor in de open gebieden een veel grilliger verloop zien.

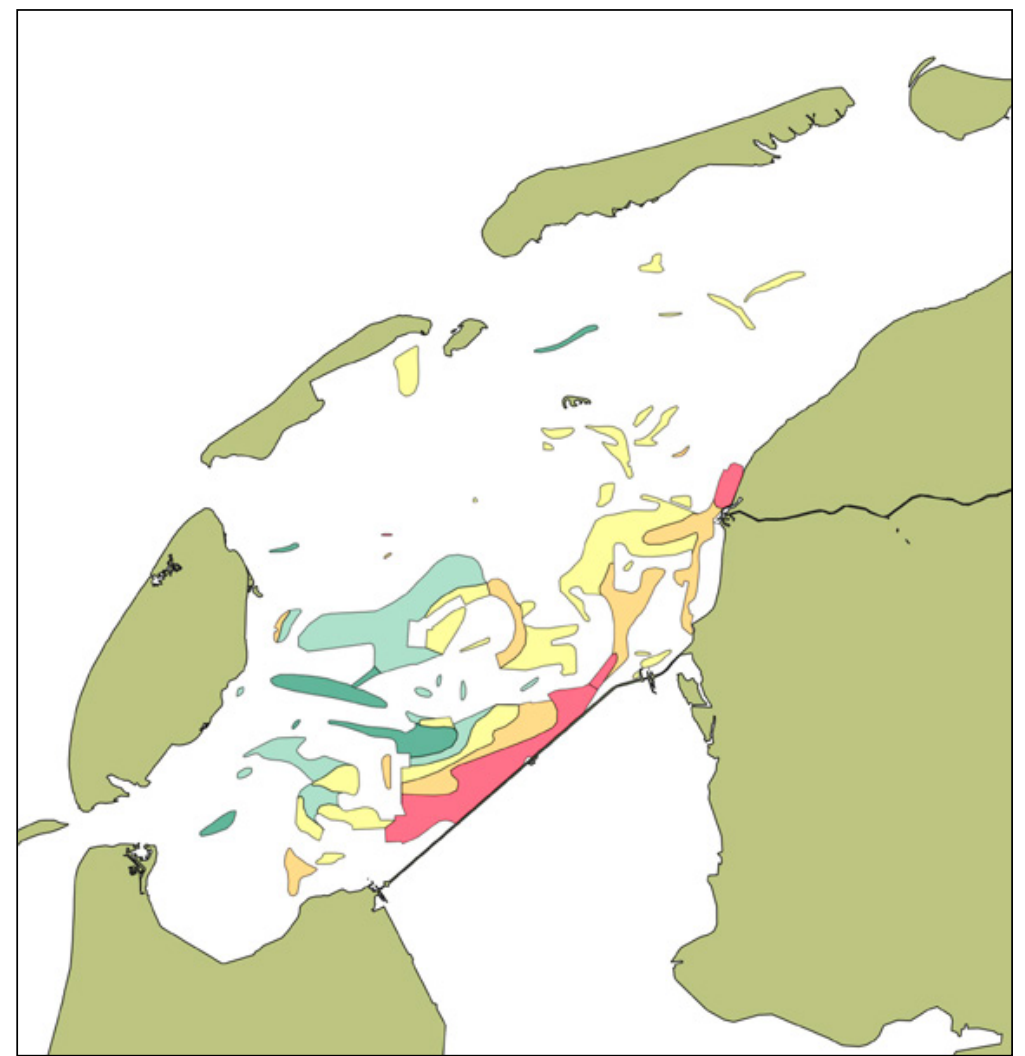

Stabiliteitskaart op basis van ervaring en expert judgement. Groen $=$ klasse $1=$ relatief instabiel; Lichtgroen $=$ klasse $2 ;$ Geel $=$ klasse 3; Oranje $=$ klasse $4 ;$ Rood $=$ klasse $5=$ relatief stabiel. ${ }^{77}$
Wilde

mosselbanken

\section{Beheer}

Rol mosselbanken

Beheermaatregelen

Areaal droogvallend

Ontwikkeling

sublitorale banken

Biodiversiteit

Draagkracht

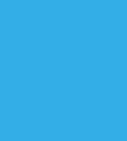

(20) 18 


\section{Waarom zijn wilde mosselbanken belangrijk?}

Wilde mosselbanken spelen een belangrijke rol in het ecosysteem. Ze vormen structuren en leefruimte voor andere soorten, die op en tussen de mosselen leven ${ }^{32-34}$. Denk bijvoorbeeld aan andere schelpdieren, krabbetjes, zeesterren, sponzen, anemonen, pokken en wormen. Dit worden ook wel geassocieerde soorten genoemd. Ook leveren wilde mosselbanken voedsel voor schelpdieretende vogels en vogels die leven van organismen die in de mosselbanken voorkomen ${ }^{35-37}$. Mosselbanken zijn dus van groot belang voor de biodiversiteit, en vormen een belangrijke schakel in het voedselweb ${ }^{6,38}$. Mosselen op kweekpercelen vervullen grotendeels dezelfde rol als mosselen op wilde banken ${ }^{32}$.

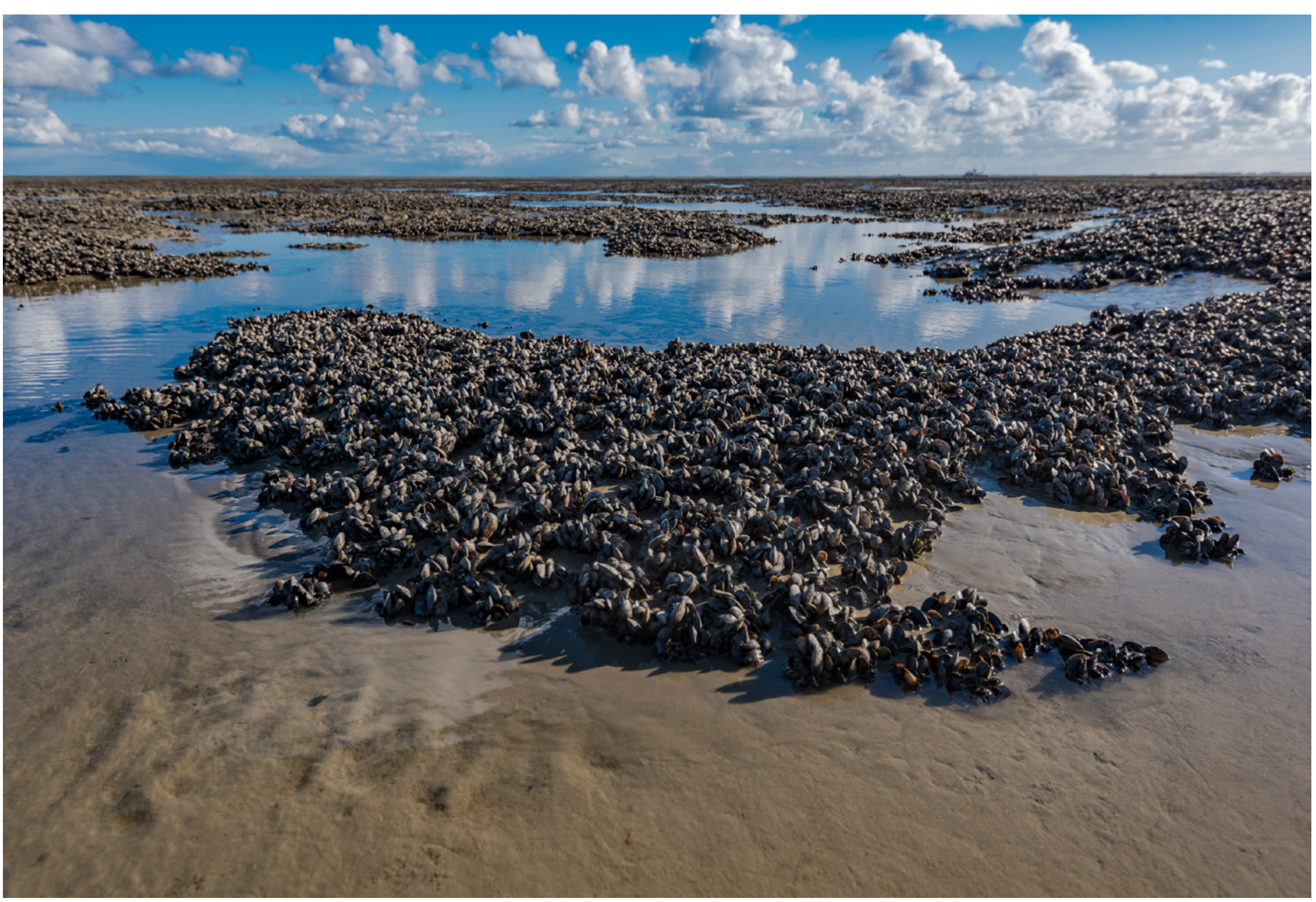

\section{Biodiversiteit}

Rol mosselbanken

Areaal droogvallend

Ontwikkeling

sublitorale banken

Samenstelling

bodemdieren

Visserijeffecten

bodemdieren

Gebiedssluiting

sublitoraal

Vogels

Draagkracht

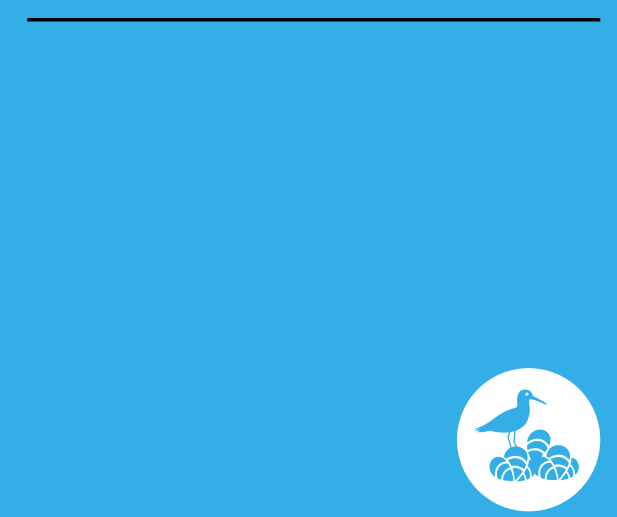




\section{Hoe ontwikkelt het areaal droogvallende wilde mosselbanken zich?}

Mosselbanken ontstaan door de jaren heen vaak op dezelfde plekken ${ }^{46,47}$. Vooral op de meer beschutte locaties kunnen ze meerdere jaren blijven bestaan. Dit komt door een combinatie van beschutting tegen wegspoelen en tussentijdse nieuwe zaadval in dezelfde bank ${ }^{6,48}$

In de Nederlandse Waddenzee ligt jaarlijks tussen de 1500 en 3900 hectare aan droogvallende mosselbanken ${ }^{14}$; in het sublitoraal tussen de 600 en 2800 hectare ${ }^{42,45}$. Tussen jaren kan dit areaal sterk verschillen ${ }^{14}$. Dit komt aan de ene kant doordat in sommige jaren een massale zaadval optreedt.

Aan de andere kant is de overlevingskans van een mosselbank laag ${ }^{49}$. Op de droogvallende platen kunnen door stormen en golfwerking gedurende de winter veel mosselbanken verdwijnen ${ }^{49,50}$. In het sublitoraal spelen stormen waarschijnlijk ook een rol, en verdwijnen daarnaast veel mosselbanken door zeesterren ${ }^{6,51,52}$. Zeesterren kunnen massaal voorkomen op mosselbanken en deze helemaal opeten ${ }^{53}$.

Ieder jaar zijn er veel mossellarven in het water te vinden. Maar het is niet zo dat ieder jaar een succesvolle zaadval kent. Daarvoor moeten meerdere omstandigheden gunstig zijn, zoals voldoende voedsel, een gunstige temperatuur en weinig roofdieren ${ }^{6}$. Vervolgens is de kans dat een nieuwe zaadbank de eerste winter overleeft, klein. Van de droogvallende banken verdwijnt al tijdens de eerste winter gemiddeld $40 \%{ }^{6}$. Hiervan overleeft uiteindelijk ongeveer $15 \%$ tot een leeftijd van 5 jaar. Daarna worden de kansen op overleving groter ${ }^{42}$. Banken die de eerste winter hebben overleefd, leven daarna nog gemiddeld 3 tot 4 jaar ${ }^{42}$. Ter vergelijking: de overlevingskansen van mosselbanken in het sublitoraal zijn kleiner. Van de sublitorale banken overleeft ongeveer $27 \%$ de eerste winter. Er zijn daarbij geen verschillen tussen beviste en onbeviste banken ${ }^{44}$. Sublitorale banken die de eerste winter hebben overleefd, leven daarna nog

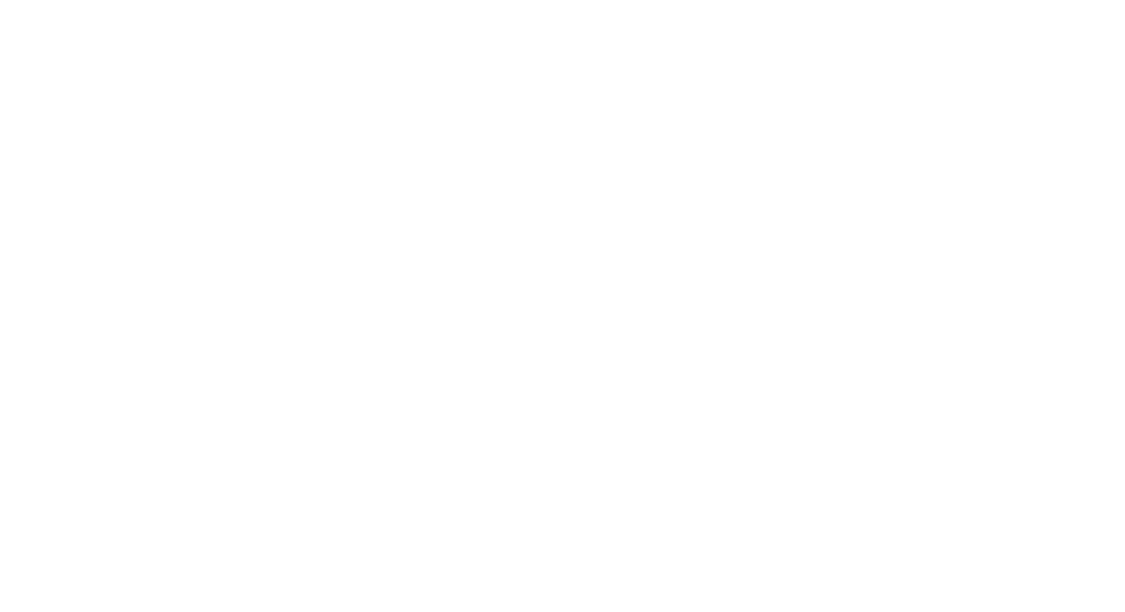

Areaal litorale mosselbanken Waddenzee 1995-2018.

Brongegevens: Wageningen Marine Research.

gemiddeld 2 tot 3 jaar. Ook in het sublitoraal neemt de overlevingskans toe na de eerste vijf jaar ${ }^{54}$. In het sublitoraal is de overleving van mosselbanken hoger in gebieden met een laag zoutgehalte, waarschijnlijk omdat daar minder zeesterren voorkomen ${ }^{31,52}$

In de Waddenzee komen sinds 2002 ook Japanse oesters voor in de mosselbanken. Tegenwoordig bestaat tussen de $33 \%$ en $69 \%$ van de litorale banken uit pure mosselbanken. De rest zijn gemengde banken waarin ook Japanse oesters voorkomen ${ }^{14}$. Japanse oesters hebben een stabiliserende werking en vergroten de overlevingskansen van een litorale mosselbank ${ }^{42}$. Dit kan ten koste gaan van de beschikbaarheid van mosselen als voedselbron voor vogels zoals de scholekster ${ }^{55,56}$.

In de Oosterschelde worden al decennia lang geen wilde mosselbanken aangetroffen, maar komen mosselen wel voor in Japanse oesterbanken ${ }^{14}$.
Beheer

\section{Biodiversiteit}

Rol mosselbanken

\section{Areaal droogvallend}

Ontwikkeling sublitorale banken

\section{Samenstelling}

bodemdieren

Visserijeffecten bodemdieren

Gebiedssluiting sublitoraal

\section{Vogels}

\section{Draagkracht}
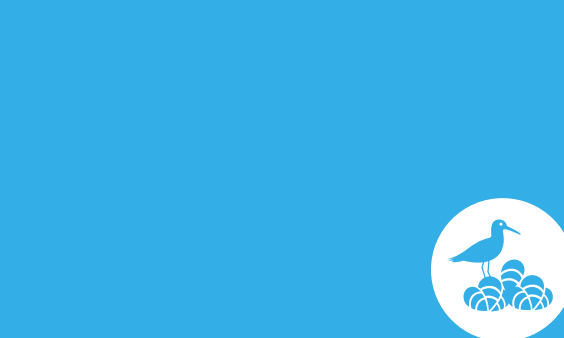


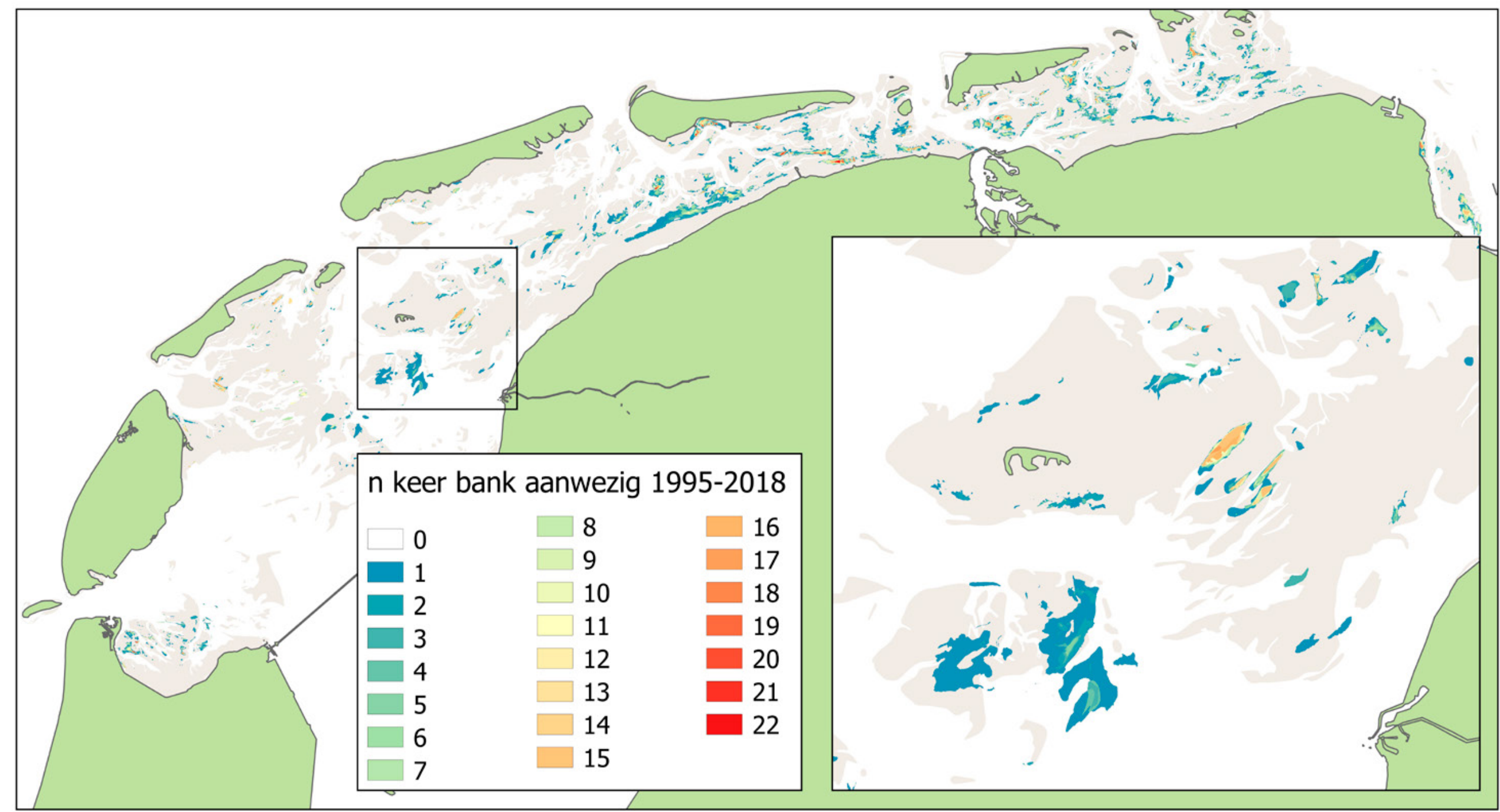

Areaal litorale mosselbanken Waddenzee 1995-2018. Brongegevens: Wageningen Marine Research.

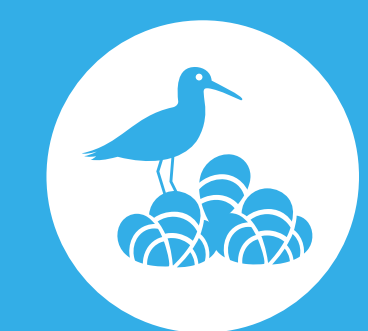

Wilde

mosselbanken

\section{Beheer}

\section{Biodiversiteit}

Rol mosselbanken

\section{Areaal droogvallend}

Ontwikkeling sublitorale banken

Samenstelling bodemdieren

Visserijeffecten bodemdieren

Gebiedssluiting sublitoraal

\section{Vogels}

\section{Draagkracht}

\section{(1)}




\section{Hoe ontwikkelt het areaal aan sublitorale mosselbanken zich?}

Sinds 1992 worden mosselen in het sublitoraal van de westelijke Waddenzee jaarlijks tweemaal geïnventariseerd, in het voorjaar en in het najaar ${ }^{13}$. Met deze gegevens worden ieder jaar verspreidingskaarten gemaakt. Uit een vergelijking van de jaarlijkse verspreidingskaarten blijkt in welke gebieden vaak mosselzaad valt, en in welke gebieden dit mosselzaad vaak wel, of juist niet, overleeft. Deze informatie is verwerkt in de zogeheten "ervaringskaart" (stabilititeitskaart). In deze kaart is ook veldexpertise van vissers, visserijkundig ambtenaren en onderzoekers verwerkt. De kaart laat zien in welke gebieden de kans dat mosselzaad de eerste winter overleeft, als hoog of juist laag wordt ingeschat. De kaart wordt gebruikt als basis voor de mosselzaadvisserij in het najaar, wanneer op instabiele banken gevist mag worden.

Omdat sublitorale mosselbanken nooit droog komen te liggen, is kartering van de precieze contouren veel moeilijker dan in het litoraal. De contouren worden ingeschat op basis van de vangsten per monsterpunt. In de voorjaarsinventarisatie wordt deze kartering sinds 2014 structureel jaarlijks uitgevoerd. Het doel is om de ontwikkeling van arealen in de voor mosselvisserij (en garnalenvisserij) gesloten gebieden te kunnen vergelijken met de gebieden waar nog steeds gevist mag worden ${ }^{45}$.

Omdat de gesloten gebieden juist op plekken zijn gekozen waar zich in het verleden vaker meerjarige mosselbanken bevonden, is het areaal in de gesloten gebieden relatief stabiel. In de open gebieden worden na omvangrijke broedvallen grote arealen aan zaadbanken aangetroffen (zoals in 2017 en 2019). Hiervan verdwijnt echter een groot deel vaak ook al snel weer ${ }^{45}$. Het areaal sublitorale banken laat daardoor in de open gebieden een veel grilliger verloop zien.

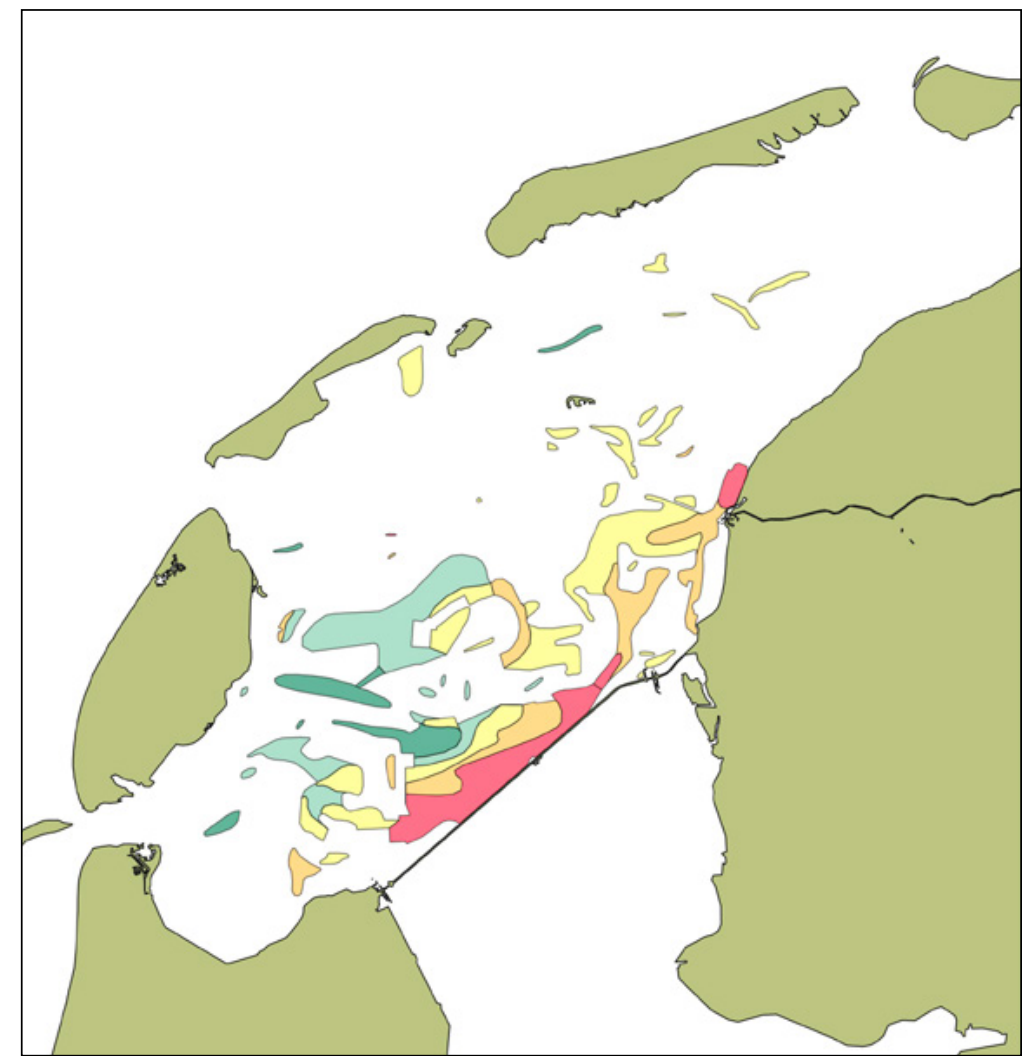

Stabiliteitskaart op basis van ervaring en expert judgement. Groen $=$ klasse $1=$ relatief instabiel; Lichtgroen $=$ klasse $2 ;$ Geel $=$ klasse 3 ; Oranje $=$ klasse $4 ;$ Rood $=$ klasse $5=$ relatief stabiel. ${ }^{77}$
Wilde

mosselbanken

Beheer

\section{Biodiversiteit}

Rol mosselbanken

Areaal droogvallend

Ontwikkeling

sublitorale banken

Samenstelling

bodemdieren

Visserijeffecten

bodemdieren

Gebiedssluiting

sublitoraal

\section{Vogels}

\section{Draagkracht}

\section{(n)}

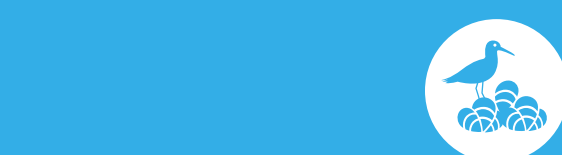




\section{Zijn er verschillen in de bodemdierengemeenschap op wilde mosselbanken en op de kweekpercelen?}

De mosselen op de kweekpercelen spelen grotendeels dezelfde rol als op wilde mosselbanken; ze dragen bij aan een hoge biodiversiteit, verbeteren de waterkwaliteit, en bepalen gezamenlijk de draagkracht voor schelpdieren van het ecosysteem.

De biodiversiteit op mosselkweekpercelen verschilt niet wezenlijk van die op sublitorale mosselbanken. Beide hebben een relatieve hoge biodiversiteit. Op de wilde mosselbanken in het sublitoraal zijn in een grootschalige studie gemiddeld 84 verschillende soorten aangetroffen; op de percelen gemiddeld $102^{32}$. Er zijn twee verklaringen voor het verschil in aantallen soorten. Ten eerste komen wilde banken over het algemeen bij lagere zoutgehaltes voor, terwijl de kweek percelen vooral in gebieden met relatief hoge zoutgehaltes liggen. Het onderzoek laat zien dat de biodiversiteit groter is bij hogere zoutgehaltes. Wanneer wilde banken en kweek- percelen worden vergeleken die wél vlak bij elkaar liggen, dan blijkt juist het aantal soorten in de wilde banken iets hoger te zijn. Ten tweede houden de mosselkwekers de percelen zo veel mogelijk schoon van zeesterren, die mosselen en geassocieerde soorten opeten ${ }^{32}$.

Op de kweekpercelen bestaat een duidelijk verband tussen de mosselen en de biodiversiteit; hoe meer mosselen, hoe meer andere soorten ${ }^{43,57}$. Op de kweekpercelen zijn welis-

waar meer verschillende soorten aanwezig, maar op de wilde banken komen deze geassocieerde soorten juist vaker voor. Het gaat dan vooral over soorten die voorkomen op zacht substraat zoals zanderige bodems (bijvoorbeeld de groene zeeduizendpoot, de strandgaper en het wadslakje). Soorten die juist meer voorkomen op de kweekpercelen zijn o.a. de Amerikaanse zwaardschede, de zeester en mosdiertjes ${ }^{32}$.

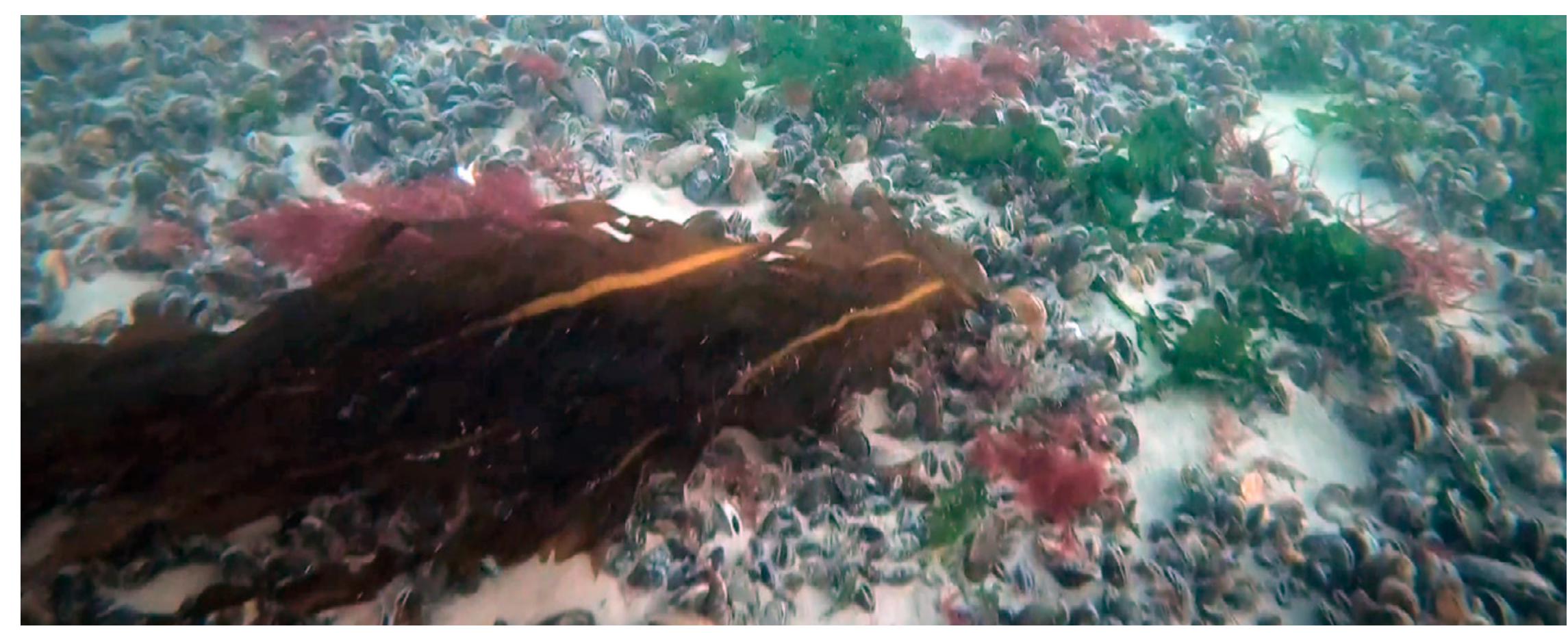

Wilde

mosselbanken

Beheer

\section{Biodiversiteit}

Rol mosselbanken

Areaal droogvallend

Ontwikkeling sublitorale banken

\section{Samenstelling bodemdieren}

Visserijeffecten bodemdieren

Gebiedssluiting sublitoraal

Vogels

Draagkracht

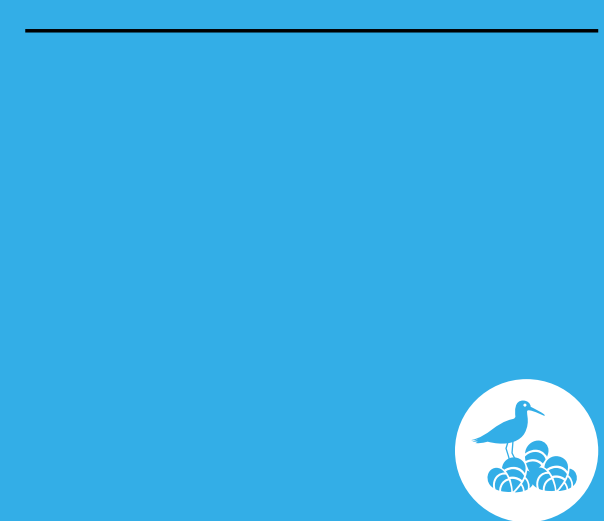




\section{Welke effecten heeft mosselzaadvisserij op de bodemdierengemeenschap?}

De mosselzaadvisserij kan gevolgen hebben voor de biodiversiteit van de Waddenzee, bijvoorbeeld door het wegvissen van een (deel) van de wilde zaadbanken. Tussen 2006 en 2012 zijn beviste delen van een sublitorale mosselbank vergeleken met onbeviste delen (referentiegebieden). Dit onderzoek laat zien dat er vlak na bevissing een negatief effect van de visserij op de sublitorale mosselbanken is. De zaadbanken zijn niet verdwenen, maar direct na de visserij is er wel een lagere dichtheid aan mosselen ${ }^{43,57}$ en aan geassocieerde soorten ${ }^{40,41,44}$. Dat resultaat is geheel volgens verwachting; er is immers gevist.

De mindere hoeveelheid strandkrabben en zeesterren direct na bevissing is te verklaren omdat met het opvissen van het mosselzaad, een belangrijke voedselbron voor deze soorten verdwenen is. Daarnaast worden de krabben en zeesterren opgevist. Het gaat voor deze soorten dus om zowel een indirect als een direct effect van de zaadvisserij. In het geval van anemonen kan de afgenomen dichtheid als een direct effect worden toegeschreven aan de zaadvisserij; zij worden opgevist ${ }^{41}$
Na 1,5 jaar kunnen er geen verschillen meer worden aangetoond tussen de beviste delen binnen een mosselbank en de onbeviste controlegebieden. Het is aannemelijk dat dit komt omdat na de visserij nog steeds voldoende mosselen overblijven om structuur te bieden voor de hernieuwde ontwikkeling van de zaadbanken ${ }^{43,57}$. Het onderzoek laat ook zien dat de variatie in biomassa en voorkomen van geassocieerde soorten, zoals anemonen, in een mosselbank sterk varieert in tijd en onafhankelijk is van menselijke activiteiten. De natuurlijke dynamiek van de Waddenzee speelt hier een grote rol ${ }^{40,44}$.

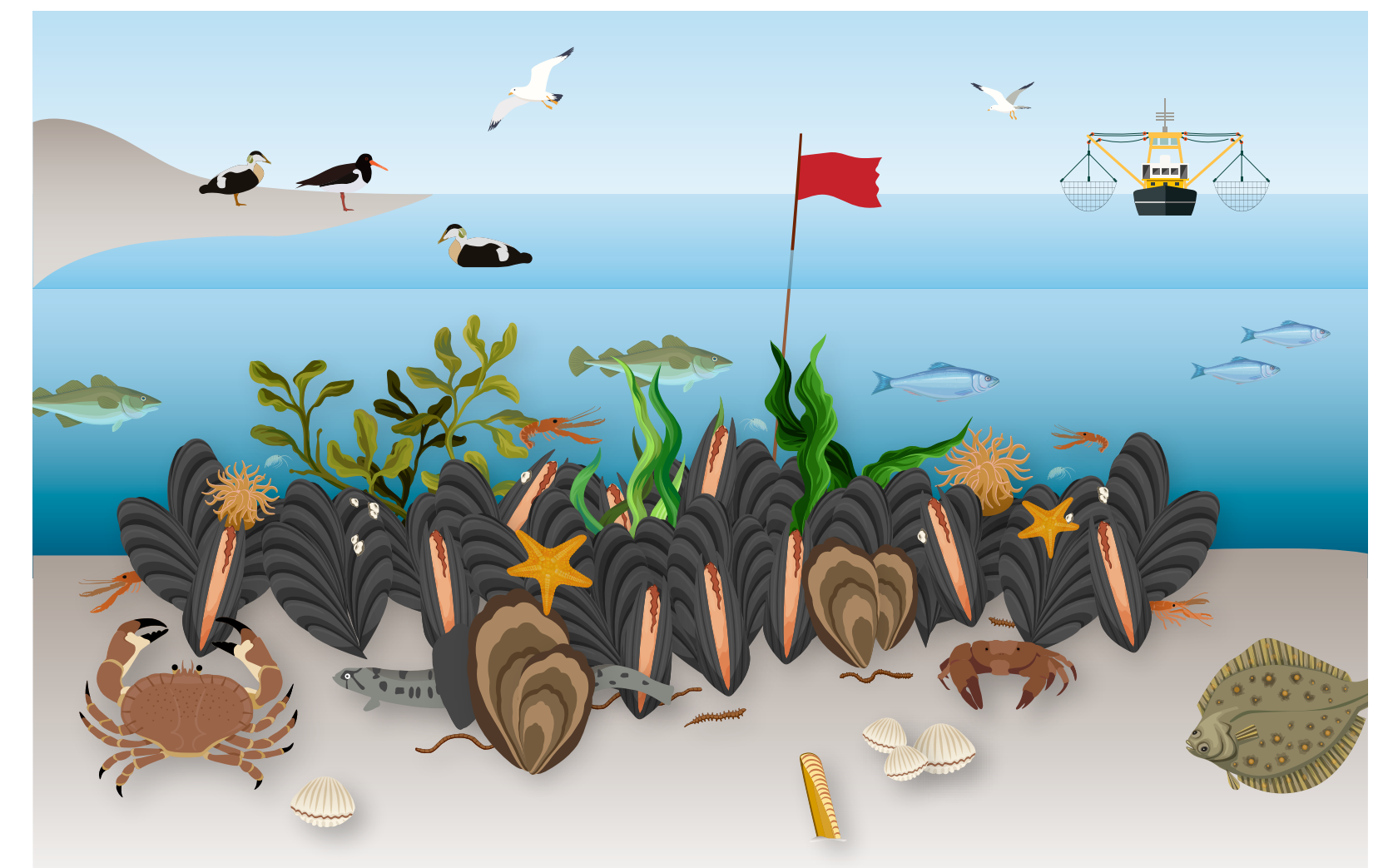

\section{Wilde}

mosselbanken

Beheer

\section{Biodiversiteit}

Rol mosselbanken

Areaal droogvallend

Ontwikkeling sublitorale banken

Samenstelling bodemdieren

\section{Visserijeffecten} bodemdieren

Gebiedssluiting sublitoraal

\section{Vogels}

Draagkracht

\section{。}




\section{Wat zijn de effecten van de sluiting van sublitorale gebieden voor visserij op de bodemdierengemeenschap?}

In de westelijke Waddenzee is sinds 2014 een aantal gebieden gesloten voor de mosselzaad- en de garnalenvisserij. Het doel is om natuurontwikkeling te bevorderen. De ontwikkeling van het areaal sulbitorale mosselbanken en van het bodemleven in de open en de gesloten gebieden wordt daarom jaarlijks gevolgd en vergeleken ${ }^{45}$. Over de eerste vijf jaar van het onderzoek (2015-2019) zijn geen verschillen in ontwikkeling gezien die zouden kunnen wijzen op een veranderde bodemdiergemeenschap door de gebiedssluiting voor mosselzaadvisserij ${ }^{45,48}$. Wel zijn er verschillen gevonden die veroorzaakt worden door de gebiedskeuze. Juist soortenrijke gebieden, waar in het verleden vaak meerjarige mosselbanken werden gevonden, zijn namelijk gesloten ${ }^{45}$. De gesloten en open gebieden waren dus al bij aanvang van het onderzoek verschillend.

De termijn waarop effecten van gebiedssluitingen voor (schelpdier)visserij op bodemdieren optreden, en welke effecten dit zijn, is onderzocht in een literatuurstudie ${ }^{48}$ Directe effecten van visserij, zoals het onttrekken van mosselen en daarmee geassocieerde soorten, zijn alleen op de korte termijn aangetoond ${ }^{40,41,43,44,57}$. De verschillende studies vonden geen bewijs voor lange termijn effecten op bodemdiergemeenschappen. Dat wil niet zeggen dat deze effecten er niet zijn, maar vaak is de onderzoeksopzet beperkt en worden er bijvoorbeeld geen referentiegebieden meegenomen. Ook kan het zijn dat de (grote) natuurlijke dynamiek een grotere rol speelt in het voorkomen van de bodemdiergemeenschap dan de effecten van de visserij. Het is dan niet mogelijk de visserijeffecten aan te tonen. De opzet van het onderzoek naar de effecten van mosselzaadvisserij op de ontwikkeling van de bodemdierengemeenschap $40,41,44,57$ is goed. Visserijeffecten die langer dan 1,5 jaar aanhouden, kunnen echter niet aangetoond worden omdat de natuurlijke dynamiek veel bepalender blijkt.
Er zijn verschillende mogelijke verklaringen voor het uitblijven van een toename in het areaal aan meerjarige mosselbanken in de gesloten gebieden, vijf jaar na sluiting:

1 de visserij heeft geen wezenlijk effect op de ontwikkeling en overleving van meerjarige banken;

2 het effect van de visserij valt in het niet bij de natuurlijke dynamiek;

3 de huidige monitoring is onvoldoende om effecten statistisch aan te kunnen tonen;

4 de onderzoeksperiode is nog te kort om effecten aan te kunnen tonen.

Het onderzoek gaat om de laatste reden de komende jaren verder.
Beheer

\section{Biodiversiteit}

Rol mosselbanken

Areaal droogvallend

Ontwikkeling sublitorale banken

Samenstelling bodemdieren

Visserijeffecten bodemdieren

\section{Gebiedssluiting} sublitoraal

Vogels

Draagkracht

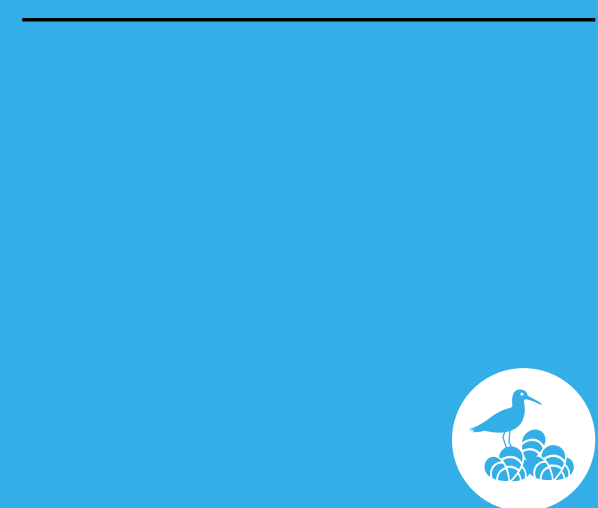




\section{Hoe belangrijk zijn de mosselen op de kweekpercelen als voedselbron voor vogels?}

De Waddenzee is van internationaal belang voor schelpdieretende vogels ${ }^{58}$. Mosselen in de sublitorale gebieden zijn

voor enkele vogelsoorten belangrijk. Duikende eenden, zoals de eidereend en de topper, zijn in staat mosselen van de wilde banken en kweekpercelen in het sublitoraal te eten ${ }^{59}$. Daarbij kan het zo zijn dat soorten die duiken naar vissen die zich tussen de mosselen ophouden, ook baat hebben bij mosselbanken en -percelen, al ontbreken goede telgegevens voor deze vogelsoorten ${ }^{60}$

Het dieet van eidereenden in de Waddenzee kan, bij voldoende aanbod, voor wel $90 \%$ uit mosselen bestaan. Ze vullen dit aan met krabben, kokkels en mesheften.

Verspreidingsonderzoek laat zien dat overwinterende eidereenden een voorkeur hebben om op de kweekpercelen naar voedsel te zoeken ${ }^{37}$. Eidereenden prefereren medium tot grote mosselen in hoge dichtheden. Deze komen in de Waddenzee vooral op de kweekpercelen voor. De kweekmosselen hebben bovendien een betere vlees/schelp verhouding dan 'wilde' mosselen in de getijdezone ${ }^{61,62}$. Eidereenden hebben daarom voordeel bij de aanwezigheid van mosselpercelen ${ }^{29,37}$. Wanneer er minder mosselen op de percelen zijn schakelen ze over naar alternatief voedsel ${ }^{37}$. Ook in de loop van de winter komen de eidereenden weer vaker voor op de wilde mosselbanken. Er zijn twee mogelijke (gecombineerde) verklaringen. De eerste is dat in de winter de kwaliteit van de mosselen op de percelen afneemt en vergelijkbaar wordt met die op de wilde banken ${ }^{59}$. De tweede verklaring is dat er in de loop van de winter steeds meer mosselen van de percelen worden geoogst ${ }^{37}$.

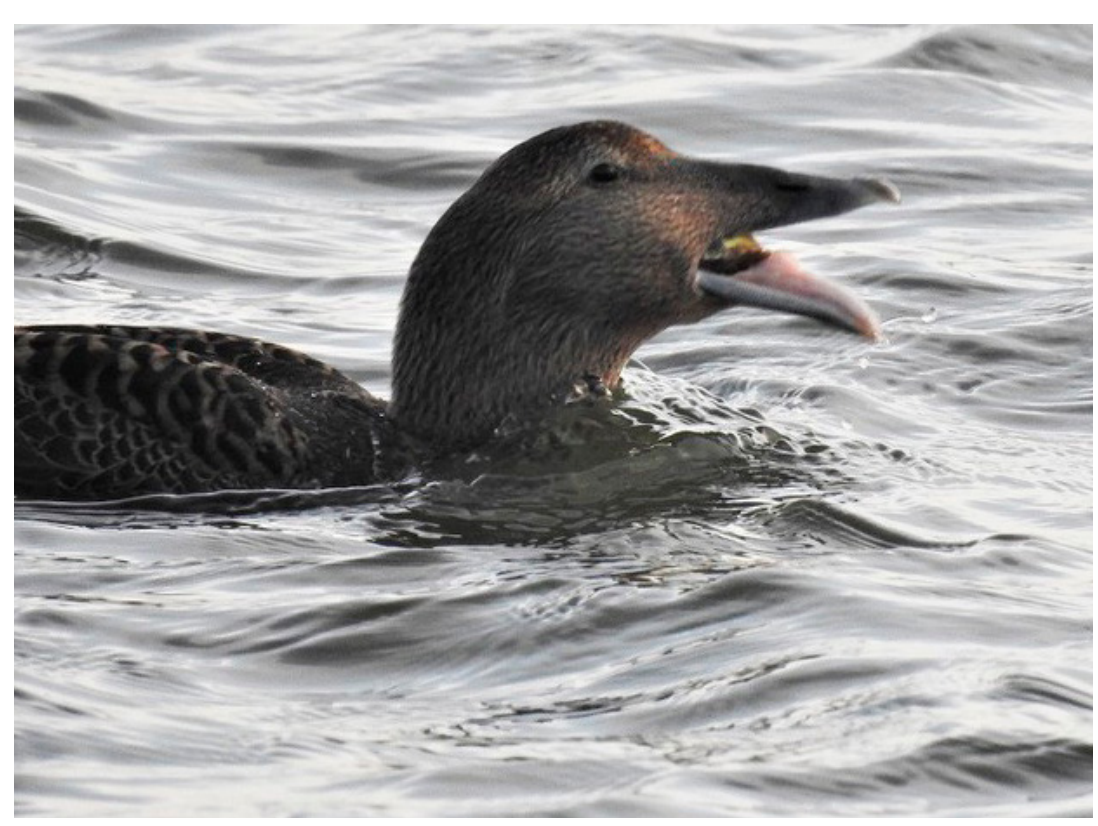

De aantallen overwinterende toppers variëren sterk tussen de jaren. In het Waddengebied worden 's winters rond de 30.000 toppers geteld ${ }^{63}$, vooral voor de Afsluitdijk waar de zoutgehaltes lager zijn ${ }^{58}$. Op de locaties in de Waddenzee waar de toppers voorkomen, zijn nauwelijks kweekpercelen aanwezig ${ }^{59}$. Uit verspreidingsonderzoek blijkt dat toppers meer voorkomen op locaties waar kleinere prooisoorten aanwezig zijn, zoals jonge strandgapers ${ }^{36}$. Mosselen hebben net als strandgapers een relatief hoge verhouding tussen vlees en schelp. Toch wordt er maar een gering verband gevonden tussen de verspreiding van mosselen en de topper. Waarschijnlijk komt dit omdat mosselen met hun byssusdraden trossen vormen. Het kost de topper dan meer tijd en energie om individuele mosselen te consumeren ${ }^{36}$.

\section{Beheer}

\section{Biodiversiteit}

Rol mosselbanken

Areaal droogvallend

Ontwikkeling sublitorale banken

\section{Samenstelling} bodemdieren

Visserijeffecten bodemdieren

Gebiedssluiting sublitoraal

\section{Vogels}

\section{Draagkracht}

\section{.}




\section{Welke invloed heeft mosselkweek op de draagkracht voor schelpdieren?}

Schelpdieren voeden zich door microalgen uit het water te filteren. Wanneer er zo veel micro-algen worden gegeten dat de groei (aanwas) van de algen wordt afgeremd (over-

begrazing), is het schelpdierbestand te groot. De zogenaamde draagkracht van het ecosysteem voor schelpdieren wordt dan overschreden. De schelpdieren kunnen dan niet meer optimaal groeien. Dit kan negatief doorwerken naar soorten die afhankelijk zijn van schelpdieren, zoals vogels. Gekweekte schelpdierbestanden concurreren om voedsel met natuurlijk voorkomende schelpdieren. Een optimaal evenwicht tussen natuur en productie is daarom belangrijk.

Mosselkweek draagt substantieel bij aan de omvang van het totale schelpdierenbestand en kan daarom effect hebben op de draagkracht. In de Oosterschelde vormen de kweek-

mosselen ongeveer $30 \%$ van het totale schelpdierenbestand; in de westelijke Waddenzee is dit ongeveer $20 \%{ }^{71}$. Recent onderzoek laat zien dat de draagkracht van de Oosterschelde en Waddenzee voor schelpdieren momenteel niet onder druk staat ${ }^{71}$.

Voor de Oosterschelde concluderen eerdere studies dat er voor de periode 1995-2009 aanwijzingen voor overbegrazing $z_{i j n}{ }^{72}$. Sindsdien hebben veranderingen plaatsgevonden, zoals een afname van het oesterbestand door de oesterboorder en het herpesvirus. De meest recente inzichten zijn dat het totale schelpdierbestand in de Oosterschelde en daarmee de totale graasdruk (het wegfilteren van voedsel door schelpdieren) van jaar tot jaar varieert. Er zijn geen duidelijke toe- of afnemende trends. Het oesterbestand is weliswaar afgenomen, maar hierdoor is er geen substantiële daling van de graasdruk van het gehele schelpdierbestand. Er zijn geen aanwijzingen dat de huidige bestanden aan schelpdieren inclusief de gekweekte mosselen, op dit moment directe invloed uitoefenen op de productiviteit van het ecosysteem

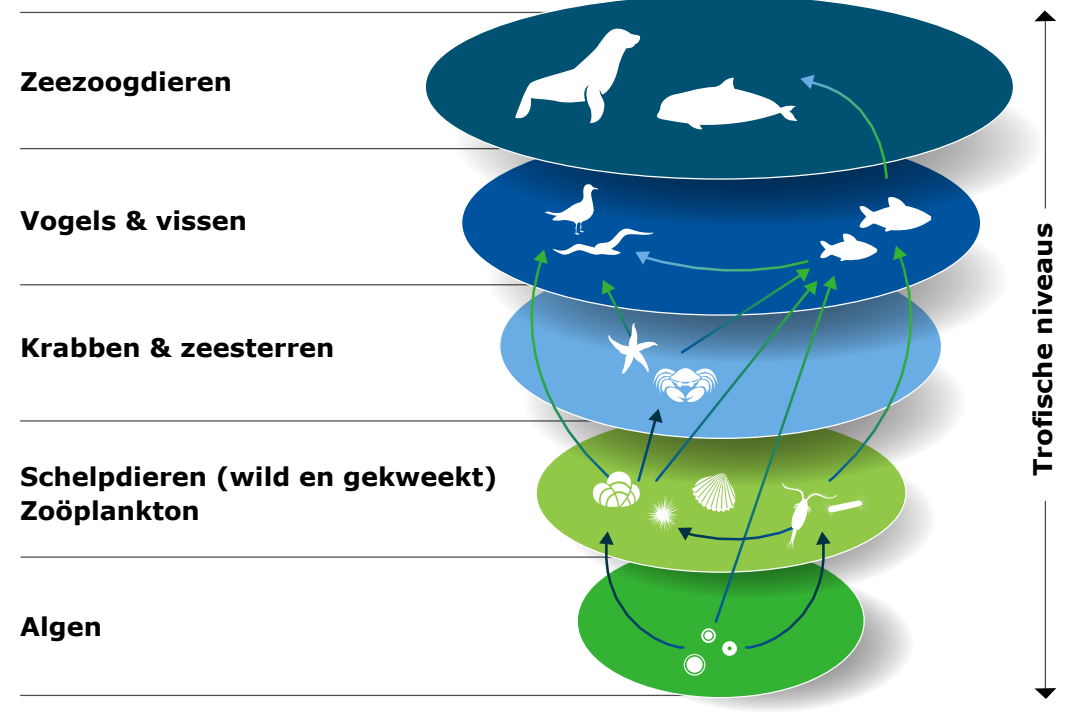

en het actuele voedselaanbod in de Oosterschelde. Meer schelpdieren lijken vooralsnog niet direct tot een lagere micro-algen populatie te leiden ${ }^{71}$. De groei van micro-algen populaties worden naast de begrazing door schelpdieren ('top down') bepaald door de nutriënten toevoer ('bottom up'). Hoe veranderingen in nutriëntenconcentraties de afgelopen jaren de productiviteit beïnvloed hebben, is geen onderdeel van de recente studie.

In de Waddenzee leveren niet de kweekmosselen maar andere wilde schelpdiersoorten, zoals de strandgaper, de grootste bijdrage aan de graasdruk. In de gebieden in de westelijke Waddenzee, waar de kweekpercelen liggen, is het niet waarschijnlijk dat overbegrazing optreedt; ook niet in het Marsdiep waar de (wilde) schelpdierenbestanden en de bijbehorende graasdruk sterk zijn toegenomen ${ }^{71}$. De bevinding dat de draagkracht in de westelijke Waddenzee niet overschreden wordt, komt overeen met een recente studie op Balgzand ${ }^{73}$.

\section{Wilde}

mosselbanken

\section{Beheer}

Biodiversiteit

\section{Draagkracht}

\section{Draagkracht} ecosysteem

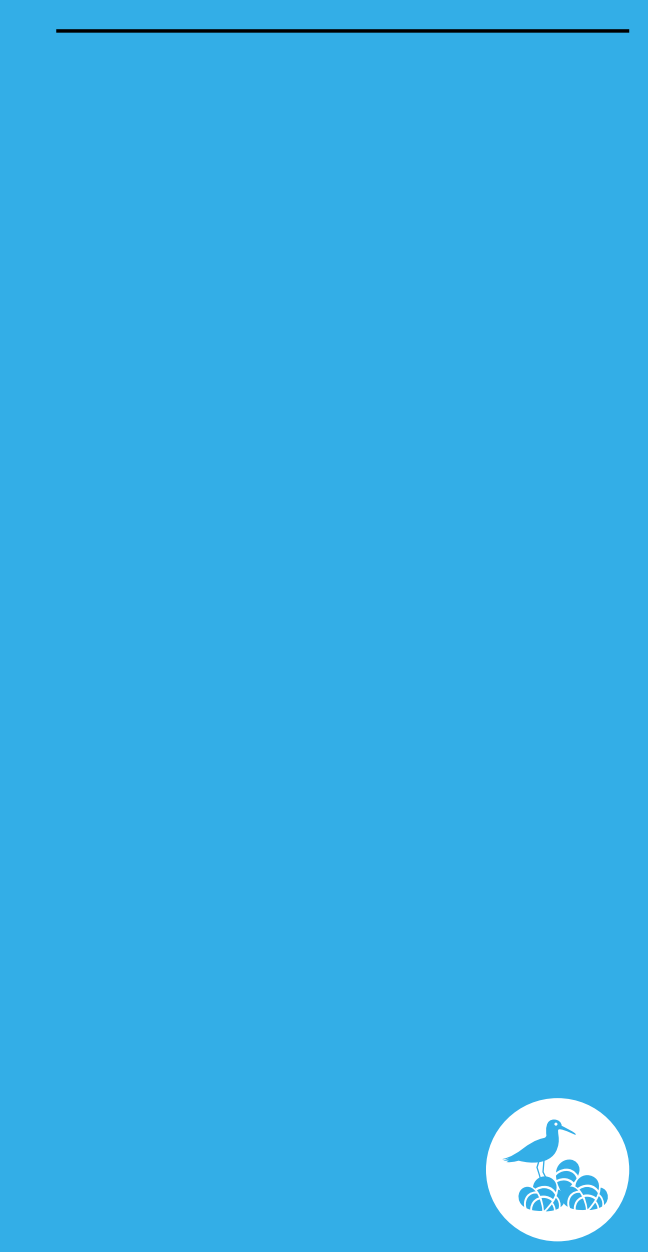




\section{Welke kennisvragen worden nog niet onderzocht?}

Draagkracht:

- Metingen aan zowel de productie van micro-algen als ook gestandaardiseerde metingen voor de mosselkwaliteit (vleesgewicht) in de Waddenzee en Oosterschelde ontbreken. Deze gegevens zijn belangrijk voor het volgen van de ontwikkelingen van de draagkracht voor schelpdieren. $\mathrm{Zij}$ zouden structureel verzameld moeten worden.

- Het is belangrijk de ontwikkelingen rond de draagkracht, met name in het Marsdiep, de komende jaren te blijven volgen. Hiervoor zijn de draagkracht indices van de Aquaculture Stewardship Council een bruikbare referentie.

- De huidige kennis over draagkracht voor schelpdieren heeft betrekking op het hele waterbekken. Hierbinnen kunnen verschillen optreden. Beter inzicht kan helpen in het beheer van deze wateren.

- De strandgaper heeft een groot aandeel in de graasdruk door schelpdieren in de Waddenzee. De snelheid waarmee strandgapers hier voedsel uit het water filteren, is echter niet bekend. Deze wordt geschat. Het bepalen van de filtersnelheid voor deze soort zou een belangrijke bijdrage leveren aan het verminderen van onzekerheden in de draagkrachtbeoordelingen voor schelpdieren.

MZI's:

- In systemen met weinig natuurlijke dynamiek kunnen schelpdierkweekinstallaties in de waterkolom leiden tot lokale voedseltekorten voor schelpdieren (schaduwwerking). Kwekers kunnen dit (deels) voorkomen door rekening te houden met de inrichting van de systemen. Beperkt onderzoek naar het optreden van schaduwwerking in mosselzaadinvanginstallaties (MZI's) in hoogdynamische systemen, zoals de Zeeuwse Delta en Waddenzee, laat zien dat onder sommige omstandigheden lokale voedseltekorten niet zijn uit te sluiten. Een beter inzicht in de factoren die bijdragen aan mogelijke lokale draagkrachteffecten in en rond $M Z I^{\prime} s$, is wenselijk.
- Volgens mosselkwekers kunnen ook mosselkweekpercelen mogelijk schaduwwerking van MZI's ondervinden. Dit is onvoldoende onderzocht, terwijl dit wel onderdeel is van beleidsdiscussies.

- Het is aannemelijk dat MZI's lokaal, gedurende de periode dat de $M Z I^{\prime} s$ in het water liggen, tot een vergroting van de biodiversiteit leiden. $\mathrm{Er}$ is echter geen systematisch onderzoek gedaan naar de effecten van MZI's en het beheer hiervan op de biodiversiteit en de doorwerking naar het ecosysteem.

- Het lijkt onwaarschijnlijk dat op de huidige MZI-locaties (lokaal) veranderingen in bodemstructuur, bodemleven en zuurstofgehaltes ontstaan. Dit zou verder kunnen worden onderzocht.

Kweekpercelen:

- Er zijn geen wezenlijke verschillen tussen de biodiversiteit op wilde mosselbanken en op kweekpercelen. De aanname is echter wel dat de soortensamenstelling op percelen wordt beïnvloed door kweekactiviteiten, doordat een minder complexe mosselmatrix gevormd kan worden. Vergelijkend onderzoek naar welke effecten (aard en omvang) van opvissen, verzaaien, dweilen en oogsten op de geassocieerde soorten van mosselkweekpercelen hebben vergeleken met mosselbanken van dezelfde leeftijd, kan inzicht in deze aanname geven.
Algemeen

Leeswijzer

Samenvatting

Woordenlijst

Inleiding

\section{Kennislacunes}

\section{Literatuurlijst}

\section{Colofon}




\section{Literatuurlijst}

1. Alleway, H. K. et al. The ecosystem services of marine aquaculture: Valuing benefits to people and nature. Bioscience 69, 59-68 (2019).

2. Smaal, A. C., Ferreira, J. G., Grant, J., Petersen, J. K. \& Strand, $\varnothing$. Goods and services of marine bivalves. (Springer Open, 2019).

doi: 10.1007/978-3-319-96776-9.

3. Marine Stewardship Council. Nederlandse mosselen: duurzame landbouw op zee. http://nederlandse-mosselen-verhaal.msc.org/ (2017).

4. MSC. Marine Stewardship Council fisheries standard, version 2.01 (31 August 2018). (2018).

5. Waddensleutels. Waddensleutels: Mosselbanken, fundament van het voedse/web (glossy). http:// docplayer.nl/16970226-Wadden-sleutels-mosselbanken-fundament-van-het-voedselweb-experimenteel-waddenonderzoek-bouwen-van-biobouwers-nieuw-waddennatuurkaart.html (2015).

6. Dankers, N. \& Fey-Hofstede, F. Een zee van mosselen. Handboek ecologie, bescherming, beleid en beheer van mosselbanken in de Waddenzee. (Stichting Anemoon, 2015).

7. LNV. Beleidsbesluit Schelpdiervisserij 2005 - 2020: Ruimte voor een Zilte Oogst. 43 (2004)

8. Smaal, A. C., Van Stralen, M. R., Kersting, K. \& Dankers, N. De gevolgen van experimentele bevissing voor bedekking en omvang van litorale mosselzaadbanken: Een test van de Jan Louw hypothese en van mogelijkheden voor natuurbouw. (2003).

9. Van Stralen, M. R. Passende Beoordeling van de mosselvisserij in het sublitoraal van de Westelijke waddenzee in de periode 2018-2020. (2018).

10. Floor, J. R. et al. Knowledge uncertainties in environmental conflicts: How the mussel fishery controversy in the Dutch Wadden Sea became depoliticised. Env. Polit. 28, 1236-1258 (2019).
11. Minister LNV et al. Convenant transitie mosselsector en natuurherstel Waddenzee. 4 (2008).

12. Minister LNV. Mosselconvenant / MZI-beleid 20212026. Brief aan de Tweede Kamer, 7 december 2020. https://www.parlementairemonitor.nl/9353000/1/ j9vvij5epmj1ey0/vlelk7mmigz9 (2020).

13. WMR. Schelpdiermonitor (dataportal) - Wageningen Marine Research. https://www.wur.nl/nl/artikel/Schelpdiermonitor.htm (2020).

14. Van den Ende, D., Troost, K., Van Asch, M., Perdon, J. \& Van Zweeden, C. Mosselbanken en oesterbanken op droogvallende platen van de Nederlandse zoute getijdenwateren in 2019: bestand en arealen. (St. Wageningen Research, Centrum voor Visserijonderzoek, CVO rapport: 19.022, 2019). doi:10.18174/510066.

15. Stralen, M. R. van \& Troost, K. Inventarisatie van het sublitorale wilde mosselbestand in de westelijke Waddenzee in het voorjaar van 2021. (2021).

16. Stralen, M. R. van \& Van den Ende, D. Inventarisatie van het sublitorale wilde mosselbestand in de westelijke Waddenzee in het najaar van 2020. (2020).

17. Van Oostenbrugge, J. A. E., Steins, N. A., Mol, A., Smith, S. R. \& Turenhout, M. N. W. Mosseltransitie en natuurherstel. (2018). doi:10.18174/446741.

18. Capelle, J. J. \& Stralen, M. R. van. Invang van mosselzaad in MZI's: Resultaten 2019. (2020). doi: $10.18174 / 518888$

19. Capelle, J. J. Literatuuronderzoek naar effecten van de configuratie van MZI-systemen op de productie van mosselzaad. (2018)

20. Wijsman, J. W. M. Effecten MZI-locatie Neeltje Jans op nabij gelegen mosselpercelen. (IMARES WageningenUR Rapport C011/13, 2013)

\section{Algemeen}

\section{Leeswijzer}

Samenvatting

\section{Woordenlijst}

\section{Inleiding}

\section{Kennislacunes}

\section{Literatuurlijst}

\section{Colofon}


21. Ministerie van Economische Zaken. Beleid voor mosselzaadinvanginstallaties (MZI's) 2015-2018. Bijlage behorend bij de brief van de staatssecretaris van Economische Zaken aan de Tweede Kamer, kenmerk DGA-DAD/14203982B (19 januari 2015). 28 (2015).

22. Capelle, J. J., Wijsman, J. W. M., van Stralen, M. R., Herman, P. M. J. \& Smaal, A. C. Effect of seeding density on biomass production in mussel bottom culture. J. Sea Res. 110, 8-15 (2016).

23. Capelle, J. J. Production efficiency of mussel bottom culture. PhD-dissertation. (Wageningen University and Research, 2017). doi:10.18174/404677.

24. Capelle, J. J., Leuchter, L., De Wit, M., Hartog, E. \& Bouma, T. J. Creating a window of opportunity for establishing ecosystem engineers by adding substratum: a case study on mussels. Ecosphere 10, 4 (2019).

25. Christensen, H. T. et al. Aggregation and attachment responses of blue mussels, Mytilus edulis-impact of substrate composition, time scale and source of mussel seed. Aquaculture 435, 245-251 (2015).

26. Capelle, J. J. et al. Onderzoek naar innovatie en rendementsverbetering mosselproductie: INNOPRO 20172019. (Wageningen Marine Research, 2020).

27. T.P. Bult, Stralen, M. R. van, Poelman, M., Steenbergen, J. \& Baars, J. M. D. D. Dynamisch bestandsbeheer van schelpdieren, een verkenning van mogelijkheden en ideeën uit de ODUS visie. (Rijksinstituut voor Visserij Onderzoek, RIVO rapport C010/04, 2004).

28. Mulder, I. et al. Evaluatie nieuwe mosselpercelen: Technische rapportage TO bemonstering vispopulaties 2020. (2020) doi:10.18174/537190.

29. Bult, T. P., Van Stralen, M. R., Brummellhuis, E. \& Baars, J. M. D. D. Mosselvisserij en - kweek in het sublitoraal van de Waddenzee. (2004)

30. Wijsman, J. W. M., Schellekens, T., Van Stralen, M. R., Capelle, J. J. \& Smaal, A. C. Rendement van mosselkweek in de westelijke Waddenzee. (2014).
31. Capelle, J. J., van Stralen, M. R., Wijsman, J. W. M., Herman, P. M. J. \& Smaal, A. C. Population dynamics of subtital mussels (Mytilus edulis) and the impact of cultivation. Aquac. Environ. Interact. 9, 155-168 (2017).

32. Drent, J. \& Dekker, R. How different are subtidal Mytilus edulis $L$. communities of natural mussel beds and mussel culture plots in the western Dutch Wadden Sea? (2013).

33. Buschbaum, C. et al. Mytilid mussels: Global habitat engineers in coastal sediments. Helgol. Mar. Res. 63 47-58 (2009).

34. Dittmann, S. Mussel beds: Amensalism or amelioration for intertidal fauna? Helgoländer Meeresuntersuchungen 44, 35-352 (1990).

35. Leopold, M. F., Kats, R, K. H. \& Ens, B. J. Diet (preferences) of eiders (Somateria mollissima). Wadden Sea Newsl. 25-31 (2001).

36. Cervencl, A. \& Alvarez Fernandez, S. Winter distribution of greater scaup (Aythya marila) in relation to available food resources. J. Sea Res. 73, 41-48 (2012).

37. Cervencl, A. et al. Distribution of wintering common eider (Somateria mollissima) in the Dutch Wadden Sea in relation to available food stocks. Mar. Biol. 162, 153-168 (2014).

38. Christianen, M. J. A. et al. Biodiversity and food web indicators of community recovery in intertidal shellfish reefs. Biol. Conserv. 213, Part, 317-324 (2017).

39. Folmer, E. O. et al. Large-scale spatial dynamics of intertidal mussel (Mytilus edulis L.) bed coverage in the German and Dutch Wadden Sea. Ecosystems 17, 550-566 (2014)

40. Craeymeersch, J. . et al. Impact of mussel seed fishery on subtidal macrozoobenthos in the western Wadden Sea. https://edepot.wur.nl/292179 (2013).

41. Glorius, S. T., Rippen, A. D., Van Stralen, M. R. \& Jansen, J. M. Effecten van mosselzaadvisserij op het bodemleven van de Waddenzee. (2013).

\section{Leeswijzer}

\section{Samenvatting}

\section{Woordenlijst}

\section{Inleiding}

\section{Kennislacunes}

\section{Literatuurlijst}

\section{Colofon}


42. Troost, K., van der Meer, J. \& Stralen, M. R. van. The birth, growth and death of intertidal soft-sediment bivalve beds: No need for large-scale restoration programs in the Dutch Wadden Sea. Ecosystems 22, 1024-1034 (2019).

43. Smaal, A. C., Craeymeersch, J. . \& van Stralen, M. R. The impact of mussel seed fishery on dynamics of wild subtidal mussel beds in the western Wadden Sea, The Netherlands. Netherlands J. Sea Res. 167, (2021).

44. Craeymeersch, J. ., van Stralen, M. R., Meesters, E. \& Smaal, A. C. Impact of mussel seed fishery on subtida macrozoobenthos in the western Wadden Sea. Netherlands J. Sea Res.

45. Troost, K. et al. Ontwikkeling van bodemdieren in de voor mosselzaadvisserij gesloten gebieden in de westelijke Waddenzee - Evaluatie na vier jaar monitoring (2015-2018). (2019) doi:10.18174/473019.

46. Troost, K., Stralen, M. R. van, Van Zweeden, C. \& Brinkman, A. G. Ruimtelijke verspreiding van mosselen en Japanse oesters in de Waddenzee in de periode 1992 -2013. (IMARES WageningenUR Rapport C062/15, 2015).

47. Troost, K., Drent, J., Folmer, E. \& Stralen, M. R. van. Ontwikkeling van schelpdierbestanden op de droogvallende platen van de Waddenzee. 113, 83-88 (2012).

48. Troost, K., Van den Bogaart, L. \& Jansen, H. Effecten van gebiedssluiting voor schelpdiervisserij op ontwikkeling meerjarige mosselbanken en bodemdiergemeenschap. (2019) doi:10.18174/497048.

49. Nehls, G. \& Thiel, M. Large-scale distribution patterns of the mussel (Mytilus edulis) in the Wadden Sea of Schleswig-Holstein: do storms structure the ecosystem? Netherlands J. Sea Res. 31, 181-187 (1993).

50. Donker, J. J. A., van der Vegt, M. \& Hoekstra, P. Erosion of an intertidal mussel bed by ice- and wave-action. Cont. Shelf Res. 106, 60-69 (2015).

51. Agüera García, A. The role of starfish (Asterias rubens L.) predation in blue mussel (Mytilus edulis L.) seedbed stability. (Wageningen University and Research, PhD disseration, 2015).
52. Troost, K., van der Meer, J. \& Stralen, M. R. van. The birth, growth and death of intertidal soft-sediment bivalve beds: No need for large-scale restoration programs in the Dutch Wadden Sea. Ecosystems 22, 1024-1034 (2019).

53. Agüera García, A. et al. Winter feeding activity of the common starfish (Asterias rubens L.): The role of temperature and shading. J. Sea Res. 72, 106-112 (2012).

54. Troost, K., van der Meer, J. \& van Stralen, M. R. van. The birth, growth and death of subtidal mussel beds. J. of Sea Res., under review.

55. Scheiffart, G., Ens, B. J. \& Schmidt, A. What will happen to birds when Pacific Oysters take over the mussel beds in the Wadden Sea? Wadden Sea Newsl. 33 10-14 (2007).

56. Waser, A. M. et al. Impact on bird fauna of a non-native oyster expanding into blue mussel beds in the Dutch Wadden Sea. Biol. Conserv. 202, 39-49 (2016).

57. Stralen, M. R. van et al. Het mosselbestand op de PRODUS-vakken en de effecten van de visserij daarop. (2013).

58. Van der Jeugd, H., Ens, B. J., Versluijs, M. \& Schekkerman, H. Geïntegreerde monitoring van vogels van de Nederlandse Waddenzee. Vogeltrekstation rapport 2014-01. Vogeltrekstation, Wageningen;CAPS-rapport 2014-01; Sovon-rapport 2014/18, Sovon Vogelonderzoek Nederland, Nijmegen. https://www.sovon.nl/sites/ default/files/doc/Rap_2014-18_Geïntegreerde_monitoring_Wadden.pdf (2014).

59. Jansen, H. M. Het belang van sublitorale mosselen als voedselbron in de westelijke Waddenzee. (2019) doi:10.18174/474613.

60. Schekkerman, $\mathrm{H}$. et al. Overwinterende watervogels op het diepere water van de Waddenzee: Een ruwe aantalsschatting. Limosa 88, 136-144 (2015).

61. Kats, R. K. H. Common Eiders Somateria mollissima in the Netherlands. The rise and fall of breeding and wintering populations in relation to the stocks of shellfish. (2007).
Algemeen

\section{Leeswijzer}

Samenvatting

\section{Woordenlijst}

\section{Inleiding}

\section{Kennislacunes}

\section{Literatuurlijst}

\section{Colofon}


62. Steenbergen, J., Breen, V. P. \& Jol, J. LNV bestek mosselen en eidereenden Deelproject 3 : een vergelijking van de kwaliteit van mosselen op percelen en in het wild. https://edepot.wur.nl/37357.

63. Lilipaly, S. J., Arts, F. A., Sluijter, M. \& Wolf, P. A. Midwintertelling van zee-eenden in de Waddenzee en Nederlandse kustwateren in november 2017 en januar 2018. (Rijkswaterstaat, rapport BM 18.24, DPM Rapportnr. 2018-05., 2018).

64. Callier, M. D. et al. Attraction and repulsion of mobile wild organisms to finfish and shellfish aquaculture: a review. Rev. Aquac. 10, 924-949 (2018).

65. Wijsman, J. W. M., Engelberts, A. G. M. \& Van den Brink, A. Flora en fauna geassocieerd met mosselpopulaties in de Oosterschelde en Voordelta in 2009. https://edepot.wur.nl/142999 (2010).

66. Kamermans, P. \& De Mesel, I. Meerjarige effectmetingen aan MZI's in de westelijke Waddenzee en Oosterschelde, Deelproject 2: Depositie van organisch materiaal van MZI-mosselen op de bodem in Waddenzee en Oosterschelde 2009. (IMARES WageningenUR Rapport C081/10, 2010).

67. Kamermans, P., Smit, C., Wijsman, J. W. M. \& Smaal, A. C. Meerjarige effect- en productiemetingen aan MZI's in de Westelijke Waddenzee, Oosterschelde en Voordelta: samenvattend eindrapport. https://edepot. wur.nl/312852 (2014).

68. Nizzoli, D., Welsh, D. T., Bartoli, M. \& Viaroli, P. Impacts of mussel (Mytilus galloprovincialis) farming on oxygen consumption and nutrient recycling in a eutrophic coastal lagoon. Hydrobiologia 550, 198 (2005).

69. Jansen, H. M. \& Capelle, J. J. Effecten van mosselk week op sediment-dynamiek in de Waddenzee: Uitgebreide samenvatting van het rapport "The effect of mussel farming on sediment dynamics in the Wadden Sea - case studies evaluating the local effects of mussel seed fisheries and mussel ha. (2018) doi: $10.18174 / 454789$
70. Van Duren, L. A. et al. Verkenning Slibhuishouding Waddenzee: Een samenvatting van twee jaar modelleren en kennis verwerven. (Deltares, 2015).

71. Jansen, H., Kamermans, P., Glorius, S. \& Van Asch, M. Draagkracht van de Oosterschelde en westelijke Waddenzee voor schelpdieren: Evaluatie van veranderingen in de voedselcondities en schelpdierbestanden in relatie tot de mosselkweek in de periode 1990-2016. (2019) doi: $10.18174 / 504079$

72. Smaal, A. C., Schellekens, T., Van Stralen, M. R. \& Kromkamp, J. C. Decrease of the carrying capacity of the Oosterschelde estuary (SW Delta, NL) for bivalve filter feeders due to overgrazing? Aquaculture 10 28-34 (2013).

73. Beukema, J. J. \& Dekker, R. The carrying capacity of a tidal flat area for suspension-feeding bivalves. Mar. Ecolology Prog. Ser. 629, 55-65 (2019).

74. Saurel, C., Petersen, J. K., Wiles, P. J. \& Kaiser, M. J. Turbulent mixing limits mussel feeding: Direct estimates of feeding rate and vertical diffusivity. Mar. Ecol. Prog. Ser. 485, 105-121 (2013).

75. van Duren, L. A., Herman, P. M. J., Sandee, A. J. J. \& Heip, C. H. R. Effects of mussel filtering activity on boundary layer structure. Netherlands J. Sea Res. 3-14 (2006).

76. Kamermans, P., Brummellhuis, E. \& Van Gool, A. C. M. MZI-mosselgewicht als indicator van voedselomstandigheden. https://edepot.wur.nl/301438 (2014).

77. Smaal, A.C., Brinkman, A.G., Schellekens, T., Jansen, J., Aguëra García, A. \& Van Stralen, M.R. Ontwikkeling en stabiliteit van sublitorale mosselbanken, samenvattend eindrapport. https://edepot.wur.nl/300655 (2014).

\section{Algemeen}

\section{Leeswijzer}

\section{Samenvatting}

\section{Woordenlijst}

\section{Inleiding}

\section{Kennislacunes}

\section{Literatuurlijst}

\section{Colofon}




\section{Colofon}

\section{Redactie}

Algemeen

Nathalie Steins, Henrice Jansen, Karin Troost \& Jacob Capelle

Versie 11 oktober 2021

\section{Foto's}

Jannes Aalders (Waarneming.nl) (p31, p48), Jacob Capelle (p12, p17, p18, p19, p27, p29,

p35, p45), Yoeri van Es (p1, p10, p36, p41), Lando Nieuwenhuize (p22), Rob Oosterling (p26),

Karin Troost (p6, p21, p37).

\section{Illustraties}

Wageningen University \& Research, Communication Services (p8, p13, p24, p33, p46, p49)

\section{Vormgeving}

Wageningen University \& Research, Communication Services

\section{Met dank aan}

Lisanne van den Bogaard, Mardik Leopold en Jeroen Wijsman (Wageningen Marine Research),

Marnix van Stralen (Bureau MarinX), Aad Smaal (Wageningen University \& Research),

Cora Seip (Navis Advies BV).

\section{(C) Wageningen Marine Research, 2021}

Deze publicatie is onderdeel van het project Schelpdieren, duurzaam en gezond

(BO-65-004-001) met financiële steun vanuit de kennis- en innovatieagenda landbouw

water, voedsel van het ministerie van LNV.

DOI: $10.18174 / 553848$

https://doi.org/10.18174/553848

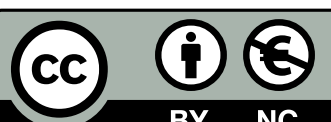

C2021 Wageningen Marine Research. Dit werk is gelicentieerd onder de Creative Commons CC-BY-NC licentie. Zie voor de licentievoorwaarden: https://creativecommons.org/licenses/by-nc/4.0/legalcode.nl

\section{Leeswijzer}

\section{Samenvatting}

\section{Woordenlijst}

\section{Inleiding}

\section{Kennislacunes}

\section{Literatuurlijst}

\section{Colofon}

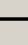

